\title{
THE DISCIPLINARY EFFECT OF SUBORDINATED DEBT ON BANK RISK TAKING
}

by

TU CAM NGUYEN

\author{
A DISSERTATION \\ Presented to the Department of Finance \\ and the Graduate School of the University of Oregon \\ in partial fulfillment of the requirements \\ for the degree of \\ Doctor of Philosophy
}

September 2011 


\section{DISSERTATION APPROVAL PAGE}

Student: Tu Cam Nguyen

Title: The Disciplinary Effect of Subordinated Debt on Bank Risk Taking

This dissertation has been accepted and approved in partial fulfillment of the requirements for the Doctor of Philosophy degree in the Department of Finance by:

Wayne Mikkelson

Chairperson

Ekkehart Boehmer Member

Diane Del Guercio Member

Wesley Wilson

Outside Member

and

Kimberly Andrews Espy Vice President for Research \& Innovation/Dean of the Graduate School

Original approval signatures are on file with the University of Oregon Graduate School.

Degree awarded September 2011 
(C) 2011 Tu Cam Nguyen 


\section{DISSERTATION ABSTRACT}

Tu Cam Nguyen

Doctor of Philosophy

Department of Finance

September 2011

Title: The Disciplinary Effect of Subordinated Debt on Bank Risk Taking

Approved:

\section{Dr. Wayne Mikkelson}

Using data for publicly listed commercial banks and bank holding companies around the world, I investigate the market discipline effect of subordinated debt on banking firm risk taking in the period 2002-2008. In addition, I examine whether this effect depends on national bank regulations and legal and institutional conditions. I provide evidence that subordinated debt has a mitigating effect on banking firm risk taking. Further, the results suggest a threshold level of national bank regulations and economic development above which subordinated debt mitigates risk taking. Overall, the evidence supports the efficacy of proposals calling for increased use of subordinated debt in banking firms. 


\section{CURRICULUM VITAE}

NAME OF AUTHOR: Tu Cam Nguyen

\section{GRADUATE AND UNDERGRADUATE SCHOOLS ATTENDED:}

University of Oregon, Eugene

University of Houston - Clear Lake, Houston, Texas

Belorussian State Agricultural Academy, Mogilev Region, Belarus

\section{DEGREES AWARDED:}

Doctor of Philosophy, Finance, 2011, University of Oregon Master of Science, Finance, 2005, University of Houston - Clear Lake Master of Science (Bachelor of Science), Economics, 1995, Belorussian State Agricultural Academy

AREAS OF SPECIAL INTEREST:

Empirical Corporate Finance

Corporate Governance

Finance and Growth

\section{PROFESSIONAL EXPERIENCE:}

Economist, Vietnam National Chemical Corporation, Hochiminh City, Vietnam, 1996-2001

Instructor, Teaching Assistant, Research Assistant, Department of Finance, University of Oregon, Eugene, 2006-2011

GRANTS, AWARDS, AND HONORS:

Graduate Teaching Fellowship, Finance, University of Oregon, 2006-2011

Hopewell/Racette Scholarship, Finance, University of Oregon, 2007, 2009, and 2010

Scholarship, University of Houston - Clear Lake, 2004 
Diploma with Honors, Belorussian State Agricultural Academy, 1995

Full Vietnam’s Government Scholarship, 1990-1995 


\section{ACKNOWLEDGMENTS}

I am grateful to my dissertation committee, Wayne Mikkelson (Committee Chair), Diane Del Guercio, Ekkehart Boehmer, and Wesley Wilson, for their guidance and support. I also wish to thank Roberto Gutierrez, Chung-Shin Liu, and Larry Wall for

helpful comments and suggestions. I gratefully acknowledge financial support from the University of Oregon. 


\section{TABLE OF CONTENTS}

Chapter

Page

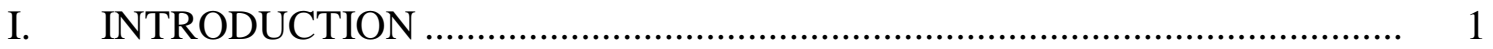

II. CHARACTERISITICS OF SUBORDINATED DEBT AND ITS

RELATION WITH BANKING FIRM RISK TAKING ............................... 4

2.1. Regulatory Treatment of Banking Firms' Subordinated Debt ............ 5

2.2. Subordinated Debt as a Market Discipline Instrument ...................... 6

2.3. Empirical and Theoretical Studies on the Relation Between Subordinated Debt and Bank Risk Taking ..................................... 9

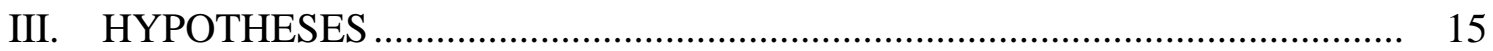

IV. DATA AND METHODOLOGY ......................................................... 17

4.1. Variable descriptions ................................................................ 17

4.1.1. Measuring Subordinated Debt ......................................... 17

4.1.2. Measuring Bank Risk Taking ................................................ 18

4.1.3. Bank-level Control Variables .................................................. 20

4.1.4. Country-level Control Variables.......................................... 21

4.2. Methodology ..................................................................... 23

4.2.1. Main Regression Specification .......................................... 23

4.2.2. Econometric Issues ......................................................... 24

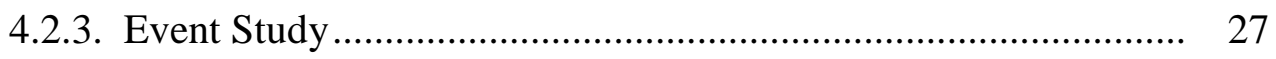

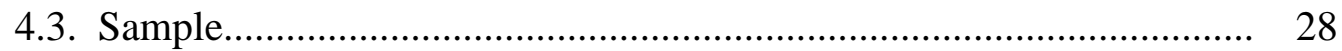

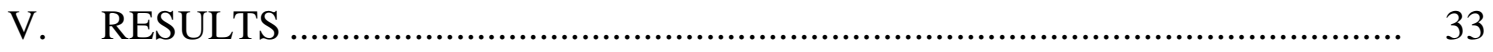

5.1. Regression Analysis............................................................... 33 
5.1.1. Using Ratio of Subordinated Debt to Total Risk-weighted Assets

5.1.2. Using Ratio of Subordinated Debt to Total Liabilities

5.1.3. Sample Selection................................................................... 35

5.1.4. Additional Robustness Checks ……………………................... 35

5.1.5. Alternative Measures of Bank Risk Taking............................... 37

5.1.6. The Impact of Changes in Subordinated Debt on Changes in Bank Risk Taking over the Same Time Period

5.1.7. Other Uninsured Liabilities........................................................ 39

5.1.8. Bank-level Corporate Governance............................................... 40

5.1.9. When Subordinated Debt Is Not Expected to Exert Market Discipline Effects ....................................................................... 42

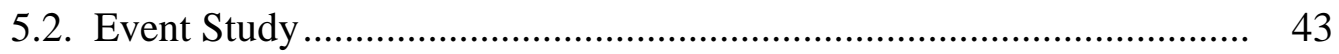

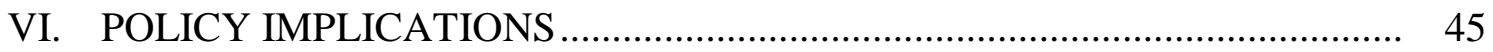

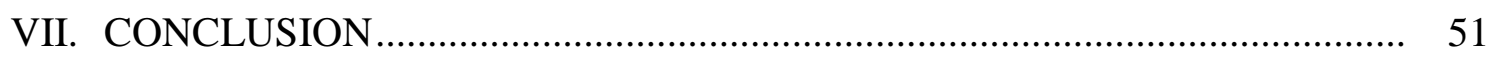

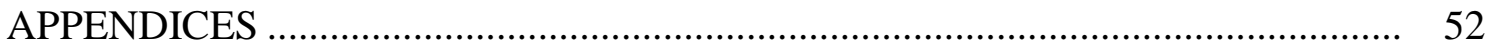

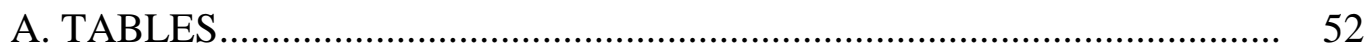

B. SUPPLEMENTAL TABLES ........................................................... 86

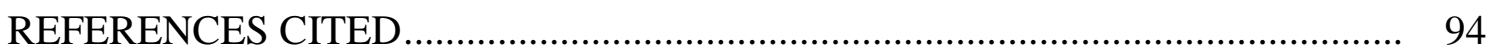




\section{LIST OF TABLES}

Table

Page

I. Variable Definition and Sources ....................................................... 52

II. Summary Statistics................................................................... 57

III. Subordinated Debt and Banks' Future Risk Taking .................................. 59

IV. Impact of Bank Regulations and Economic Development on the Relation Between Subordinated Debt and Banks' Future Risk Taking...................... 60

V. Relation Between Subordinated Debt and Banks' Future Risk Taking Sample Not Subject to Sample Selection................................................. 64

VI. Assessing Sample Selection........................................................... 65

VII. Effect of Subordinated Debt on Bank Risk Taking During the Crisis Period

VIII. Relation Between Subordinated Debt and Banks' Future Risk Taking Reduced Sample

IX. Relation Between Subordinated Debt and Banks' Future Risk Taking Weighted Estimation.

X. Alternative Measures of Bank Risk Taking .......................................... 70

XI. The Impact of Changes on Subordinated Debt on Changes in Bank Risk Taking

XII. Other Uninsured Debt .................................................................. 73

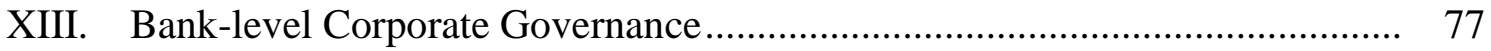

XIV. When Subordinated Debt Is Not Expected to Exert Market Discipline Effects

XV. Impact on Risk Taking for Banking Firms That First Issue Subordinated Debt 


\section{CHAPTER I}

\section{INTRODUCTION}

In this study, I examine whether subordinated debt mitigates bank risk taking and whether national bank regulations and economic development affect the relation between subordinated debt and bank risk taking. My study is motivated by policy considerations. It is evidenced from recent financial turmoil that excessive risk taking behavior of individual banks could expose the whole banking and financial system to systemic risk. Banking crises, in turn, have been shown by Dell' Ariccia et al. (2008), Reinhart and Rogoff (2008), Tong and Wei (2008) to have independent negative effects on the real economy. Hence, there is an increased call for more market discipline on banking firms. Subordinated debt has been widely proposed as a means to achieve this end.

Proponents of increased use of subordinated debt by banking firms argue that it can impose both direct and indirect market discipline on these firms. Direct discipline is exerted through investors' monitoring and increasing a bank's expected cost of issuing subordinated debt in response to an increase in the bank's perceived risk. Indirect market discipline is exerted when other agents, for example, banking supervisors, use the information from subordinated debt markets to increase the bank's cost of operations. The anticipation of higher funding and operation costs in response to higher risk taking is expected to provide banks with greater incentives to refrain from taking excessive risk. This, in turn, is expected to lower banks' vulnerability to insolvency and consequently to reduce the likelihood of systemic risk.

Most empirical studies in the field, such as Flannery and Sorescu (1996), DeYoung et al. (1998, 2001), Berger et al. (2000), Jagtiani et al. (2002), Sironi (2003), have focused on investigating two issues. First, whether subordinated debt holders understand banking firms' true condition and incorporate these assessments promptly into the yields on their subordinated debt. And second, whether subordinated debt markets provide banking supervisors with relevant and helpful information for use in monitoring and disciplining bank risk taking. However, little is known about whether having subordinated debt in place mitigates bank risk taking. In addition, while theories, such as in Decamps et al. (2004), Rochet (2004), Distinguin (2008), suggest that the disciplinary 
effect of subordinated debt on bank risk taking depends crucially on national bank regulations and legal and institutional conditions, to my knowledge, no study has attempted to investigate this issue empirically.

My study uses a sample of publicly listed commercial banks and bank holding companies around the world with data available over the period 2002-2008. With alternative measures of bank risk taking and empirical methods that address concerns about endogeneity and sample selection, I find evidence supporting the view that subordinated debt has a mitigating effect on bank risk taking. In particular, I show that this effect is not driven by sample selection bias, is robust to a variety of robustness checks, and is in place during the recent financial crisis. Moreover, the results suggest that the risk mitigating effect appears to be a distinctive feature of subordinated debt as a type of uninsured bank liabilities, possibly owing to its most junior status and a longer maturity than other uninsured bank debt. The evidence thus lends support to proposals calling for increased use of subordinated debt in banking firms. Also, the results are consistent with the prediction that there is some threshold level of national bank regulations and economic development above which subordinated debt exerts an effect on bank risk taking. In addition to regression analysis, I also conduct an event study where I use the nearest neighbor matching method to estimate the average effect on risk taking for banking firms that first have raw subordinated debt changed from zero to positive during the period 2003-2007. The results from this event study corroborate the study's key findings.

Examining risk taking by banks, my study is also closely related to the work of Laeven and Levine (2009) who study the effect of shareholders on bank risk taking. They provide evidence consistent with the view that large owners with substantial cash flow rights have greater incentives and power to increase bank risk taking than small shareholders, ${ }^{1}$ and that the relation between bank risk and national bank regulations depends on each bank's ownership structure. I, on the other hand, show that subordinated debt holders can help mitigate bank risk taking, and that this effect depends on national bank regulations as well as legal and institutional conditions.

\footnotetext{
${ }^{1}$ The result is consistent with standard agency theory of the increased risk-shifting incentives of shareholders in highly levered firms (Jensen and Meckling, 1976). Further, deposit insurance intensifies the ability and incentives of banks' shareholders to increase risk (Keeley, 1990).
} 
The rest of my dissertation is organized as follows. Chapter II discusses characteristics of subordinated debt and its relation with bank risk taking, and reviews the empirical and theoretical studies on this relation. Chapter III presents testable hypotheses. Chapter IV describes the methodology and data. Chapter V reports and analyzes empirical results on the risk mitigating effect of subordinated debt and various robustness checks. Chapter VI discusses policy implications, and Chapter VII concludes. 


\section{CHAPTER II}

\section{CHARACTERISITICS OF SUBORDINATED DEBT AND ITS RELATION WITH}

\section{BANKING FIRM RISK TAKING}

Since the 1980s, there have been several regulatory reform proposals to introduce a mandatory subordinated notes and debentures component as part of the bank capital requirement in the US. ${ }^{2}$ This is argued to be a means to increase market discipline on banking firms. Such proposals, however, as Evanoff and Wall (2007) point out, have not yet been implemented by US bank regulators as there are still concerns about using the signal extracted from debt yields to monitor or predict the viability of banking firms due to the lack of market depth, trading frequency, heterogeneous debt characteristics, and infrequency of issuance. Calomiris (1999) mentions that a market discipline approach failed to win sufficient political support, perhaps because the US Congress and many bank regulators were more comfortable with regulatory discretion than with marketcontrolled outcomes. However, it should be noted that proposals for a mandatory subordinated debt policy generally view supervisory review and market discipline as complementary rather than substitutes.

Efforts to enhance the role of market discipline are not specific to the US. In fact, market discipline is one of the three pillars of the Basel II Capital Accord (together with minimum capital requirements and supervisory review), and allowing/requiring subordinated debt as a part of regulatory capital is viewed as an indicator of enhanced private oversight. ${ }^{3}$ The perceived need for more effective market discipline has intensified for at least two reasons. First, the increasing size and complexity of banking organizations, such as through consolidation of banks and nonbank activities and the use of financial innovations, have significantly complicated bank supervision and regulation.

\footnotetext{
${ }^{2}$ For a summary of different generations of proposals on subordinated debt holding, see Kwast et al. (1999), Evanoff and Wall (2000), Lang and Robertson (2002).

${ }^{3}$ Allowing or requiring subordinated debt as a part of regulatory capital is a component of the Private Monitoring Index constructed by Barth et al. (2004) using the World Bank's survey data on national bank regulations. The index is widely used in studies examining the impact of national bank regulations on bank performance, efficiency and valuation (e.g. Barth, Caprio, and Levine, 2004, Beck, Demirguc-Kunt, and Levine, 2006, Barth, Lin, Lin, and Song, 2009).
} 
While the evidence on the opaqueness of banks is mixed, ${ }^{4}$ the dominating view, at least among financial regulators, is that bank assets and activities are more opaque than those of a generic firm. The second reason, which is closely related to the first, is the desire of financial regulators to lower the potential vulnerability of the banking and financial system to systemic risk that could have severely adverse effects on the real economy. ${ }^{5}$

To better understand why subordinated debt has been widely proposed by observers both within and outside the bank regulatory agencies as a means to enhance market discipline on banking firms, I first review the regulatory treatment of banking firms' subordinated debt and the characteristics that make it a potentially effective market discipline instrument, and then proceed with a summary of empirical and theoretical studies on the relation between subordinated debt and bank risk taking.

\subsection{Regulatory treatment of banking firms' subordinated debt}

The 1988 Basel Capital Accord, as amended subsequently, has been widely adopted as the framework for capital adequacy regulation at the national level. Bank capital, as defined by the Basel Capital Accord, is intended to absorb losses without the interests of the senior debt holders, especially insured depositors, being affected. Under the Basel standards, eligible capital includes shareholders' equity plus retained earnings and minority interests, general provisions and loss reserves, hybrid capital instruments, and subordinated debt. Among these instruments, shareholders' equity and disclosed reserves constitute Tier 1 (core) capital; Tier 2 capital consists of revaluation reserves and possibly undisclosed reserves, general provisions and loan loss reserves, hybrid capital instruments, and subordinated debt. In particular, subordinated debt, as its name suggests, is subordinated to senior debt (insured deposits, uninsured deposits, and other nonsubordinated debt) in default and includes conventional unsecured subordinated debt

\footnotetext{
${ }^{4}$ Morgan (2002) shows that major bond-rating agencies split substantially more over bank issues and insurance company issues than over other issues with similar features. On the contrary, using market microstructure properties and analysts' earnings forecast, Flannery et al. (2004) find no evidence that banks are more opaque. The authors add one caveat that banking firms are highly regulated and government regulations and supervision may cause banking firms' transparency, i.e. reduce their intrinsic opaqueness.

${ }^{5}$ Dell' Ariccia et al. (2008) show that banking crises have independent negative effects on growth, as banks must cut back their lending. The supply-side effects coupled with demand-side effects in the form of reduced consumer confidence have adverse effects on the real economy. The adverse effects could be severe regardless of whether the economy is market-based or bank-based (Reinhart and Rogoff, 2008, Tong and Wei, 2008).
} 
capital instruments with a minimum original fixed term to maturity of over five years. ${ }^{6}$ For regulatory purposes, an amortization factor of $20 \%$ per year is applied over the last five years to maturity of the debt. ${ }^{7}$ Subordinated debt cannot exceed $50 \%$ of Tier 1 capital for inclusion in the capital base. ${ }^{8}$

Apart from helping banking firms satisfy regulatory requirements, given the limits of deposit insurance per depositor in most deposit insurance schemes, subordinated debt represents a viable alternative source of finance. And in this respect, the tax treatment of debt versus equity makes it preferred to equity. ${ }^{9}$

\subsection{Subordinated debt as a market discipline instrument}

While subordinated debt is not the only bank liability potentially capable of providing market discipline, it is argued that subordinated debt issues have characteristics that make them particularly attractive for providing increased market discipline. ${ }^{10}$

First, for the price of a bank debt instrument to be risk-sensitive, investors must perceive that the government will not come to their rescue when the bank fails. Among bank liabilities, subordinated debt is uninsured. Further, it is the least senior of all debt obligations and thus the first, after equity, to lose value in the event of bank failure. Its yield, therefore, should be particularly sensitive to the risk of a banking firm. Also, the subordinated status of subordinated debt relative to other liabilities would provide its holders with a greater incentive to demand disclosure of the banking firm's risk. In turn, banking firms would have greater incentives to disclose relevant information on their risks so as to reduce the cost of subordinated debt. That cost would be lower, in part,

\footnotetext{
${ }^{6}$ The average maturity of subordinated debt issued in Basel Committee member countries over the period 1990-2001 is 11.4 years (Basel Committee on Banking Supervision, 2003).

${ }^{7}$ There are some national differences with respect to the amortization of subordinated debt. For example, in Germany, subordinated debt counts as $40 \%$ over last 2 years; in the UK, $20 \%$ is amortized annually over last 4 years (Basel Committee on Banking Supervision, 2003).

${ }^{8}$ As Tier 1 capital must reach at least $4 \%$ of risk weighted assets under the Basel standards, mandatory subordinated debt proposals typically set the minimum required subordinated debt at $2-3 \%$ of risk weighted assets.

${ }^{9}$ For funding purposes, other uninsured debt exhibits the same tax benefit. However, different types of banking firms' uninsured debt may co-exist owing to the heterogeneity of investors with preferences for different kinds of debt instruments and the depth of particular debt markets.

${ }^{10}$ For a detailed discussion of subordinated debt characteristics, see Kwast et al. (1999).
} 
because disclosure by banks would save research and analysis expenses for subordinated debt holders. Banks that take lower risks would benefit from effectively informing potential subordinated debt holders about their favorable situations. Banks with lessfavorable risk situations nevertheless would have to disclose information; otherwise, potential subordinated debt holders would have reason to draw adverse inferences.

Furthermore, banks would have less incentive to withhold similar information at subsequent reporting intervals, since any interruption would likely be interpreted as an attempt to conceal a deteriorating situation (US Shadow Financial Regulatory Committee, 2000).

Secondly, subordinated debt investors have incentive to monitor risk since they are exposed to losses, but they do not benefit from any upside gains that accrue to excessive risk-taking. Equity holders, while exposed to losses, can also reap gains from risk and thus have a much stronger preference for risk than subordinated debt investors have. Standard option pricing theory, such as in Gorton and Santomero (1990), Levonian (2001), suggests that, all else being equal, the value of equity increases with the risk of a banking firm's assets - the value of shareholders' implicit call option on the bank's assets is increasing in the volatility of the bank's assets. In contrast, for solvent banks, as shown by Black and Cox (1975), Gorton and Santomero (1990), Levonian (2001), subordinated debt loses value if asset risk rises, all else equal. Thus, the incentive of subordinated debt investors to monitor and limit bank risk-taking is similar to that of bank supervisors and in contrast to that of equity holders. ${ }^{11}$ Further, holders of subordinated debt are more likely to be sophisticated investors, ${ }^{12}$ hence, are potentially capable of accurately assessing changes in a bank's condition and taking actions accordingly.

\footnotetext{
${ }^{11}$ It is argued that subordinated debt is expected to provide market discipline only on banks that are clearly going concerns (Kwast el al., 1999). Intuitively, if a bank approaches insolvency, the only way subordinated debt holders could possibly be paid is for the bank to save itself by winning a large and risky bet; hence, in this case, the risk preferences of subordinated debt holders become more like those of shareholders. Theoretically, Black and Cox (1975), Gorton and Santomero (1990) show that, for banks that approach insolvency, the value of subordinated debt is an increasing function of asset risk, since subordinated debt is then effectively the residual claimant. This has implication for sample design and will be addressed later. Nevertheless, Ashcraft (2006) documents that an increase in the amount of subordinated debt in regulatory capital has an important positive effect in helping a bank recover from financial distress, possibly through restrictive covenants that prevent moral hazard during financial distress.

${ }^{12}$ According to Kwast et al. (1999) and Hart and Zingales (2010a), holders of bank subordinated debt are mostly institutional investors. On the other hand, no information about subordinated debt investors is
} 
Finally, subordinated debt has relatively long maturity that magnifies the risk sensitivity of subordinated debt investors; the longer maturity makes this instrument more responsive than short-term debt to bank actions that increase risk over the longer term. Also the fact that subordinated debt investors are not able to "run", i.e. withdraw their funds at short notice, provides the extra benefit of mitigating a systemic risk situation.

Given these characteristics, proponents of increased use of subordinated debt as a market discipline instrument argue that subordinated debt can impose both direct and indirect market discipline on banks. Direct discipline would result from an expected increase in the cost of issuing subordinated debt in response to an increase in the bank's perceived risk; to avoid this increased cost the bank would more prudently manage risk. The direct disciplinary effect of subordinated debt is better appreciated when viewed in the context of the existing deposit insurance system. The pricing of the current deposit insurance is insufficiently sensitive to the riskiness of various banks, and therefore, may encourage some banks to take additional risk. With subordinated debt being issued in place of insured deposits, the bank pays a price that is commensurate with its risk; hence, the "gain" from taking advantage of distortionary deposit insurance pricing is eliminated, at least for the portion of insured deposits that is replaced by subordinated debt. In brief, it is the sensitivity of subordinated debt pricing to banks' riskiness that is essential for direct discipline. In the context of subordinated debt rollovers, this price effect eliminates banks' ability to earn "risk-unadjusted abnormal returns". In other words, subordinated debt exercises direct discipline by raising the bank's cost of funds, thereby offsetting some or all of the gains that may flow to equity holders from increased risk exposure. ${ }^{13}$

Indirect market discipline would result when other agents use the information from subordinated debt markets to increase the bank's cost of operations. For example, bank supervisors could use debt yields as triggers for regulatory actions, such as conducting more frequent and intrusive on-site examinations, limiting a bank's activities, or raising capital requirements. The increased regulatory interference is likely to impose

available for Basel Committee member countries over the period 1990-2001 (Basel Committee on Banking Supervision, 2003). The Bankscope database used in this study also does not provide information about subordinated debt holders.

${ }^{13}$ Blum (2002), Distinguin (2008) show that, when subordinated debt replaces some of insured deposits, the sensitivity of subordinated debt pricing to bank riskiness leads a bank maximizing its expected surplus to choose a level of risk which is closer to the first best. 
significant costs on bank managers' time and severely damage the bank's reputational capital; activity restrictions reduce the ability of banks to diversify income flows; and increased regulatory capital requirements are likely to result in increased funding costs since public policies, through taxes and government guarantees, ranging from deposit insurance to bailouts of uninsured creditors of too-big-to-fail banking firms, in effect penalize equity financing. In addition, private parties could increase the banking firm's cost of funds, limit its supply of credit, or reduce its ability to engage in certain types of contracts, such as counterparty positions on derivative contracts, long-term commitments, or syndication agreements. Evanoff and Wall (2000) argue that the anticipation of these types of penalties, from either bank supervisors or private parties, provides banking firms with additional incentives to refrain from excessive risk taking.

While private placements of subordinated debt to independent third parties could increase direct market discipline, for subordinated debt to increase both direct and indirect market discipline, it is virtually essential that the debt instrument be traded in a competitive market to independent third parties, so that bank supervisors and private parties could monitor its secondary market prices. ${ }^{14}$

\subsection{Empirical and theoretical studies on the relation between subordinated debt and bank risk taking}

Embedded in statements about the market discipline effect of subordinated debt are two distinct aspects of market discipline: market monitoring and market influence, which are first distinguished in Bliss and Flannery (2000) and Flannery (2001). Market monitoring refers to the hypothesis that investors understand a financial firm's true condition and incorporate these assessments promptly into the firm's security prices. Market monitoring generates market signals that may convey useful information to supervisors. On the other hand, market influence is the process by which outside claimants influence a firm's actions, either directly by investors or indirectly by supervisors.

\footnotetext{
${ }^{14}$ In Basel Committee member countries over the period 1990-2001, in terms of the number of subordinated debt issues, 53\% are privately placed. However, as public placements tend to be significantly larger than private placements, in terms of the amounts issued, public placements account for $69 \%$. The US has the largest market in public subordinated debt issuance in terms of value over 1990-2001 (Basel Committee on Banking Supervision, 2003). The Bankscope database used in this study however does not allow distinguishing these two market types (see also footnote 43).
} 
Most studies investigating the market discipline impact of subordinated debt have focused on testing the market monitoring effect, specifically, on the relation between bank risk characteristics and yields on subordinated debt. While prior studies done before 1992, such as Avery et al. (1988), Gorton and Santomero (1990), do not find a significant relationship between bank risk characteristics and yield spreads on subordinated debt, ${ }^{15}$ more recent studies find evidence that subordinated debt yield spreads do reflect an issuing bank's financial condition. For example, Flannery and Sorescu (1996) find that firm-specific accounting risk measures are correlated with option-adjusted spread of subordinated debt over a Treasury bond with the same maturity in 1983-1991 and this correlation is mainly accounted for by the 1989-1991 period when conjectural government guarantees of subordinated debt weaken. DeYoung et al. (1998) and Jagtiani et al. (2002) find similar results for the 1989-1995 and 1992-1997 periods, respectively, when bank regulators have made it increasingly clear that subordinated debt holders are not protected should the bank fail. Similar evidence of subordinated debt's market monitoring effect is documented for subordinated debt issues in the European banking industry by Sironi (2003); in particular, the evidence is prominent after the formation of the European Monetary Union in late 1990s. More recently, Evanoff et al. (2007) show results indicating a superior, more informative risk-spread relationship surrounding the period of new debt issuance relative to other periods which they attribute to enhanced market transparency and liquidity surrounding new debt issues. In addition, Goyal (2005) provides evidence that subordinated debt holders can use restrictive covenants as an alternative channel to discipline bank risk taking. ${ }^{16}$ However, Krishnan et al. (2005) call into question the risk monitoring effect of subordinated debt. They argue that a relation between the levels of yield spreads and the levels of bank risk variables is a necessary but

\footnotetext{
${ }^{15}$ Possible reasons for lack of evidence in the early periods are: measurement errors in the yield spread measures, wrong specification of the relation between bank risk characteristics and yields on subordinated debt, and subordinated debt holders' perception of implicit government guarantees in the early periods.

${ }^{16}$ The author uses a sample of subordinated debt contracts issued by US bank holding companies during the 1974-1995. These contracts specify restrictions on investment, financing, and payout policies. He notes that since the Basel Capital Accord in 1988, for the purpose of sharpening investors' incentives to monitor their banks and ensuring the subordinate character of the debt, bank regulators have been standardizing debt contracts and restricting the ability of banks to include covenants in debt that qualifies as Tier 2 capital. In light of the study's findings that restrictive covenants in bank debt are important disciplining mechanisms, the author suggests that regulatory restrictions on including covenants in bank debt should be re-examined.
} 
not sufficient condition for yield spreads to serve as an information signal on changing bank risk; for subordinated debt to enhance risk monitoring, changes in bank risk should be reflected in spread changes. They do not find strong and consistent evidence of this relation.

Another strand of literature looks for evidence on the potential for indirect disciplinary effect of subordinated debt by comparing information available to regulators with that available to the private markets. Though bank supervisors have access to extensive inside information through the on-site examination process, studies' results, such as in Berger et al. (2000), DeYoung et al. (2001), Evanoff and Wall (2002), Krishnan et al. (2006), suggest that both financial markets participants and bank supervisors produce value-relevant information about the future soundness of banks, that private markets participants' assessments and supervisory assessments complement one another, and that market information could be utilized to improve the predictive accuracy of traditional monitoring models used by regulators to predict the future condition of banks. One implication of this line of research is that the primary value of subordinated debt may lie not in its ability to control bank risk taking directly, but rather in its ability to generate helpful market signals about bank condition to which supervisors could respond with timely and effective regulatory discipline.

On the other hand, few studies have directly investigated the market influence role of subordinated debt, i.e. whether or not the expected increase in the costs of funding and operations in response to an increase in the bank's perceived risk actually causes banks with subordinated debt to be less likely to adopt excessively risky strategies in the first place and/or to manage their risk more prudently. To my knowledge, there are two studies with mixed evidence. Ashcraft (2006) shows that, for a sample of US banks and bank holding companies, an increase in the ratio of subordinated debt to regulatory capital has a positive effect on the future outcomes of distressed banks. While this is the first article to provide evidence on the preventative influence role of subordinated debt, it does not adequately address a number of econometric issues, such as correcting the variance-covariance matrix of parameter estimates in the second stage of a nontraditional two-stage estimation and testing the validity of the suggested instrument (the state corporate income tax rate). Krishnan et al. (2005) focus mainly on testing the market 
monitoring effect of subordinated debt rather than on testing the preventative influence effect. For the latter test, using a sample of 28 US banks and bank holding companies, they examine changes in bank risk characteristics around the time a banking firm first issues subordinated debt (both raw risk changes and adjusted risk changes measured relative to size, leverage, and profitability matched non-subordinated-debt-issuing banking firms). They find no evidence of a significant change in bank-specific risk characteristics. The matching analysis, however, does not adequately control for factors that are expected to affect both the outcome and the propensity of banking firms to issue subordinated debt. Also, the small sample size does not allow meaningful generalization of the result.

While numerous proposals to introduce a mandatory subordinated debt policy have been drafted and critically discussed over the course of almost three decades, the theoretical research on the role of subordinated debt in enhancing market discipline provides different implications, depending on the time structure of the models and the assumptions used. Levonian (2001) models subordinated debt issued by a bank as a contingent claim on the bank's assets. Within the context of the model, subordinated debt has few advantages over equity, either as a form of capital or as a source of market discipline. The model also illustrates that subordinated debt prices contain no information about the condition of issuers beyond what could be derived from their equity prices. However, the author also notes that if the noise in subordinated debt pricing is not perfectly correlated with the noise in equity pricing, the use of the two should lead to better estimates of asset value and asset volatility. ${ }^{17}$ Blum (2002), using a static model, shows that subordinated debt reduces risk only if banks can credibly commit to a given level of risk. However, if banks cannot commit, subordinated debt leads to an increase in risk. Due to limited liability, banks always have an incentive to increase their risk after the interest rate is contracted in order to reduce the expected costs of debt. Rational debt holders anticipate this behavior and accordingly require a higher risk premium ex ante.

\footnotetext{
${ }^{17}$ It should also be noted that empirical studies on the potential of subordinated debt to exert indirect disciplinary effect show that supervisory assessments and bond market indicators are strongly interrelated, while supervisory assessments and equity market indicators are not. This difference could be attributed to divergent incentives. Hence, subordinated debt markets are potentially capable of providing relevant, useful information to supervisors.
} 
The higher interest rates in turn further aggravate the excessive risk-taking incentives of banks. However, it should be noted that the implication of the model could be attributed to its time structure; in a dynamic setting, low-risk equilibria become feasible. Moreover, the model does not explicitly consider the role of banking regulators and the potential indirect market discipline effect of subordinated debt.

In fact, when examining the interaction and the optimal mix of the three pillars of the Basel Capital Accord (capital adequacy requirement, supervisory review and market discipline) in a continuous time setting, Decamps et al. (2004) and Rochet (2004) show that subordinated debt can constrain risk taking. In particular, direct market discipline is effective when the credibility of supervisors to close insufficiently-capitalized banks is established and subordinated debt holders are exposed to full losses. ${ }^{18}$ With regard to indirect market discipline, the intensity of regulation can be modulated according to market information, and symmetrically, supervisors can be forced to intervene when market signals reveal the distress of a bank. Thus, market discipline and supervisory actions are complementary rather than substitutes. Niu (2008)'s dynamic discrete-time model also supports proposals calling for increased use of subordinated debt. The author proposes an answer to the question raised by Blum (2002): how can a bank credibly commit to choosing a given level of risk after debt issuance? He shows that, under the assumption that creditors can imperfectly observe which type of assets the bank has chosen before debt issuance, the bank can use its existing safe assets as a commitment and bonding device. The implication is that banks reduce their risk before they issue subordinated debt. Distinguin (2008) sets up a model where a bank chooses a level of monitoring that maximizes its expected value, and the bank's risk is subject to banking supervision. She shows that requiring banks to issue subordinated debt reduces bank risk and allows a better allocation of supervisory resources if subordinated debt holders have access to sufficient information about banks' condition, and they do not benefit from any kind of insurance, either explicit or implicit.

It should be noted that to keep the models tractable, these theoretical studies do not address the agency problem between managers and shareholders, but assume that

\footnotetext{
${ }^{18}$ Subordinated debt's direct market discipline is compatible with public liquidity assistance, if such assistance is deemed socially desirable, provided that subordinated debt holders lose their stake if the bank is rescued.
} 
bank managers act in the best interest of shareholders. In practice, bank managers' and shareholders' interests could be aligned though appropriately designed compensation schemes. On the other hand, as shown in Jensen and Meckling (1976), Demsetz and Lehn (1985), bank-specific human capital skills and private benefits of control may cause bank managers to opt for less risk taking than shareholders without those skills and benefits. ${ }^{19}$

${ }^{19}$ In the empirical analysis, when possible, I control for managerial compensation/ownership together with other corporate governance attributes (See subsections 4.1.3 and 5.1.8). 


\section{CHAPTER III}

\section{HYPOTHESES}

While subordinated debt has characteristics that make it potentially capable of mitigating bank risk taking, it is expected to be an effective market discipline instrument only when certain conditions are satisfied. The following four testable hypotheses are formed based on the implications of theoretical studies discussed earlier.

For subordinated debt to work as a market discipline instrument, a necessary condition is that subordinated debt holders have access to sufficient information to assess a bank's true condition (Decamps et al., 2004, Rochet, 2004, Distinguin, 2008). Therefore, the effect of subordinated debt on bank risk taking is expected to depend on national bank regulations that foster private oversight.

In addition, for subordinated debt to impose indirect discipline on bank risk taking, i.e. through providing regulators with information for use in their supervision, a necessary condition is that the supervisory authorities have the authority to take specific actions to prevent and correct problems in banks upon receiving the relevant information from subordinated debt markets. ${ }^{20}$ Therefore, the indirect disciplinary effect of subordinated debt on bank risk taking is expected to depend on national bank regulations that duly empower supervisory authorities.

The effectiveness of subordinated debt in imposing market discipline could be undermined if, for example, it is not held at arm's length or credit enhancement is used to support the debt (Calomiris, 1999, Evanoff and Wall 2000), i.e. the lender is provided with reassurance that the borrower will honor the obligation through additional collateral, insurance, or a third party guarantee, hence, credit enhancement reduces credit/default risk of the debt. Better economic and financial development is likely to go hand in hand with a strong legal system (La Porta et al., 1997, 1998), which could have built-in mechanisms and regulations to thwart insider arrangements. In addition, better economic and financial development is likely to be directly associated with more sophisticated investors, which in turn is a necessary condition for subordinated debt to effectively impose market discipline on banks. Therefore, the market discipline effect of

\footnotetext{
${ }^{20}$ This is consistent with Decamps et al. (2004) and Rochet (2004) model implications.
} 
subordinated debt on bank risk taking is expected to depend on or be associated with a country's level of economic development.

Theories suggest that subordinated debt can work as a market discipline instrument in the absence of regulatory forbearance and government implicit guarantees (Decamps et al., 2004, Rochet, 2004, Distinguin, 2008). It is well documented in the banking literature that banking authorities are often subject to political pressure for bailing out creditors of distressed banks that are perceived to be too big to fail. Therefore, the market discipline effect of subordinated debt is expected to be nonexistent or, at most, weaker in too-big-to-fail banks and banks in which the government has a considerable stake, hence, an incentive to bail them out. 


\section{CHAPTER IV}

\section{DATA AND METHODOLOGY}

\subsection{Variable descriptions}

In this subsection I discuss the main variables of interest. Definitions of all variables used in the empirical analysis can be found in Table $\mathrm{I}^{21}$

\subsubsection{Measuring subordinated debt}

A reasonable test of the market influence effect of subordinated debt would be to compare how banks that start with the same levels of risk-weighted assets ${ }^{22}$ (thus have similar initial assets risk) but have different amounts of subordinated debt on their balance sheets to support the risk-weighted assets differ in terms of future risk taking. Thus, a relevant measure of subordinated debt should be the ratio of subordinated debt to risk-weighted assets. The level of a bank's risk-weighted assets is not directly available from the bank's balance sheet but could be computed if either both Total Capital and Total Capital Ratio or both Tier 1 Capital and Tier 1 Capital Ratio are available since the denominator used in computing these capital ratios is the bank's total risk-weighted assets (Total Capital Ratio equals Total Capital divided by total risk-weighted assets, and Tier 1 Capital Ratio equals Tier 1 Capital divided by total risk-weighted assets). Unfortunately, these capital ratios cannot be calculated simply by looking at the balance sheet of a bank but have to be calculated internally by the bank. Banks may publish these

\footnotetext{
${ }^{21}$ All main tables are included in Appendix A.

${ }^{22}$ Market risk, operational risk, and credit risk are accounted for in calculating the total risk-weighted assets (Basel Committee on Banking Supervision, 2001). Risk-weighted assets are the denominator used in determining the minimum regulatory capital requirements (Tier 1 Capital Ratio and Total Capital Ratio). $94.1 \%, 98.7 \%$, and $98.6 \%$ of countries that participated in the World Bank's Surveys I, II, and III, respectively, on national bank regulations answered "Yes" to the question whether the minimum capitalasset ratio is risk-weighted in line with the Basel guidelines. Risk-weighted assets are also the most frequently used denominator in determining the minimum subordinated debt ratio in proposals for a mandatory subordinated debt policy. While one can always argue that the risk weighting scheme used in constructing the risk-weighted assets is debatable, and that the risk-weighted assets are not perfectly comparable across banks, in the absence of a better measure, a bank's amount of risk-weighted assets is expected to be more informative about the initial riskiness of the bank's assets than other measures such as the amount of total assets or the amount of total liabilities.
} 
numbers in their annual reports or may not. ${ }^{23}$ Therefore, using the ratio of subordinated debt to risk-weighted assets as the main measure of subordinated debt results in a smaller sample size.

An alternative measure of subordinated debt is the ratio of subordinated debt to total liabilities. The advantage of using this measure is that a bank's total liabilities are readily available from its balance sheet, hence, the resulting sample is larger. The disadvantage is that the implication of a test using this measure of subordinated debt is less clear since the level of total liabilities per se is less informative about the riskiness of the bank's assets.

I use the ratio of subordinated debt to risk-weighted assets as the main measure of subordinated debt in the analysis and the ratio of subordinated debt to total liabilities as a robustness check.

\subsubsection{Measuring bank risk taking}

An increasingly used measure of bank risk taking is the z-score of each bank - the distance from insolvency. ${ }^{24}$ Specifically,

$$
z=\frac{R O A+C A R}{\sigma(R O A)}
$$

with $A$ denoting assets, $E$ equity, and $\pi$ profits, $R O A \equiv \frac{\pi}{A}$ is the return on average total assets, $C A R \equiv \frac{E}{A}$ is the equity capital-assets ratio, and $\sigma(R O A)$ is the standard deviation of the return on average total assets. ${ }^{25}$ Let $F(R O A)$ denote a bank's return distribution. Insolvency risk is defined as the probability that losses exceed equity:

$$
P(\pi \leq-E)=P(R O A \leq-C A R)=\int_{-\infty}^{-C A R} F(R O A) d R O A
$$

\footnotetext{
${ }^{23}$ Potential issues with banks' choice of reporting these numbers are discussed in a later subsection.

${ }^{24}$ See, for example, Laeven and Levine (2009), Maechler et al. (2007), Lin et al.(2005), De Nicolo (2000), Altman and Saunders (1998). Since the z-score is highly skewed, I use the natural logarithm of the z-score in the analysis.

${ }^{25}$ The standard deviation of the return on average total assets is computed over a moving window of 4 years. With respect to the return on average total assets, using the four-year moving average return on average total assets or one-year return on average total assets in computing the z-score produces qualitatively similar results. Since the aim is to construct a measure of future risk taking, I use the one-year return on average total assets to compute the z-score used in the main analysis.
} 
Roy (1952) and De Nicolo (2000) show that:

$$
P(R O A \leq-C A R) \leq \frac{1}{Z^{2}}
$$

At the upper bound of insolvency risk:

$$
P(R O A \leq-C A R) \equiv p=\frac{1}{z^{2}}
$$

Then:

$$
\begin{aligned}
& \ln z=-\frac{1}{2} \ln p \\
& \ln z \approx-\frac{1}{2}(p-1) \\
& \ln z \approx \frac{1}{2}(1-p)
\end{aligned}
$$

Approximation (3) defines a strictly linear relationship between the natural logarithm of z-score, the measure of risk taking used in my study, and the probability of insolvency. This approximation works well for values of $p$ that are closer to 1 than to 0 a condition that does not hold in the data. Nevertheless, equation (2) implies a strictly monotonic relationship between the natural logarithm of z-score and the probability of insolvency. A higher $\ln z$ is associated with a lower $p$ and vice versa. More generally, (1) and (2) show that minimizing $P(R O A \leq-C A R)$ is equivalent to maximizing $\ln z$. Therefore, it is plausible to use $l n z$ as a measure of insolvency risk. ${ }^{26}$

Under the assumption of normality of banks' returns:

$$
P(R O A \leq-C A R)=\int_{-\infty}^{-z} N(0,1) d R O A
$$

The relationship between $P(R O A \leq-C A R)$ and $z$ is strictly monotonic. In this case, $z$ measures the number of standard deviations a return realization has to fall in order to deplete equity. ${ }^{27}$ Thus, a higher z-score indicates that the bank is more stable.

\footnotetext{
${ }^{26}$ As a matter of fact, (1) shows that the nonlinear relationship between $z$ and $p$ poses a problem only if both negative and positive values of $z$ are included in the analysis, as $p$ is positively correlated with $z$ for negative values of $z$, but negatively correlated with $z$ for positive values of $z$. Recall that subordinated debt is expected to provide market discipline only on banks that are clearly going concerns (Kwast el al., 1999), hence, banks with negative values of z-score (i.e. are clearly in distress), are by design not supposed to be included in the analysis.

${ }^{27}$ I assess if the assumption of normality of banks' return holds in the data in Chapter V.
} 
Alternative measures of bank risk used in the analysis are earnings volatility and standard deviation of return on average total assets. Earnings volatility equals the standard deviation of the ratio of total earnings before taxes and loan loss provisions to average total assets, computed over a moving window of 4 years. The same moving window is used in computing the standard deviation of return on average total assets.

\subsubsection{Bank-level control variables}

Laeven and Levine (2009) show that banks that have large owners with substantial cash flow rights tend to take more risk. To proxy for ownership, I use the Bureau Van Dijk Independence Indicator variable, which takes value one if there is no shareholder having more than $25 \%$ of direct or total ownership. Data permitting, I use the last ownership data available up to December $2006 .{ }^{28}$ For example, if a bank's last year of data in the Bankscope database is 2004, then the 2004 ownership data is used. For banks that remain in the database after December 2006, I use the ownership data recorded in December 2006 or December 2005, if available. ${ }^{29}$ A bank is dropped from the final sample if its ownership data is not available before or in December 2006. There are potential problems with this approach; the most obvious is that I am using this data to proxy for bank ownership for the period 2002-2007. However, there is also some justification for doing this. Laeven and Levine (2009) use thresholds of $10 \%$ and $20 \%$ to define a large owner ${ }^{30}$ and report that bank ownership changes extremely little over time. Thus, a higher cut-off used to define the Bureau Van Dijk Independence Indicator makes it less likely that a bank switches from one category of ownership to the other during normal time. To check if the result is sensitive to the ownership data, I estimate a specification where explanatory variables are measured in (up to) 2006, and bank risk taking is measured over 2007-2008, i.e. after bank ownership is observed.

\footnotetext{
${ }^{28}$ Bankscope reports the most recent ownership data.

${ }^{29}$ Historical ownership data for December 2006 and December 2005 was provided by Bureau Van Dijk.

${ }^{30}$ Laeven and Levine (2009) also use the 2001 ownership database to study bank risk taking averaged over 1996-2001. For an example with studies using panel data, Weisbach (1988) uses 1980 data to measure board control for 1974 to 1983; the assumption is that there is little change in board shareholdings.
} 
Goyal (2005) argues that risk taking incentives of banks depend on the value of their charter, which reflects future economic rents that banks obtain from privileged access to markets protected from competition. I follow Goyal (2005) in using the ratio of demand deposits to total deposits as a proxy for bank charter value. ${ }^{31}$ Other commonly used bank-level control variables are size, computed as the natural logarithm of total assets in thousands of US dollars, loan growth, liquidity ratio and loan loss provisions ratio.

In extended versions of the main regression specification, I also control for other uninsured debt and bank-level corporate governance. Specifically, short-term uninsured debt is measured as deposits and short-term funding less total deposits. Other long-term uninsured debt is measured as total other funding less subordinated debt. Other uninsured debt is then the sum of the short-term and the other long-term uninsured debt. All of these measures are normalized alternatively by the bank's total risk-weighted assets or total liabilities.

Bank-level corporate governance data provided by the Institutional Shareholder Services (ISS) is available for US firms only. Since the methodology that the ISS uses to construct the Corporate Governance Quotient (CGQ) for US firms has changed over time (in terms of the number of included governance attributes as well as the governance standards associated with governance attributes), I construct governance indexes using those attributes that are consistent over time ( 52 attributes in four broad categories: board of directors, audit, anti-takeover, and managerial compensation/ownership). The first constructed index is expressed as a percentage, where satisfying all 52 attributes earns a firm an index of $100 \%$; if an attribute is missing then the index represents the percentage of non-missing attributes that are satisfied. The second constructed index is additive. In addition, I also use the ISS' Industry CGQ as a robustness check.

\subsubsection{Country-level control variables}

To control for country heterogeneity I use country dummies and the natural logarithm of GDP per capita, which is highly correlated with a country's level of

\footnotetext{
${ }^{31}$ Arguments for using demand deposits ratio as a proxy for bank charter value can be found in Keeley (1990), Neumark and Sharpe (1992), Hutchison and Pennacchi (1996).
} 
financial development and rule of law index. ${ }^{32}$ There is always a chance that some timevariant country characteristic is unobserved or cannot be measured, and hence not controlled for. However, if there is little variation over time in these country characteristics, as it is generally assumed to be the case for measures of institutional conditions such as accounting standards and costs of smoothing earnings, their effects are likely to be largely captured by the country fixed effects.

With respect to national bank regulations, I use three regulation measures that are closely related to the three pillars of the Basel Capital Accord. These are the capital regulation index, the supervisory power index and the private monitoring index. These indexes are computed using the World Bank's survey data on national bank regulations ${ }^{33}$ and the methodology in Barth et al. (2004).

The capital regulation index is an index of regulatory oversight of bank capital, accounting for both initial and overall capital stringency. It includes information on whether certain funds may be used to initially capitalize a bank, whether these funds are officially verified, and whether there are explicit regulatory requirements regarding the amount of capital that a bank must have relative to various guidelines. The official supervisory index measures the extent to which official supervisory authorities have the authority to take specific disciplinary actions to prevent and correct problems. The private monitoring index captures the extent to which bank regulations force banks to disclose accurate information to the public and induce private sector monitoring of banks. To focus on the effect of regulations on information disclosure and deposit insurance, I

\footnotetext{
${ }^{32}$ Financial development is measured as the sum of stock market capitalization to GDP and total credit to the private sector as a share of GDP (Levine and Zervos, 1998, Levine, 2004). The Rule of Law Index is constructed by Kaufmann et al. (2008) and reflects the extent to which agents have confidence in and abide by the rules of society, and in particular the quality of contract enforcement, property rights, the police, and the courts, as well as the likelihood of crime and violence. The pairwise correlations of GDP per capita, financial development and rule of law index are in the 0.80 range.

${ }^{33}$ The first survey data was collected in late 1990s and early 2000s. The second survey describes the regulatory environment at the end of 2002. The third survey describes the situation in 2006 (Barth et al., 2008). For years in which no survey was conducted, I assume that banking regulations remain unchanged in the years following the most recent survey. Specifically, Survey I data is used for year 2002, Survey II data for years 2003, 2004, 2005, and Survey III data for years 2006 and 2007. Many other studies that have used this database across a number of years follow a similar approach (e.g. Demirguc-Kunt et al., 2004, Beck et al., 2006).
} 
also construct a sub-index of the private monitoring index, which is the disclosureinsurance index. ${ }^{34}$ Detailed description of these indexes is provided in Table I.

One limitation of these national bank regulation measures is that they contain little variation over time and thus are expected to be largely indistinguishable from country specific effects that may reflect other features than the banking regulatory environment. I discuss a way to address this issue in the next subsection.

\subsection{Methodology}

\subsubsection{Main regression specification}

To assess the impact of subordinated debt on bank risk taking during the period 2002-2008, I estimate the following model, which is built on the base specification in Laeven and Levine (2009), who study the effect of shareholders on bank risk taking:

$$
\begin{aligned}
& \text { Bank-level risk taking }=a+b_{1}(\text { Bank-level SND ratio })+b_{2}(\text { Bank-level Control } \\
& \text { Variables })+b_{3}(\text { Country-level Control Variables })+b_{4}(\text { Year dummies })+e
\end{aligned}
$$

Bank-level risk taking is measured by the z-score, the standard deviation of return and the earnings volatility. Bank-level SND ratio is the ratio of subordinated debt to total risk-weighted assets or total liabilities. Bank-level control variables are the Bureau Van Dijk independence indicator, the demand deposits ratio, bank size, loan growth, liquidity ratio and loan loss provisions ratio. Country-level control variables include the natural logarithm of GDP per capita, the capital regulation index, the supervisory power index, the private monitoring index (disclosure-insurance index), and country dummies. All explanatory variables, except for country dummies and year dummies, are lagged by one year. Standard errors are clustered by country. ${ }^{35}$

\footnotetext{
${ }^{34}$ The private monitoring index and disclosure-insurance index are informative about whether there is an explicit deposit insurance scheme and, if not, whether depositors were fully compensated the last time a bank failed. Subordinated debt is explicitly uninsured. The above-mentioned indexes do not reflect whether or not subordinated debt holders may benefit from implicit government guarantees. Moreover, this question is likely to be relevant at the bank level rather than at the country level. I investigate the market discipline effect of subordinated debt on the risk taking of too-big-to-fail banks in Chapter V.

${ }^{35}$ Two-way clustering by country and year is not feasible because the number of years is too small (For a discussion on this, see Cameron et al., 2006, Thompson, 2009, and Petersen, 2009). Therefore, I follow recommendation in Petersen (2009) to use year dummies and estimate standard errors clustered on country.
} 
There is no reason for the market discipline effect of subordinated debt to be linear in the national bank regulations or the country's level of economic development. It could well be the case that there is some threshold level of national bank regulations and economic development above which subordinated debt could exert the desirable effect. To investigate this possibility, I split the sample between High and Low on each of the relevant national bank regulations and the country's level of economic development to test each of the four hypotheses proposed earlier. This procedure is also one way to examine the impact of national bank regulations on the market discipline effect of subordinated debt that does not have to rely heavily on the limited time series variation of national bank regulation measures discussed earlier.

\subsubsection{Econometric issues}

A number of econometric issues in the regression analysis need to be addressed. One issue is the potential endogeneity of the regressors. In particular, for most countries participating in the World Bank surveys, subordinated debt is allowable, but not required, as a source of capital; hence banks choose to have subordinated debt and how much to have. If, for example, only banks with a reputation of being efficient, safe and sound banks choose to issue subordinated debt, then the subordinated debt variable is not exogenous. This, in turn, leads to inconsistent coefficient estimates and unclear inferences about the direction of causality. I address the issue of endogeneity of regressors in a number of ways. First, in specification A, explanatory variables are lagged by one year. Second, to deal with the endogeneity of the subordinated debt measure, I conduct all regression analyses using the instrumental variable approach to isolate plausibly exogenous variation in the subordinated debt measure.

Inspired by Caprio et al. (2007) and Laeven and Levine (2009), I use the average subordinated debt ratio of other banks in the same country, year and size group as one instrument for a bank's subordinated debt ratio. ${ }^{36}$ This measure is meant to capture

\footnotetext{
${ }^{36}$ Specifically, for each measure of subordinated debt, if the number of banks with non-missing value of subordinated debt ratio in a given country and year is greater than 5 , the banks are categorized into two size groups depending on whether bank size is below or at/above the median size. If the number of banks with non-missing value of subordinated debt ratio in a given country and year is less than or equal to 5, the average subordinated debt ratio of other banks in the same country and year is computed and used as an instrument for a bank's subordinated debt ratio. This is to reduce the possibility that only one bank ends up in a size category, which eventually amounts to losing that observation.
} 
country, industry, and peer-group factors explaining subordinated debt ratio. Note that it is necessary that this instrument be constructed using a bank-level characteristic (size, in this case) for it to have explanatory power. Otherwise, its effect would be largely absorbed by the country fixed effects. Size is chosen as the relevant bank-level characteristic because it is observed that, at least for countries with a relatively large number of banks in the sample, there appears to be a positive correlation between bank size and the presence of subordinated debt on the bank's balance sheet.

In addition, as discussed in Kwast et al. (1999), banking firms with larger equityto-assets ratios may be perceived to be less likely to fail for a given level of risk than those with smaller equity-to-assets ratios, hence, they may have a lower expected subordinated debt spread and be more willing to issue subordinated debt. On the other hand, banking firms with smaller equity-to-assets ratios may have a greater desire to issue subordinated debt because of the need to raise Tier 2 capital. Therefore, I use the bank's lagged equity-to-assets ratio as the second instrument for its subordinated debt ratio. Kwast et al. (1999) also discuss the tax benefit of subordinated debt. Presumably, the higher the bank's tax rate, the greater the benefit from being able to deduct the interest payments paid to subordinated debt holders. I use the bank's average tax rate, computed as tax expense divided by profit before tax, as the third instrument for its subordinated debt ratio. While the suggested instruments are expected to be correlated with a bank's subordinated debt ratio, they are unlikely to have a direct effect on the bank's future risk taking; therefore these instruments are expected to reduce endogeneity bias. Their validity will be tested empirically.

Another potential issue is related to banking firms' choice to report the Total Capital Ratio and Total Capital and/or Tier 1 Capital Ratio and Tier 1 Capital. If the banks that report these numbers tend to behave differently with respect to future risk taking then the analysis using the ratio of subordinated debt to risk-weighted assets, i.e. using the sample of banks that report the capital ratios, could suffer from sample selection bias. I address this issue in two ways. First, I estimate equation A using the ratio of subordinated debt to total liabilities instead. Second, I investigate whether the choice of reporting the capital ratios is systematically correlated with future risk taking by estimating the following system of equations (a treatment-effects version of the bivariate 
normal selection model) for all banks with non-missing values of z-score and explanatory variables for the period 2002-2008.

$$
\begin{aligned}
& \text { Report }=\mathrm{c}+\mathrm{d}_{1}(\text { Accounting standard })+\mathrm{d}_{2}(\text { Bank characteristics })+ \\
& \qquad+\mathrm{d}_{3}(\text { Country-level Control Variables })+\mathrm{d}_{4}(\text { Year dummies })+\mathrm{u} \\
& \text { Bank-level risk taking }=\mathrm{a}+\mathrm{b}_{1}(\text { Report })+\mathrm{b}_{2}(\text { Bank characteristics })+ \\
& +\mathrm{b}_{3}(\text { Country-level Control Variables })+\mathrm{b}_{4}(\text { Year dummies })+\mathrm{e}
\end{aligned}
$$

Report is a dummy variable that takes value 1 if a bank reports either the Total Capital Ratio and Total Capital or Tier 1 Capital Ratio and Tier 1 Capital, and zero otherwise. Accounting Standard is a dummy variable that takes value 1 if the bank reports according to IAS, IFRS, Regulatory standard, or local GAAP (for US banks only), and zero otherwise. The Accounting Standard is the excluded exogenous variable since it is likely that a bank's reporting practice is governed, at least partly, by accounting standards and common disclosure practice. Note that the ratio of subordinated debt to risk-weighted assets cannot be on the right hand side of the second equation because it is missing when Report takes value zero; however, the future outcome is observed for both banks that report and banks that do not report the capital ratios. The bank characteristic variables are bank ownership, loan growth, size, demand deposits ratio, liquidity ratio, loan loss provisions ratio, and leverage. ${ }^{37}$

The first equation estimates the propensity to report the capital ratios, and the second equation predicts the bank's future risk taking as a function of its choice of reporting these capital ratios. The inverse Mills ratio vector obtained from estimating the first equation is used as a regressor in estimating the second equation so that the coefficient on Report in the second equation is purged of any problem due to potentially endogenous selection of banks into the "treatment" - reporting the capital ratios. The two-step estimates are then used as starting values for full information maximum likelihood estimation. The estimates of $b_{1}$ and rho (the correlation of $u$ and $e$ ) can then be used to judge whether sample selection bias exists in the data. If reporting the capital

\footnotetext{
${ }^{37}$ Leverage can be included because sub-debt ratio is not in the equations. One of the instruments for subdebt ratio - the lagged equity-to-assets ratio is highly correlated with leverage; the pairwise correlation is 0.93 .
} 
ratios or not is not systematically correlated with future risk taking, then using a sample of banks that report should not pose a problem.

\subsubsection{Event study}

Niu (2008) suggests that banks can use their existing safe assets as a commitment and bonding device, hence banks may reduce their risk before issuing subordinated debt. To examine this possibility, I use the matching estimator to estimate the average treatment effect on bank risk taking one year before and one year after the treatment, where the treatment is defined as bank first having raw subordinated debt changed from zero to positive during the period 2003-2007. The test could have power if the first time a bank issues subordinated debt signifies a higher level of monitoring that it is exposed to; on the other hand, the test may have low power if some unknown threshold level of subordinated debt is required before it could have the desirable effect on bank risk taking.

Let $D_{i, t}$ be an indicator of whether bank $i$ has raw subordinated debt changed from zero to positive for the first time at time $t$. Let $y_{i, t+s}^{1}$ denote the risk measure of bank $i$ at time $t+s$. Also let $y_{i, t+s}^{0}$ denote the risk measure if the bank had not issued subordinated debt. The average effect of first issuing subordinated debt on bank risk taking for the treated banks is:

$$
E\left(y_{i, t+s}^{1}-y_{i, t+s}^{0} \mid D_{i, t}=1\right)=E\left(y_{i, t+s}^{1} \mid D_{i, t}=1\right)-E\left(y_{i, t+s}^{0} \mid D_{i, t}=1\right)
$$

where $E\left(y_{i, t+s}^{0} \mid D_{i, t}=1\right)$ is unobserved. For each treated bank $i$, the matching estimator imputes the missing potential outcome by using the average outcome for untreated (control) banks with similar observable characteristics. In the analysis that follows I adopt the method of nearest neighbor matching with replacement, proposed by Abadie and Imbens (2002) and Abadie et al. (2004). In particular, I use the bias-corrected matching estimator that adjusts the difference within the matches for the differences in the values of their observables. Let $N$ be the number of treated banks, and let $J_{M}(i)=$ $\left\{j_{1}(i), \ldots, j_{M}(i)\right\}$ denote the set of indices for the first $M$ matches for bank $i$. Let $\mu_{D}(X)=$ $E\left[y^{D} \mid X\right]$ where $X$ is a vector of observables, and let $\hat{\mu}_{D}\left(X_{i}\right)$ be a consistent estimator of $\mu_{D}\left(X_{i}\right)$. The bias-corrected matching estimator for the average treatment effect on bank risk taking for treated banks is: 


$$
\begin{gathered}
\hat{\tau}_{M}=\frac{1}{N} \sum_{i: D_{i}=1}\left\{y_{i}-\tilde{y}_{i}^{0}\right\} \\
\text { where } \tilde{y}_{i}^{0}=\frac{1}{M} \sum_{j \in J_{M}(i)}\left\{y_{j}+\hat{\mu}_{0}\left(X_{i}\right)-\hat{\mu}_{0}\left(X_{j}\right)\right\}
\end{gathered}
$$

Treated banks are banking firms that first have raw subordinated debt changed from zero to positive during the period 2003-2007. The control group for a particular year includes banking firms that have not had subordinated debt on their balance sheets up to that year. ${ }^{38}$ To estimate the average treatment effect on bank risk taking for treated banks one year after the treatment, i.e. in year $t+1$, treated and control banks are matched based on their observable characteristics in year t-1. Similarly, to estimate the average treatment effect on bank risk taking for treated banks one year before the treatment, i.e. in year $\mathrm{t}-1$, treated and control banks are matched based on their observable characteristics in year t2. The observable characteristics include factors expected to affect both outcome and treatment. The bank-level control variables discussed earlier, namely, bank size, demand deposits ratio, loan growth, loan loss provisions ratio, liquidity ratio, and independence dummy are expected to affect banks' future risk taking. On the other hand, the capital-toassets ratio and the average tax rate may affect a bank's desire to issue subordinated debt. In addition, I specify exact matching by country and year so that matched banks operate in common macro and bank regulation environment. ${ }^{39}$

\subsection{Sample}

The sample consists of all publicly listed commercial banks and bank holding companies (hereafter referred to as banking firms) in Bankscope, a commercial database on major international banks, from 2002 to 2008 that have the needed data items available. ${ }^{40}$ There are two reasons for choosing publicly listed banking firms. First,

\footnotetext{
${ }^{38}$ More precisely, the control banks for a particular year have not had subordinated debt on their balance sheets from 1996 up to that year. Bankscope imposes a time limit on coverage of individual banks' historical data.

${ }^{39}$ In implementation, I also explicitly specify GDP per capita, capital regulation index, supervisory power index, and disclosure-insurance index among the covariates used in the matching because these variables are to be used in the bias correction. See Abadie and Imbens (2002) and Abadie et al. (2004) for details.

${ }^{40}$ I use bank consolidated statements. However, to keep as many observations as possible, if a bank does not issue consolidated statement, I use its unconsolidated account (the financial statement of a firm that does not have controlling interests in any other firms is, by definition, unconsolidated). The advantage of using consolidated accounts is that internal transactions are canceled out. Proposals for a mandatory
} 
focusing on publicly listed banking firms enhances comparability across countries with respect to accounting standards. Second, I assume that it is easier for banking firms that have equity listed to issue publicly traded subordinated debt, which is necessary for indirect market discipline. This procedure will leave out the publicly traded subordinated debt issued by banking firms that do not have equity listed, and include the privately placed subordinated debt of banking firms that have equity listed. The inclusion of some privately placed subordinated debt in the analysis is likely to bias against finding strong evidence of market discipline since indirect market discipline is virtually not possible with this type of subordinated debt.

I begin the sample in 2002 to make use of the first World Bank survey on national bank regulations. I exclude banks from countries not included in the World Bank database. The sample where the subordinated debt measure is the ratio of subordinated debt to total liabilities (hereafter referred to as Sample I) is comprised of 1,115 banking firms from 77 countries with 4,442 firm-year observations. The sample where the subordinated debt measure is the ratio of subordinated debt to risk-weighted assets (hereafter referred to as Sample II) consists of 776 banking firms from 53 countries with 2,280 firm-year observations.

Sample II is noticeably smaller than Sample I for two reasons. First, as mentioned earlier, not all bank-year observations with non-missing value of raw subordinated debt have data on Total Capital and Total Capital Ratio and/or Tier 1 Capital and Tier 1 Capital Ratio available. Second, to make sure that the risk-weighted assets derived from these numbers are reliable, I keep only firm-year observations where the ratio of the two values of risk-weighted assets obtained from Total Capital/Total Capital Ratio and Tier 1 Capital/Tier 1 Capital Ratio is within the $[0.95,1.05]$ range, i.e. when the values obtained from the two ways of calculation are sufficiently close. ${ }^{41}$ Firm-year observations where

subordinated debt policy in the US request that banks issue subordinated debt to outside investors for it to have disciplinary effects (See, e.g. Kwast et al., 1999, Calomiris, 1999). I address potential issues associated with using unconsolidated accounts in Chapter V.

${ }^{41}$ For observations with available data on either Total Capital and Total Capital Ratio or Tier 1 Capital and Tier 1 Capital Ratio but not both, I check manually and delete an observation if reporting error is observed (e.g. the same numbers are reported for the capital and capital ratio). Besides, between the Total Capital and the Tier 1 Capital, it is much easier to check for the reliability of the reported Tier 1 Capital (its main components are voting common shareholders' equity and disclosed reserves or retained earnings, however, 
the subordinated debt amount is zero are automatically retained because the ratio of subordinated debt to risk-weighted assets is zero regardless of the value of risk-weighted assets. $^{42}$

Table II presents summary statistics of variables. In each sample, variables are winsorized at the $1^{\text {st }}$ and $99^{\text {th }}$ percentiles to lessen the influence of outliers. While the mean subordinated debt ratio may appear too small, $1.45 \%$ of risk-weighted assets and $1.09 \%$ of total liabilities, as mentioned earlier, proposals for a mandatory subordinated debt policy in the US typically suggest a required minimum ratio of $2 \%$ or $3 \%$ of riskweighted assets. For the subsample of banking firms with a positive subordinated debt ratio, ${ }^{43}$ the mean (median) value is $3.02 \%(2.86 \%$ ) of risk-weighted assets and $2.26 \%$ $(2.08 \%)$ of total liabilities.

Recall that subordinated debt is expected to provide market discipline only on banks that are clearly going concerns (Kwast el al., 1999). The natural logarithm of the zscore is used in the analysis; hence, by design, observations with non-positive raw zscore are dropped from the final sample. ${ }^{44}$ In addition, only $1.96 \%$ (1.62\%) of Sample I (II) has a z-score (measured in log) that is less than one (a z-score, measured in log, of one corresponds to return realization having to fall by approximately 2.72 standard deviations in order to deplete equity). Therefore, the vast majority of observations used in the analysis are from banking firms that are clearly going concerns.

Appendix B - Table A presents the distribution of subordinated debt issuers using Sample I, the larger sample, hence, more representative of subordinated debt issuers over the period under study. Only firm-year observations with a positive subordinated debt ratio (and other main variables available) are used. Over time, the number of firm-year observations with a positive subordinated debt ratio increases significantly in the second

other additions and subtractions are possible). Thus, I compute total risk-weighted assets as Tier 1 Capital divided by Tier 1 Capital Ratio for bank-year observations that remain in the sample.

${ }^{42}$ Approximately $75 \%$ of observations with available data on Total Capital and Total Capital Ratio and/or Tier 1 Capital and Tier 1 Capital Ratio (and other main data items) are retained. The results hold qualitatively if the $[0.90,1.10]$ range is used.

${ }^{43} 2,146$ observations (out of 4,442) in Sample I and 1,093 observations (out of 2,280) in Sample II have a positive subordinated debt ratio.

${ }^{44} 30$ (14) observations with non-positive raw z-score are dropped from Sample I (II) as a result. 
half of the period, and the ratio of subordinated debt to liabilities is slightly higher. Across countries, approximately $47.16 \%$ of observations with a positive subordinated debt ratio are associated with US banking firms. This, however, understates the size of subordinated debt markets outside the US and the potential for market discipline from such markets. Recall that this study examines only a subset of banking firms, namely, the publicly listed ones. In addition, the sample size is further constrained by the availability of the main variables used in the analysis. In the absence of these constraints, US banking firms account for approximately $41.76 \%$ of observations with a positive subordinated debt amount that are recorded in the Bankscope database over the period 2002-2007.

The sample used in the event study to estimate the average treatment effect on bank risk taking one year after the first subordinated debt issuance includes 1,759 observations, among them 286 are treated. Treated banks with no available data for the two years before the treatment are dropped from the sample for estimating the average treatment effect on bank risk taking one year before the first subordinated debt issuance. This sample consists of 1,549 observations, among them 264 are treated.

Appendix B - Table B shows the distribution of subordinated debt first issuances over the sample period of 2003-2007. Only a change in raw subordinated debt from zero to positive for the first time since 1996 is counted as first issuance. Other changes, such as from positive to zero to positive, from positive to missing to positive, from zero to missing to positive, from missing to positive, are ignored. The number of subordinated debt first issuances reported here for the period 2003-2007 is higher than the number of first issuances actually included in the matching analysis because the latter is subject to the availability of counterfactuals and data used for matching. Similarly, an observation used in forming the distribution of subordinated debt first issuances might not belong to the final Sample I if a main variable is not available in a given period. ${ }^{45}$ Over time, the number of first issuances is observed to have increased by an order of magnitude in 2005 . Across countries, the substantial increase in first issuances in 2005 is entirely accounted for by US banking firms. Overall, US firms account for about $82.72 \%$ of subordinated

\footnotetext{
${ }^{45}$ Recall that in regression analysis, independent variables are lagged by one year, while in the one-yearafter-the-first-issuance matching analysis, treated and controls are matched based on characteristics observed two years before the outcome.
} 
debt first issuances carried out by publicly listed banking firms around the world over the period 2003-2007.

Market and liquidity conditions do not decisively explain the surge in the US in 2005. Specifically, movements in the growth rate in industrial production, 5-year Treasury yields, and the CBOE and S\&P 500 Volatility Index are supposedly associated with lower credit spreads; on the other hand, movements in the slope of the yield curve, TED spread, and S\&P buy and hold return are supposedly associated with higher credit spreads.

Regarding banking regulations, there are tighter standards for trust preferred securities around the time the data shows increased subordinated debt issuances. These trust preferred securities are structured to count as Tier 1 capital by the bank supervisors but their payments are deductible from corporate income taxes as an interest expense. With tighter regulatory standards for trust preferred securities, it is possible that banking firms, in particular, the smaller ones, issue less trust preferred securities and start to issue more subordinated debt. ${ }^{46}$

\footnotetext{
${ }^{46}$ I thank Larry Wall for suggesting this substitution-effect explanation.
} 


\section{CHAPTER V}

\section{RESULTS}

\subsection{Regression analysis}

\subsubsection{Using ratio of subordinated debt to total risk-weighted assets}

In the first column of Table III, specification A is estimated using OLS. The coefficient on the ratio of subordinated debt to risk-weighted assets is significantly negative; however, it turns significantly positive in column 2 when 2 SLS is used. The test of endogeneity ${ }^{47}$ strongly rejects the null hypothesis of exogeneity of the ratio of subordinated debt to risk-weighted assets. In addition, the F-test of excluded instruments strongly rejects the hypothesis that the instruments could be excluded from the first-stage regression, and the Hansen $\mathrm{J}$ test of overidentification ${ }^{48}$ does not reject the null hypothesis that the instruments are uncorrelated with the disturbance process. Overall, the tests do not reject the validity of the suggested instruments. Further, the result supports the view that subordinated debt has a mitigating effect on banks' risk taking. Specifically, between two banks that start with the same levels of risk-weighted assets but have different amounts of subordinated debt on their balance sheets to support the riskweighted assets, the one with the higher amount of subordinated debt is associated with a higher distance to insolvency in the next period.

The economic size of the coefficient on the subordinated debt ratio is consequential. A one standard deviation increase in the subordinated debt ratio (from $1.45 \%$ to $3.26 \%$ ) is associated with an increase in the natural logarithm of z-score of 0.40 (from 3.77 to 4.17), which in turn is associated with a reduction in the upper bound of insolvency risk by $54.7 \%$ (from $0.053 \%$ to $0.024 \%$ ). Alternatively, under the assumption

\footnotetext{
${ }^{47}$ The test of endogeneity is a regression-based test (in STATA 10) which is robust to heteroskedasticity and clustering. With an unadjusted variance-covariance matrix of parameter estimates, this regressionbased test is identical to the Wu-Hausman test. The test involves fitting the model by both OLS and 2SLS approaches and comparing the resulting coefficient vectors. Under the null hypothesis of exogeneity the two estimates differ only due to sampling error. In contrast, under the alternative hypothesis of endogeneity, they should differ because the 2SLS estimator is consistent while the OLS estimator is not.

${ }^{48}$ In this test, the residuals from a 2 SLS regression are regressed on all exogenous variables (both included exogenous regressors and excluded instruments). Under the null hypothesis that all instruments are uncorrelated with the error term, this regression should have a population R2 value of zero.
} 
of normality of banks' returns, the result is an increase in the number of standard deviations that a return realization has to fall in order to deplete equity by $49.2 \%$ (from 43.38 to 64.72 ). Using the disclosure-insurance index in place of the private monitoring index in Column 3 produces an identical result since the pairwise correlation between the two indexes is above 0.99. Similar results are obtained when the bank regulation variables are not included in the model (Column 4 reports OLS estimates, and Column 5 uses 2SLS).

In Table IV, the sample is split at the median disclosure-insurance index, the median supervisory power index, and the median level of GDP per capita, ${ }^{49}$ respectively, to produce High and Low subsamples on the corresponding bank regulation index and economic development. The coefficient on subordinated debt to risk-weighted assets is positive and significant for all the High subsamples. The economic effect of having subordinated debt on the bank's balance sheet could be large. For example, using the coefficient on the subordinated debt ratio for the High subsample on supervisory power index (Panel A Column 4), a one standard deviation increase in the subordinated debt ratio (from $1.45 \%$ to $3.26 \%$ ) is associated with an increase in the natural logarithm of $\mathrm{z}$ score of 0.51 (from 3.77 to 4.28 ), which in turn is associated with a reduction in the upper bound of insolvency risk by $64.2 \%$ (from $0.053 \%$ to $0.019 \%$ ). Alternatively, under the assumption of normality of banks' returns, the result is an increase in the number of standard deviations that a return realization has to fall in order to deplete equity by $66.5 \%$ (from 43.38 to 72.24 ).

For the Low subsamples, the coefficient on subordinated debt to risk-weighted assets is insignificant; however, the test of endogeneity does not reject the null hypothesis of exogeneity of the ratio of subordinated debt to risk-weighted assets. The OLS estimates for the Low subsamples in Panel B also show that subordinated debt does not have a significant effect on bank risk taking. Panels $C$ and D report similar results when the bank regulation variables are excluded. Overall, the results are consistent with the

\footnotetext{
${ }^{49}$ Each country-year contributes to determining the cut-offs. As a country may move from the Low subsample to the High subsample or vice versa over time, the sum of the number of clusters for the High and Low subsamples is not necessarily equal to the number of countries. The cut-offs for bank regulations are the same if the country medians or the yearly medians are used in determining the corresponding sample medians. Using the country-survey year in determining the cut-offs yields the same cut-offs for bank regulations.
} 
prediction that there is some threshold level of national bank regulations and economic development above which subordinated debt could exert the desirable effect. ${ }^{50}$

\subsubsection{Using ratio of subordinated debt to total liabilities}

Table V reports the results obtained with Sample I. Once again, the evidence is consistent with subordinated debt having a mitigating effect on bank risk taking for the High subsamples. As the market discipline effect of subordinated debt is observed not only for banks that report the capital ratios, the paper's main results do not appear to be driven by sample selection.

\subsubsection{Sample selection}

Table VI reports the result of estimating specification $\mathrm{B}$. The coefficient on Report is insignificant in the outcome equation. Moreover, the null hypothesis that the correlation between the error term in the regression estimating the propensity to report the capital ratios and the error term in the outcome equation is zero is not rejected. Thus, a bank's choice of reporting the capital ratios does not appear to be correlated with its future risk taking, consequently, the results obtained with Sample II - the sample of banks that report the capital ratios - should not suffer from sample selection bias.

\subsubsection{Additional robustness checks}

I estimate a cross-section regression where explanatory variables are measured in (up to) 2006, and bank risk taking is averaged over 2007-2008. This is to check if the result is sensitive to the ownership measure. Table VII presents the results for both Samples I and II. The main results hold. Thus, it appears that banks having subordinated debt right before the financial crisis are comparatively more stable during the crisis period.

Among 53 countries in Sample II, the median US bank ranks $48^{\text {th }}$ with respect to size. This is due to the overwhelming presence of small and medium-sized US banks in the final sample (and of US banks in the database in the first place ${ }^{51}$ ). To check if the

\footnotetext{
${ }^{50}$ Similar results are obtained when the sample is split at the median level of financial development or legal development instead of the median level of economic development.

${ }^{51}$ The number of publicly listed Commercial Banks and Bank Holding Companies recorded in Bankscope at the end of 2008 that are from the US is almost half the total number.
} 
result is driven by this peculiarity, I restrict the number of US banks in the sample to 200 largest banking firms in terms of average size (large banks are also the primary targets of a mandatory subordinated debt policy). Of those, 181 banks have complete data on the main variables for at least one year. The resulting sample has 1,251 observations for 474 banking firms. Table VIII presents the result for this sample and carries the same message about the mitigating effect of subordinated debt on bank risk taking.

I address the issue that the regressions give more weight to countries with more observations by estimating a specification that weights each observation by the inverse of the number of observations from the same country and year. The result is reported in Table IX. For the High subsample on the disclosure-insurance index, the coefficient on subordinated debt ratio has the right sign but is not significant. For other High subsamples, the coefficient on subordinated debt ratio is statistically significant.

I also carry out the analysis separately for the US and the non-US subsamples. In particular, for the US subsample, as it is a one-country study, I am able to specify a firm fixed effect model. The key results hold qualitatively for both subsamples.

I assess potential issues associated with using unconsolidated financial statements in two ways. First, if other bank-level characteristics used in the analysis fail to capture systematic differences, if there is any, of banks with unconsolidated accounts, a dummy variable for these banks should mitigate this issue. The key results on subordinated debt hold in this specification (Appendix B - Table C, Panel A). Second, if subordinated debt issued by banks with unconsolidated accounts is not likely to exert the desirable effect on bank risk taking, e.g. because there is a possibility that the debt is issued to affiliated firms, these banks should be allowed both a different intercept and a different slope on the subordinated debt variable. Therefore, I extend the baseline specification with a dummy variable for banking firms with unconsolidated accounts and positive subordinated debt ratio, and an interaction term between this dummy and the subordinated debt ratio. This interaction term is treated as endogenous and is instrumented by the interaction terms between the dummy and each of the three variables: the average subordinated debt ratio of other banks in the same country, year and size group, the bank's lagged equity-to-assets ratio, and the bank's average tax rate. The key results hold for other banks. Moreover, the results also hold for banks with 
unconsolidated accounts and positive subordinated debt ratio, as the hypothesis that the sum of the coefficients on the subordinated debt ratio and on the interaction term is statistically zero is rejected in most cases (Appendix B - Table C, Panel B). Further, dropping banks with unconsolidated accounts and positive subordinated debt ratio does not affect the key results.

Finally, I check if the assumption of normality of banks' return holds in the data. As Bankscope imposes a constraint on coverage of individual banks' historical data (maximum of 16 years), it is not feasible to directly compare the frequency distribution of bank returns with that of a normal distribution. However, the Studentized Range (David et al., 1954) allows for normality testing for samples of at least 3 observations. Therefore, I collect return data for all publicly listed banking firms in Bankscope that have data available for at least 3 years and compute the Studentized Range (SR) for each bank. With a conservative approach of excluding SR values that are below the 0.10 fractile or that exceed the 0.90 fractile of the distribution of SR in samples of 3 or more from a normal distribution, $79.71 \%$ of banks in this extensive sample have SR values that are quite consistent with the hypothesis of normality. If only SR values that are below the 0.05 fractile or that exceed the 0.95 fractile are excluded, $87.92 \%$ of banks remain. The distribution of SR values for samples of banks that are actually used in the analysis is very similar to that for the above sample. The corresponding percentages for Sample I are $79.02 \%$ and $88.79 \%$; and the corresponding percentages for Sample II are $79.00 \%$ and $88.66 \%$. Overall, the data tells us that normality of banks' returns does not appear to be an unrealistic assumption. ${ }^{52}$ This, in turn, supports the discussion of the economic significance of having subordinated debt on bank risk taking carried out earlier where normality of banks' returns is assumed.

\subsubsection{Alternative measures of bank risk taking}

The results reported above are robust to using alternative measures of bank risk taking. For illustration, Table X Panel A Columns 1-3 and 4-6 report the results for baseline regressions using Sample II (similar to the ones in Table IV Panel A Columns 2, 4 , and 6) where the standard deviation of return and the earnings volatility replace $\mathrm{z}$-score

\footnotetext{
${ }^{52}$ The key results hold qualitatively when only banking firms from Sample II (I) that fit the normality assumption (with either approach of excluding SR values) are used in the analysis.
} 
as the dependent variable. Panel B reports results using Sample I. Higher subordinated debt ratio is associated with lower risk taking. Specifically, the subordinated debt ratio enters negatively and significantly for all the High subsamples. The test of endogeneity substantiates the endogeneity concern, and the F-test of excluded instruments strongly rejects the hypothesis that the instruments could be excluded from the first-stage regression in all cases. The Hansen $\mathrm{J}$ test of overidentification does not reject the null hypothesis that the instruments are uncorrelated with the disturbance process in most cases except for the High subsample on the disclosure-insurance index in Panel A. All other robustness tests produce qualitatively similar results. In sum, the results emphasize a robust relation between subordinated debt and bank risk taking.

\subsubsection{The impact of changes in subordinated debt on changes in bank risk taking over the same time period}

The conducted analysis examines the impact of the level of subordinated debt ratio on banks' future risk taking and utilizes within-countries across-banks variations. In this subsection, I investigate how a change in a bank's subordinated debt ratio affects the change in bank risk taking over the same period. The dependent variable is the change in risk taking from time $t-1$ to $t$. The change in subordinated debt ratio is measured over the same period. Control variables are measured at $\mathrm{t}-1$. The instruments for the change in subordinated debt ratio are the change in average subordinated debt ratio of other banks in the same country, year and size group, the change in the bank's lagged equity-to-assets ratio, and the change in the bank's average tax rate. The results are presented in Table XI. The dependent variable in Panel A is the change in $\mathrm{z}$-score, while in Panels B and C it is replaced by the change in standard deviation of return and the change in earnings volatility, respectively. The results are generally consistent with subordinated debt having a mitigating effect on bank risk taking. A positive change in the subordinated debt ratio is associated with a positive change in the z-score for the High subsample on economic development, while a positive change in the subordinated debt ratio is associated with a negative change in the standard deviation of return and the earnings volatility for the High subsamples on the disclosure-insurance index and economic development. The changes-on-changes regression has less power than the regressions in levels conducted 
earlier because it depends more on the limited within-banks variations in subordinated debt ratio.

\subsubsection{Other uninsured liabilities}

In principle, any uninsured bank obligation can potentially provide market discipline. Short-term uninsured liabilities subject banking firms to frequent exposure to market judgment. In fact, the interest rates paid on large, uninsured Certificate of Deposits (CD), have been found to be positively and significantly associated with accounting risk measures and examiners' ratings. Even the largest US banks, which would be perceived to be "too big to fail", were shown by Keeley (1990) and Ellis and Flannery (1992) to have risk premiums embedded in their CD rates. On the other hand, the long maturity of long-term uninsured liabilities magnifies the risk sensitivity of their holders, thus enhancing their incentives to monitor bank risk, and at the same time, provides the extra benefit of preventing runs on banks.

I investigate whether the mitigating effect of subordinated debt on banks' future risk taking is distinct from any potential effect of other uninsured liabilities by adding proxy variables for other types of uninsured debt to regression specification A. These variables are short-term uninsured debt, other long-term uninsured debt, or other uninsured debt which is the sum of the short-term and other long-term uninsured debt. All of these measures are normalized by the bank's total risk-weighted assets. Recall that Sample II keeps firm-year observations where the ratio of the two values of risk-weighted assets obtained from Total Capital/Total Capital Ratio and Tier 1 Capital/Tier 1 Capital Ratio is within the $[0.95,1.05]$ range, but automatically retains observations where the subordinated debt amount is zero because the ratio of subordinated debt to risk-weighted assets is zero regardless of the value of risk-weighted assets. However, in this subsection, due to the inclusion of other uninsured debt, all observations must satisfy the [0.95, 1.05] range condition ${ }^{53,54}$ (and have data on other uninsured liabilities available).

\footnotetext{
${ }^{53}$ Dropping from the final sample 148 observations from countries that answer "No" to both questions "Is there an explicit deposit insurance protection system?" and "Were insured depositors wholly compensated (to the extent of legal protection) the last time a bank failed?" does not change the result qualitatively.

${ }^{54}$ Using Sample I and normalizing uninsured debt by total liabilities produce qualitatively similar results.
} 
Table XII presents the results of estimating extended versions of specification A for each of the High subsamples. Conditioning on other uninsured liabilities, subordinated debt ratio continues to enter the z-score regression positively and significantly. In Columns 5-7 of each panel, like subordinated debt, the other uninsured debt is treated as endogenous, and is instrumented by the bank's lagged equity-to-assets ratio and its average tax rate. Banking firms are subject to capital regulation; hence a bank's leverage is likely to be related to its leverage in the previous period. And a higher tax rate means higher benefit from deduction of interest payments on debt. The key results on subordinated debt are robust to the ways other uninsured debt is treated. Higher subordinated debt is associated with lower future risk taking as evidenced by the positive and significant coefficient on subordinated debt ratio in the z-score regression, and negative and significant coefficients on subordinated debt ratio in the standard deviation of return and earnings volatility regressions. At the same time, other uninsured debt does not appear to have a mitigating effect on banks' future risk taking. In sum, subordinated debt, which stands out with its most junior status and a longer maturity than most large CDs and other uninsured bank liabilities, does appear to be the best choice for providing increased market discipline, as argued by advocates of increased use of subordinated debt as a market discipline instrument in banking firms.

\subsubsection{Bank-level corporate governance}

As mentioned in Chapter IV, for most countries participating in the World Bank surveys, subordinated debt is allowable, but not required, as a source of capital. Nevertheless, $48.31 \%$ (47.94\%) of firm-year observations in Sample I (II) have a positive subordinated debt ratio. A bank's decision on whether or not to issue subordinated debt and how much subordinated debt to have on its balance sheet could be interpreted as reflecting the bank's attempt to choose a level of monitoring that maximizes the bank's expected value. In this optimization problem, bank risk is subject to banking supervision, and a higher level of monitoring is plausibly associated with a lower level of default risk. Both the costs and the benefits of monitoring are factored into the bank's decision. On one hand, too much monitoring may hurt managerial initiative and consequently lower bank performance and worsen bank valuation. In addition, equity holders, due to the option-like feature of their claim, can have incentives to increase risk taking. On the other 
hand, a lower default probability provides certain benefits, e.g. in the form of reduced funding and operation costs.

In a broader context, a bank's choice of the level of monitoring by external investors is an aspect of the bank's corporate governance. Hence, there is a need to study the effect of subordinated debt in conjunction with the effect of other corporate governance practices. To ascertain whether subordinated debt has an independent, incremental effect on bank risk taking, in an extended version of the baseline regression specification, I control for the common corporate governance attributes, using constructed indexes that encompass board of directors, audit, anti-takeover, and managerial compensation/ownership.

As mentioned before, bank-level corporate governance data provided by the Institutional Shareholder Services (ISS) is available for US firms only. As a result, the analysis in this subsection is reduced to a one-country study. Out of 483 US banking firms in Sample II, 297 have governance data with a total of 779 observations. 8.7\% of these firms are in the S\&P 400, S\&P 500, or S\&P 600 indexes, 36.4\% in the Russell 3000, and the remaining 54.9\% outside the Russell 3000. Out of 593 US banking firms in Sample I, 360 have governance data with a total of 1,653 observations. $10.3 \%$ of these firms are in the S\&P 400, S\&P 500, or S\&P 600 indexes, 32.8\% in the Russell 3000, and the remaining $56.9 \%$ outside the Russell 3000. In both samples, compared to banks that do not have governance data, banks with governance data available on average are larger and issue more subordinated debt.

Table XIII presents the results of this one-country study. ${ }^{55}$ In Panel A, without firm fixed effects (but standard errors are clustered at the firm level), the key results on subordinated debt hold qualitatively when standard deviation of return and earnings volatility are used as risk measures, whether or not a governance measure is included in the regression. In other words, it does not appear that the observed effect of subordinated debt is absorbed by the governance measure. When z-score is used as the risk measure, the coefficient on subordinated debt ratio has the wrong sign and is marginally significant (it is insignificant with Sample I).

\footnotetext{
${ }^{55}$ I report the results where the governance index is expressed as a percentage. Results are qualitatively similar with alternative governance measures discussed in subsection 4.1.3.
} 
In Panel B, with firm fixed effects, subordinated debt ratio enters insignificantly in all cases, whether or not a governance measure is included in the regression. One potential explanation for this result is that the time dimension of the panel data used in this analysis is too limited with the average number of years being 2.6; this in effect renders the firm fixed effects model not suitable. For comparison, for the whole US sample which consists of both banks that have and that do not have governance data and for which the average number of years is 3.2 , the key results on subordinated debt hold qualitatively when firm fixed effects are included.

\subsubsection{When subordinated debt is not expected to exert market discipline effects}

I test the fourth hypothesis that the disciplinary effect of subordinated debt is expected to be nonexistent or, at most, weaker in too-big-to-fail banks and banks in which the government has a considerable stake by adding a dummy variable for too-bigto-fail/state-owned banks and an interaction term between the subordinated debt ratio and the too-big-to-fail/state-owned dummy in specification A. While the coefficient on the subordinated debt ratio is expected to be positive in the z-score regression, the coefficient on the interaction term between the subordinated debt ratio and the too-big-to-fail/stateowned dummy is expected to be negative so that overall there is a weaker or no market discipline effect of subordinated debt in too-big-to-fail/state-owned banking firms. The too-big-to-fail dummy takes value 1 if the bank's share in the country's total deposits exceeds $10 \%{ }^{56}$ The state-owned dummy takes value 1 if the largest shareholder of the bank is classified as a State or Public authority. The interaction term between the subordinated debt ratio and the too-big-to-fail/state-owned dummy, which is treated as endogenous because of the endogeneity of the subordinated debt measure, is instrumented by the interaction terms between the too-big-to-fail/state-owned dummy and each of the three variables: the average subordinated debt ratio of other banks in the same country, year and size group, the bank's lagged equity-to-assets ratio, and the bank's average tax rate.

\footnotetext{
${ }^{56}$ Caprio et al. (2007), Laeven and Levine (2009) define a bank as too-big-to-fail if the bank's share in the country's total deposits exceeds $10 \%$.
} 
The results of estimating these extended versions of specification A are reported in Table XIV and are generally consistent with the hypothesis that subordinated debt does not work as a market discipline instrument in too-big-to-fail and state-owned banks.

Specifically, in Panel A, while subordinated debt has a mitigating impact on risk taking, this effect is largely offset for state-owned banks. The null hypothesis that the sum of the coefficients on the subordinated debt ratio and on the interaction term between the subordinated debt ratio and the state-owned dummy is zero is not rejected in most cases. Panel B shows similar results for too-big-to-fail banks. As a robustness check, I also use different cutoffs for a bank's share in the country's total deposits to define too-big-to-fail banks, $15 \%$ in Panel C and $20 \%$ in Panel D. The results are consistent with the hypothesis.

\subsection{Event study}

Table XV Panels A and B present the results of estimating the average treatment effect on bank risk taking one year after and one year before the treatment, respectively. The results are reported for the High subsamples ${ }^{57}$ and for all three measures of bank risk taking. In each case, the number of matches is specified to be 1, 2, and 3. In Panel A, the results are robust when standard deviation of return is used as the measure of bank risk taking. The estimated average effect of issuing subordinated debt on issuing banks is always significant and in the right direction. Also, when matched with the nearest and second nearest non-issuing banks, issuing banks on average experience an increase in zscore one year later that is statistically significant in all cases except one. The result is weaker when earnings volatility is used as the measure of bank risk taking - the average treatment effect on treated banks is also in the right direction but not always significant. Overall, the results show that the average effect of issuing subordinated debt is a reduction in bank risk taking for issuing banks in the year after the issuance. This is consistent with the results obtained using regression analysis.

On the other hand, the results in Panel B do not support Niu (2008)'s model implication that banking firms reduce their risk before they issue subordinated debt. When $\mathrm{z}$-score is used as the outcome measure, the results even suggest that there is a

\footnotetext{
${ }^{57}$ The results for the Low subsamples are mostly insignificant and are not reported in a table.
} 
reduction in bank stability in the year before the issuance; however, when standard deviation of return and earnings volatility are used as measures of bank risk taking, the average effect of issuing subordinated debt on bank risk taking for issuing banks in the year before the issuance is not significantly different from zero. ${ }^{58}$ In sum, there is no evidence that banking firms reduce their risk taking in the year before they issue subordinated debt.

\footnotetext{
${ }^{58}$ When the outcome is specified to be the change in $\mathrm{z}$-score from year $\mathrm{t}-1$ to $t+1$, the average effect is a positive and significant change in $\mathrm{z}$-score for issuing firms.
} 


\section{CHAPTER VI}

\section{POLICY IMPLICATIONS}

Empirical results in the last chapter are consistent with subordinated debt exerting market discipline on banking firms. Market discipline may be imposed on banking firms whenever they choose to issue risk-sensitive subordinated debt; however, a policy that requires subordinated debt issuance would, in principle, enhance market discipline. Mandatory issuance ensures that a banking firm incurs higher cost of funds if it opts for higher risk and therefore may limit banking firm risk taking. Further, mandatory issuance compels disclosure to the market about the firm's current condition and future prospects, which refreshes secondary market prices. This, in turn, facilitates market and supervisory interpretations of the signals about banking firm risk. A subordinated debt requirement might also encourage some banks to boost their total capital ratios, thereby providing extra protection for the deposit insurance agency and tax payers.

However, a subordinated debt requirement might have adverse macroeconomic effects. First, setting the required level of subordinated debt capital at a higher share of risk weighted assets than banking firms would otherwise choose would raise the cost of financial intermediation (putting upward pressure on loan rates and downward pressure on deposit rates and profits), thereby causing a reduction in the level of intermediation and possibly a less efficient resource allocation. Second, given the subordinate status of subordinated debt, its cost would be more sensitive to economic conditions than that of other bank liabilities; as a result, bank lending might become more pro-cyclical with a subordinated debt requirement in place. ${ }^{59}$

Furthermore, a mandatory subordinated debt policy would impose additional private costs if it causes banking firms to substantially deviate from their existing debt composition. Rauh and Sufi (2010) show that, for non-financial firms, debt structure varies across the credit quality distribution. In particular, the lower the credit quality of

\footnotetext{
${ }^{59}$ Kwast et al. (1999) also discuss other potential costs. First, although subordinated debt holders cannot run, the signals provided by subordinated debt markets may encourage "runs" by other uninsured creditors with potential systemic risk implications; however, such a cost would be common to any requirements aiming at enhancing information disclosure and transparency. Second, a cost of all forms of market discipline is that they reduce the flexibility of supervisors at times when reduced flexibility appears to be a significant problem, i.e. when the value of regulatory discretion outweighs the cost of forbearance from a social perspective.
} 
the firm, the higher the spread of the types and priority structure of its debt. This is both a cross-sectional and within-firm phenomenon. They interpret the findings as consistent with optimal debt priority and composition being set to mitigate incentive conflicts. The study's implication is that a firm's optimal capital structure should be thought of not only in terms of the firm's leverage ratio, but also in terms of its debt composition. This in turn is relevant in the context of subordinated debt requirement for banking firms, since such a requirement could potentially lead to changes in banking firms' debt composition.

For the subsample of banking firms with a positive subordinated debt ratio, the mean (median) value is $3.02 \%(2.86 \%)$ of risk-weighted assets and $2.26 \%(2.08 \%)$ of total liabilities. A required subordinated debt ratio of $2 \%$ to $3 \%$ of risk-weighted assets, as typically suggested in mandatory subordinated debt policy proposals in the US, is quite close to the level currently chosen by banks that issue subordinated debt and, hence, is likely to make the above-mentioned adverse macroeconomic effects modest. Also, a mandatory policy that is based on existing market conventions may not cause banking firms to substantially deviate from their existing debt composition and/or impose an excessive regulatory burden on banking firms.

For countries with a relatively large number of banks in the sample, there is a positive correlation between bank size and the presence of subordinated debt on the bank's balance sheet. The mean (median) size of banking firms that issue subordinated debt is 5.58 (3.33) billion US dollars, while the corresponding number for banking firms that do not issue subordinated debt is 700.09 (619.08) million US dollars. Given that the larger banks have already voluntarily issued subordinated debt, applying a mandatory policy to large banks alone would reduce the cost of the requirement considerably. Also, with a required subordinated debt ratio of $2 \%$ to $3 \%$ of risk-weighted assets, it is likely that only large banks can issue subordinated debt in amounts sufficient to provide a liquid secondary market for the debt. ${ }^{60}$

\footnotetext{
${ }^{60}$ On the other hand, as pointed out in Lang and Robertson (2002), because most small banks rely heavily on insured deposits, are not publicly listed, and have not issued subordinated debt, they are subject to minimal amounts of market discipline. Therefore, applying a subordinated debt requirement to small banks would introduce market discipline where almost none exists. One way to make this feasible is to have subordinated debt issued by small banks be privately placed with institutional investors.
} 
While subordinated debt is potentially an important tool to enhance market discipline and mitigate excessive risk taking, it certainly cannot prevent excessive risk taking altogether, especially in the presence of distortions that undermine its effectiveness. For example, the analysis in subsection 5.1.9 shows that having subordinated debt in place is not associated with less risk taking in too-big-to-fail banks. The evidence does not necessarily downplay the role of subordinated debt in enhancing market discipline for the ultimate goal of reducing the likelihood of systemic risk, as destabilizing forces could arise from multiple smaller banks. However, it underscores the importance of serious consideration of a package of reforms that aim to stabilize the financial system and eliminate the too-big-to-fail issue.

One proposed reform is to have banks issue claims that behave like subordinated debt during normal times and automatically convert to additional equity when a bank's original shareholders' equity is depleted. These claims are referred to as reverse convertible debt or contingent capital. ${ }^{61}$ Reverse convertible debt is argued to (1) provide a transparent mechanism for un-levering a firm when it appears that the firm should have less debt in its capital structure, i.e. in bad times, but preserve the disciplinary effect and tax benefits of debt in good times; (2) generate lower bankruptcy costs through the automatic conversion of debt into equity, alleviate the debt overhang problem, and mitigate the negative signaling effect of equity issuance when these problems are most severe; and (3) decrease too-big-to-fail government assistance by reducing the likelihood of financial distress.

However, there are many complications with designing the triggers and conversion rules to make reverse convertible debt an effective cushion and to prevent potential for manipulation by investors or managers, especially close to times when the triggers are potentially reached. For example, a trigger which is specified on the bank's regulatory capital ratio would be subject to the problem of stale accounting data and political pressure; on the other hand, a market-valued trigger would rely on equity market efficiency, which can fail due to stock price manipulation and panic. As for conversion

\footnotetext{
${ }^{61}$ Prominent examples of contingent capital proposals are: Flannery (2005, 2009), McDonald (2009), French et al. (2010), Pennacchi (2010), Sundaresan and Wang (2010), Pennacchi et al. (2010). Over 20092010, Lloyds Banking Group, Rabobank, and Yorkshire Building Society have issued securities that might be broadly classified as contingent capital (Pennacchi et al., 2010).
} 
rules, assuming that the trigger is based on stock prices, conversion of contingent capital into equity at the bond's face value would create incentives for bondholders to short shares to trigger conversion; on the other hand, conversion of contingent capital into equity at a discount to the bond's face value might encourage higher risk taking and/or give managers/shareholders incentives to induce conversion as a means of selling equity cheaply. The Call Option Enhanced Reverse Convertibles (COERC) recently proposed by Pennacchi et al. (2010) force the firm to issue equity at a discount to bondholders when the firm is in financial distress but give equity holders the option to repay the debt to avoid dilutive conversion. As the risk of the debt holders is reduced, the debt instrument is more marketable than traditional reverse convertibles; and since shareholders can avoid the conversion by repaying the debt, they are not hurt by conversions driven by irrational stock price behavior or manipulation.

In addition to the operational complications, there are many other complications that arise with contingent capital. In particular, while automatic conversion allows distressed banks to bypass costly insolvency proceedings, when the bank is in difficulties, reverse convertible debt holders' attempts to sell it before the conditions for conversion arise might just shift frictions forward in time. Moreover, Hart and Zingales (2010b) point out that, by eliminating the threat of potential default, which forces restructuring of inefficient businesses and replacement of incompetent managers, reverse convertible debt may introduce more inefficiency in the banking sector. Finally, as argued by Admati et al. (2010), if the holders of reverse convertible debt are sufficiently important, government temptation to bail them out could be no less than it is for subordinated debt holders; in other words, if the main problem is the government's inability to refrain from bailing out creditors of financial institutions, reverse convertible debt is not expected to solve this problem.

Significantly raising the bank equity capital requirement is another recently proposed regulatory reform. Admati et al. (2010) argue that the observed high leverage of banks does not necessarily imply that debt is the socially optimal way to fund bank activities. Rather, it is because public policies, through taxes and government guarantees, subsidize debt financing. The resulting high leverage is socially harmful in view of the potential systemic risk that it brings about. Therefore, they suggest that regulators use 
significantly higher equity requirements to maintain the health and stability of the financial system. This could be achieved by limiting payouts and potentially mandating equity issuance by all regulated institutions for a period of time (to remove the negative signaling effect of equity issuance). It is argued that setting equity requirements significantly higher than the current level would entail large social benefits, as banking firms' current high leverage is the source of fragility and systemic risk.

However, given that public policies subsidize debt financing and that these policies are not expected to significantly change in a foreseeable future, a regulation that aims to change banking firms' capital structure substantially by way of significantly increasing the equity capital buffer could impose significant private costs on these banking firms as well as social costs. Specifically, as public policies in effect subsidize debt financing and penalize equity financing, a higher equity capital requirement raises banks' costs of funding. ${ }^{62}$ This in turn may lead to reduction of loan supply and economic growth. In addition, Kashyap et al. (2008) argue that high equity in good times gives managers significant discretion and provides opportunities for them to destroy value in negative net present value projects; hence, regulatory pressure to significantly increase bank equity capital may create agency problems. Also, any attempt to impose regulation against the interest of banks' shareholders will likely encourage regulatory arbitrage, where banking activities are moved out of the regulated part of the financial system and into the unregulated part, the so-called shadow banking system; the goal is to reduce banks' regulatory capital requirements with little or no reduction in their overall risks. This practice would render the regulation ineffective or even harmful.

Assuming that the proposed reform is operationally feasible, increased equity requirements and using subordinated debt are not necessarily mutually exclusive.

\footnotetext{
${ }^{62}$ Regarding the effect of increased equity requirements on banks' funding costs, Admati et al. (2010) make a valid point that when the bank is funded with more equity, a given fluctuation in earnings translates into a smaller fluctuation in return on equity, hence, the risk premium in the expected return on equity will be lower; further, if the additional equity capital serves to reduce the bank's bankruptcy risk, the interest rate on its debt will also be lower. Therefore, they conclude that increased capital requirements need not raise the bank's total funding costs. However, the observed high leverage of banking firms more likely imply that, from shareholders' perspective, in the presence of tax subsidies and underpriced explicit and implicit guarantees, the costs of increasing equity financing outweigh the benefits. Admati et al. (2010) also argue that if subsidies are necessary for some activities performed by banks, they should be given in ways that do not lead to excessive leverage. While the argument itself is valid, the feasibility of radically reforming public policies in a foreseeable future is in doubt.
} 
Additional equity can be added to banks' capital structure on top of existing deposits and subordinated debt. Doing so will further reduce incentives for risk-shifting without sacrificing the disciplining function of debt.

Finally, Poole (2009)'s reform proposal is for banks to maintain a substantial block of subordinated debt in their capital structure. Specifically, every bank must issue 10 -year subordinated debt equal to $10 \%$ of its liabilities. The bank must refinance onetenth of its subordinated debt every year or shrink otherwise. He further suggests that the US government restructure its existing support for banks by buying these banks' subordinated debt but keeping a senior status to other existing subordinated debt holders. While the specifics of this proposal are debatable, the suggested way of restructuring government support would allow the government to have a clear schedule for withdrawing federal special assistance and forcing banks to stand on their own. 


\section{CHAPTER VII}

\section{CONCLUSION}

In this study, I investigate (1) whether having subordinated debt in place mitigates bank risk taking and (2) whether national bank regulations and economic development affect the relation between subordinated debt and bank risk taking. Answers to these questions have important policy implications in view of growing concern among policy makers about banking firms' excessive risk taking and increasing interest in using subordinated debt as an instrument to augment market discipline of banking firms.

Using a variety of robustness tests, my study provides evidence supporting the view that subordinated debt has a mitigating effect on bank risk taking. The effect is consequential in the crisis period. Moreover, the risk mitigating effect appears to be a distinctive feature of subordinated debt as a type of bank obligation. The evidence thus supports proposals calling for increased use of subordinated debt in banking firms. In addition, the results are consistent with theories that the mitigating impact of subordinated debt on bank risk taking depends crucially on national bank regulations and economic development. Therefore, if a policy that requires subordinated debt as a part of banking firms' regulatory capital is to be implemented, it should be carried out in conjunction with creating necessary institutional conditions for subordinated debt to exert the intended effect on bank risk taking. 


\section{APPENDIX A}

TABLES

Table I: Variable Definition and Sources

\begin{tabular}{|c|c|c|}
\hline Variable & Definition & Source \\
\hline Z-score & $\begin{array}{l}\text { Distance to insolvency, equal to the return on average total } \\
\text { assets plus the equity capital-assets ratio divided by the } \\
\text { standard deviation of the return on average total assets } \\
\text { computed over a moving window of } 4 \text { years. The natural } \\
\text { logarithm of the z-score is used in the analysis }\end{array}$ & $\begin{array}{l}\text { Own calculation using } \\
\text { data from Bankscope }\end{array}$ \\
\hline Standard deviation of return & $\begin{array}{l}\text { Standard deviation of return on assets computed over a } \\
\text { moving window of } 4 \text { years }\end{array}$ & $\begin{array}{l}\text { Own calculation using } \\
\text { data from Bankscope }\end{array}$ \\
\hline Earnings volatility & $\begin{array}{l}\text { Standard deviation of the ratio of total earnings before taxes } \\
\text { and loan loss provisions to average total assets, computed } \\
\text { over a moving window of } 4 \text { years }\end{array}$ & $\begin{array}{l}\text { Own calculation using } \\
\text { data from Bankscope }\end{array}$ \\
\hline SND/RWA & $\begin{array}{l}\text { Ratio of subordinated debt to risk-weighted assets, where } \\
\text { the amount of risk-weighted assets is computed as Tier } 1 \\
\text { Capital divided by Tier } 1 \text { Capital Ratio }\end{array}$ & $\begin{array}{l}\text { Own calculation using } \\
\text { data from Bankscope }\end{array}$ \\
\hline $\mathrm{SND} / \mathrm{TL}$ & Ratio of subordinated debt to total liabilities & $\begin{array}{l}\text { Own calculation using } \\
\text { data from Bankscope }\end{array}$ \\
\hline $\begin{array}{l}\text { Bureau Van Dijk Independence } \\
\text { Indicator }\end{array}$ & $\begin{array}{l}\text { A dummy that takes value one if there is no shareholder } \\
\text { having more than } 25 \% \text { of direct or total ownership }\end{array}$ & Bankscope \\
\hline Demand deposits ratio & Ratio of demand deposits to total deposits & $\begin{array}{l}\text { Own calculation using } \\
\text { data from Bankscope }\end{array}$ \\
\hline Size & $\begin{array}{l}\text { The natural logarithm of total assets in thousands of US } \\
\text { dollars }\end{array}$ & $\begin{array}{l}\text { Own calculation using } \\
\text { data from Bankscope }\end{array}$ \\
\hline Loan growth & Growth in net loans with respect to previous year & Own calculation using \\
\hline
\end{tabular}


Loan loss provisions ratio

Liquidity ratio

Leverage

Lagged equity-to-assets ratio

Average SND ratio

Tax rate

Report

Accounting standard

Short-term uninsured debt

Other long-term uninsured debt

Other uninsured debt

State-owned dummy

Too-big-to-fail dummy

Governance index
Ratio of loan loss provisions to net interest income

Ratio of liquid assets to liquid liabilities

Ratio of total liabilities to total assets

Ratio of equity to total assets

The average SND ratio of other banks in the same country, year, and size group

Tax expense divided by profit before tax

A dummy variable that takes value 1 if the bank reports either the Total Capital Ratio and Total Capital or Tier 1 Capital Ratio and Tier 1 Capital, and zero otherwise A dummy variable that takes value 1 if the bank reports according to IAS, IFRS, Regulatory standard, or local GAAP (for US banks only), and zero otherwise

Deposits and short-term funding less total deposits, divided by risk-weighted assets (total liabilities)

Total other funding less SND, divided by risk-weighted assets (total liabilities)

Sum of short-term and other long-term uninsured debt

A dummy variable that takes value 1 if the largest shareholder of the bank is classified as a State, Public authority

A dummy variable that takes value 1 if the bank's share in the country's total deposits exceeds $10 \%$

Expressed as a percentage, where satisfying all 52 corporate data from Bankscope Own calculation using data from Bankscope Own calculation using data from Bankscope Own calculation using data from Bankscope Own calculation using data from Bankscope Own calculation using data from Bankscope Own calculation using data from Bankscope Own calculation using data from Bankscope

Own calculation using data from Bankscope

Own calculation using data from Bankscope Own calculation using data from Bankscope Own calculation using data from Bankscope

Own calculation using data from Bankscope

Own calculation using data from Bankscope and World Bank database

Own calculation using 
Private monitoring index

Disclosure-insurance index

Supervisory power index governance attributes in four broad categories: board of directors, audit, anti-takeover, and managerial compensation/ownership earns the bank an index of $100 \%$; if an attribute is missing then the index represents the percentage of non-missing attributes that are satisfied Sum of nine dummy variables that measure whether bank officials are legally liable for the accuracy of disclosed information; whether banks are required to produce consolidated financial statements, whether banks disclose information such as off-balance sheet items, accrued though unpaid interest/principal of non- performing loans and/or risk management procedures to the public; whether banks must be audited by certified external auditors; whether the largest ten banks are rated by international/domestic rating agencies; whether there is no explicit deposit insurance system and no insurance was paid the last time a bank failed; and whether subordinated debt is allowable/required as part of capital

A sub-index of the Private monitoring index. Sum of eight dummy variables that measure whether bank officials are legally liable for the accuracy of disclosed information; whether banks are required to produce consolidated financial statements, whether banks disclose information such as off-balance sheet items, accrued though unpaid interest/principal of non- performing loans and/or risk management procedures to the public; whether banks must be audited by certified external auditors; whether the largest ten banks are rated by international/domestic rating agencies; and whether there is no explicit deposit insurance system and no insurance was paid the last time a bank failed Sum of fourteen dummy variables that measure whether the supervisory agency has the right to meet with external auditors to discuss their report without the approval of the data from Institutional

Shareholder Services

Using World Bank

database and

methodology in Barth et

al. (2004)

Using World Bank

database and

methodology in Barth et

al. (2004)

\section{Using World Bank}

database and

methodology in Barth et 
bank; whether auditors are required by law to communicate directly to the supervisory agency any presumed

involvement of bank directors or senior managers in illicit activities, fraud, or insider abuse; whether supervisors can take action against external auditors for negligence; whether the supervisory authority can force a bank to change its internal organization structure; whether off-balance sheet items are disclosed to supervisors; whether the supervisory agency can order the bank's directors or management to constitute provisions to cover actual or potential losses; whether the supervisory agency can suspend the directors' decision to distribute (a) dividends (b) bonuses (c) management fees; whether the supervisory agency can legally declare - such that this declaration supersedes the rights of bank shareholders - that a bank is insolvent; whether the banking law gives authority to the supervisory agency to intervene, that is, suspend some or all ownership rights of a problem bank; regarding bank restructuring and reorganization, whether the supervisory agency or any other government agency (other than court) can do the following (a) supersede shareholder rights (b) remove and replace management (c) remove and replace directors

Sum of eight dummy variables that measure whether the minimum capital-asset ratio requirement is risk-weighted in line with the Basel guideline; whether the minimum ratio varies as a function of market risk; whether market value of loan losses not realized in accounting books are deducted; whether unrealized losses in securities portfolios are deducted; whether unrealized foreign exchange losses are deducted; whether the sources of funds to be used as capital are verified by the regulatory supervisory agency; whether the initial disbursement or subsequent injections of capital can be done with assets other than cash or government al. (2004)

Using World Bank

database and

methodology in Barth et

al. (2004) 
securities; whether the initial disbursement of capital can be done with borrowed funds

GDP per capita

Financial development

Rule of Law index
The natural logarithm of gross domestic product

The sum of stock market capitalization to GDP and total credit to the private sector as a share of GDP

The legal development index
World Development

Indicators

World Bank database

Kaufmann et al. (2008) 
Table II: Summary Statistics

Sample I

\begin{tabular}{lrrrr}
\hline \multicolumn{1}{c}{ Variable } & N & Mean & $\begin{array}{c}\text { Standard } \\
\text { deviation }\end{array}$ & Median \\
\hline Z-score & 4442 & 3.74 & 1.13 & 3.84 \\
Standard deviation of return, \% & 4442 & 0.47 & 0.90 & 0.21 \\
Earnings volatility, \% & 4426 & 0.51 & 0.75 & 0.27 \\
Size & 4442 & 14.46 & 2.03 & 13.94 \\
Demand deposits ratio, \% & 4442 & 24.34 & 21.10 & 17.01 \\
Loan growth, \% & 4442 & 19.76 & 26.91 & 13.11 \\
Loan loss provisions ratio, \% & 4442 & 10.31 & 17.03 & 6.07 \\
Liquidity ratio, \% & 4442 & 10.08 & 16.68 & 4.20 \\
Independence dummy & 4442 & 0.69 & 0.46 & 1.00 \\
SND/TL, \% & 4442 & 1.09 & 1.46 & 0.00 \\
Short-term uninsured debt, \% & 4442 & 5.39 & 6.73 & 2.78 \\
Other long-term uninsured debt, \% & 4442 & 6.49 & 7.13 & 4.11 \\
Other uninsured debt, \% & 4442 & 11.88 & 9.98 & 10.09 \\
State-owned dummy & 4442 & 0.03 & 0.18 & 0.00 \\
Too-big-to-fail dummy & 4303 & 0.13 & 0.33 & 0.00 \\
GDP per capita & 327 & 9.01 & 1.34 & 9.10 \\
Capital regulation index & 327 & 5.13 & 1.57 & 5.00 \\
Supervisory power index & 327 & 11.09 & 2.26 & 11.00 \\
Private monitoring index & 327 & 6.55 & 1.19 & 7.00 \\
Disclosure-insurance index & 327 & 5.57 & 1.14 & 6.00 \\
\hline & & & & \\
\hline
\end{tabular}

Sample II

\begin{tabular}{lrrrr}
\hline \multicolumn{1}{c}{ Variable } & N & Mean & $\begin{array}{r}\text { Standard } \\
\text { deviation }\end{array}$ & Median \\
\hline Z-score & 2280 & 3.77 & 1.11 & 3.85 \\
Standard deviation of return, \% & 2280 & 0.42 & 0.72 & 0.20 \\
Earnings volatility, \% & 2271 & 0.44 & 0.64 & 0.25 \\
Size & 2280 & 14.47 & 2.24 & 13.76 \\
Demand deposits ratio, \% & 2280 & 23.49 & 19.70 & 16.89 \\
Loan growth, \% & 2280 & 18.35 & 24.28 & 12.56 \\
Loan loss provisions ratio, \% & 2280 & 10.10 & 16.02 & 5.89 \\
Liquidity ratio, \% & 2280 & 9.40 & 14.71 & 4.32 \\
Independence dummy & 2280 & 0.72 & 0.45 & 1.00 \\
SND/RWA, \% & 2280 & 1.45 & 1.81 & 0.00 \\
Short-term uninsured debt, \% & 1793 & 6.94 & 9.53 & 3.01
\end{tabular}


Other long-term uninsured debt, $\%$

Other uninsured debt, $\%$

State-owned dummy

2189

14.75

14.86

10.30

Too-big-to-fail dummy

GDP per capita

171

0.03

0.11

0.17

0.00

Capital regulation index

171

9.48

0.31

0.00

Supervisory power index

171

5.29

1.31

9.83

Private monitoring index

Disclosure-insurance index

171

10.77

1.51

5.00

171

6.76

5.78

2.41

11.00

171

1.23

1.17

7.00

6.00 


\section{Table III: Subordinated Debt and Banks' Future Risk Taking}

The sample consists of 2,280 banking firm-year observations (Sample II) over the period 2002-2008. Dependent variable is z-score. Regressors are lagged by one year. Columns (1) and (4) report OLS estimates. Columns (2), (3), and (5) report 2SLS estimates. The IVs for SND/RWA are the average SND ratio of other banks in the same country, year, and size group, the lagged capital-to-assets ratio, and the average tax rate. See Table I for variable definition. Also included are the p-value of the regression-based test of endogeneity, the partial R2 of excluded instruments, the p-value of the F-test of excluded instruments, and the p-value of the Hansen $\mathbf{J}$ test of overidentification. Standard errors are clustered at the country level. For columns (1) and (4) t- statistics are reported in parentheses. For columns (2), (3), and (5), z-statistics are reported. *, **, and *** indicate significance at the 10\%, 5\%, and $1 \%$ levels, respectively.

\begin{tabular}{|c|c|c|c|c|c|}
\hline \multirow[t]{2}{*}{ Dependent variable: z-score } & OLS & IV & IV & OLS & IV \\
\hline & $(1)$ & $(2)$ & (3) & (4) & (5) \\
\hline SND/RWA & -.0735 & .2203 & .2203 & -.0739 & .2231 \\
\hline Loan growth & $\begin{array}{l}-.0079 \\
(3.84)^{* * * *}\end{array}$ & -.0090 & $\begin{array}{l}(2.52) \\
-.0090 \\
(320 * * *\end{array}$ & $\begin{array}{l}-.0078 \\
-0 * * *\end{array}$ & $\begin{array}{l}(2.56)^{* 4} \\
-.0090\end{array}$ \\
\hline \multirow[t]{2}{*}{ Size } & .0886 & $\begin{array}{l}(3.20) \\
-.0020\end{array}$ & $\begin{array}{l}(3.20) \\
-.0020\end{array}$ & .0880 & $\begin{array}{l}(3.18) \cdots 41 \\
-.0041\end{array}$ \\
\hline & $(2.06)^{* *}$ & $(0.13)$ & $(0.13)$ & $(2.02) * *$ & $(0.26)$ \\
\hline \multirow[t]{2}{*}{ Demand deposits ratio } & .0005 & .0010 & .0010 & .0006 & .0010 \\
\hline & $(0.15)$ & $(0.25)$ & $(0.25)$ & $(0.18)$ & $(0.27)$ \\
\hline \multirow[t]{2}{*}{ Independence dummy } & .1082 & .0470 & .0470 & .1085 & .0495 \\
\hline & $(2.35)^{* *}$ & $(1.12)$ & $(1.12)$ & $(2.35)^{* *}$ & (1.17) \\
\hline \multirow{2}{*}{ Loan loss provisions ratio } & -.0193 & -.0202 & -.0202 & -.0192 & -.0201 \\
\hline & $(3.49)^{* * * *}$ & $(3.10) * * *$ & $(3.10)^{* * * *}$ & $(3.50)^{* * * *}$ & $(3.11)^{* * * *}$ \\
\hline \multirow[t]{2}{*}{ Liquidity ratio } & -.0076 & -.0075 & -.0075 & -.0075 & -.0074 \\
\hline & $(1.81)^{*}$ & $(1.83) *$ & $(1.83)^{*}$ & $(1.77)^{*}$ & $(1.80)^{*}$ \\
\hline \multirow[t]{2}{*}{ GDP per capita } & .7531 & 1.262 & 1.262 & .7714 & 1.208 \\
\hline & $(2.13)^{* *}$ & $(4.67) * * *$ & $(4.67)^{* * * *}$ & $(2.26) * *$ & $(4.08)^{* * * *}$ \\
\hline \multirow[t]{2}{*}{ Capital regulation index } & -.0349 & -.0002 & -.0002 & & \\
\hline & $(0.59)$ & $(0.00)$ & $(0.00)$ & & \\
\hline \multirow{2}{*}{ Supervisory power index } & -.0646 & -.0576 & -.0576 & & \\
\hline & $(1.60)$ & $(1.57)$ & $(1.57)$ & & \\
\hline Private monitoring index & -.0236 & -.0912 & & & \\
\hline \multirow[t]{2}{*}{ Disclosure-insurance index } & $(0.53)$ & (1.56) & -.0912 & & \\
\hline & & & $(1.56)$ & & \\
\hline Country dummies & Yes & Yes & Yes & Yes & Yes \\
\hline Year dummies & Yes & Yes & Yes & Yes & Yes \\
\hline Number of clusters & 53 & 53 & 53 & 53 & 53 \\
\hline Observations & 2280 & 2271 & 2271 & 2280 & 2271 \\
\hline R-squared & 0.31 & & & 0.31 & \\
\hline Test of endogeneity (p-value) & & 0.0000 & 0.0000 & & 0.0000 \\
\hline Partial R2 of instruments & & 0.0576 & 0.0576 & & 0.0571 \\
\hline F-test of instruments (p-value) & & 0.0000 & 0.0000 & & 0.0000 \\
\hline Hansen J test (p-value) & & 0.5135 & 0.5135 & & 0.5142 \\
\hline
\end{tabular}




\section{Table IV: Impact of Bank Regulations and Economic Development on the Relation Between Subordinated Debt and Banks' Future Risk Taking}

The sample consists of 2,280 banking firm-year observations (Sample II) over the period 2002-2008. Dependent variable is z-score. Regressors are lagged by one year. In Panels A and C, regressions are estimated using 2SLS, where Columns (1), (3), and (5) report the results for the Low subsamples on Disclosure-insurance index (Low DI), Supervisory power index (Low SP), and Economic Development (Low ED), respectively; and Columns (2), (4), and (6) report the results for the High subsamples on Disclosure-insurance index (High DI), Supervisory power index (High SP), and Economic Development (High ED), respectively. In Panels B and D, regressions are estimated using OLS, where Columns (1), (2), and (3) report the results for the Low subsamples on Disclosure-insurance index (Low DI), Supervisory power index (Low SP), and Economic Development (Low ED), respectively. The IVs for SND/RWA are the average SND ratio of other banks in the same country, year, and size group, the lagged capital-to-assets ratio, and the average tax rate. See Table I for variable definition. Also included are the p-value of the regression-based test of endogeneity, the partial R2 of excluded instruments, the p-value of the F-test of excluded instruments, and the p-value of the Hansen J test of overidentification. Standard errors are clustered at the country level. For Panels A and C, z- statistics are reported in parentheses. For Panels B and D, t-statistics are reported. *, **, and *** indicate significance at the $10 \%, 5 \%$, and $1 \%$ levels, respectively.

\section{Panel A: IV Estimates}

\begin{tabular}{|c|c|c|c|c|c|c|}
\hline \multirow[t]{2}{*}{ Dependent variable: $\mathrm{z}$-score } & Low DI & High DI & Low SP & High SP & Low ED & High ED \\
\hline & $(1)$ & $(2)$ & (3) & (4) & $(5)$ & (6) \\
\hline SND/RWA & $\begin{array}{l}.0166 \\
(0.13)\end{array}$ & $\begin{array}{l}.2243 \\
(2.93)^{* * *}\end{array}$ & $\begin{array}{l}-.0673 \\
(1.10)\end{array}$ & $\begin{array}{l}.2833 \\
(10.57)^{* * *}\end{array}$ & $\begin{array}{l}.0041 \\
(0.04)\end{array}$ & $\begin{array}{l}.2954 \\
(3.63)^{* * * *}\end{array}$ \\
\hline Loan growth & $\begin{array}{l}.0006 \\
(0.38)\end{array}$ & $\begin{array}{l}-.0118 \\
(9.19)^{* * *}\end{array}$ & $\begin{array}{l}-.0027 \\
(1.04)\end{array}$ & $\begin{array}{l}-.0107 \\
(5.90)^{* * *}\end{array}$ & $\begin{array}{l}.0008 \\
(0.63)\end{array}$ & $\begin{array}{l}-.0122 \\
(13.68)^{* * *}\end{array}$ \\
\hline Size & $\begin{array}{l}-.1822 \\
(2.22)^{* *}\end{array}$ & $\begin{array}{l}.0028 \\
(0.17)\end{array}$ & $\begin{array}{l}-.0839 \\
(1.87)^{*}\end{array}$ & $\begin{array}{l}-.0091 \\
(0.83)\end{array}$ & $\begin{array}{l}-.0308 \\
(0.31)\end{array}$ & $\begin{array}{l}-.0227 \\
(1.44)\end{array}$ \\
\hline Demand deposits ratio & $\begin{array}{l}.0006 \\
(0.09)\end{array}$ & $\begin{array}{l}.0019 \\
(0.64)\end{array}$ & $\begin{array}{l}-.0007 \\
(0.23)\end{array}$ & $\begin{array}{l}.0064 \\
(3.02)^{* * *}\end{array}$ & $\begin{array}{l}.0059 \\
(0.80)\end{array}$ & $\begin{array}{l}.0010 \\
(0.22)\end{array}$ \\
\hline Independence dummy & $\begin{array}{l}-.0703 \\
(0.40)\end{array}$ & $\begin{array}{l}.0447 \\
(1.29)\end{array}$ & $\begin{array}{l}-.1178 \\
(1.21)\end{array}$ & $\begin{array}{l}.1003 \\
(2.06)^{* *}\end{array}$ & $\begin{array}{l}-.0290 \\
(0.22)\end{array}$ & $\begin{array}{l}.0271 \\
(0.69)\end{array}$ \\
\hline Loan loss provisions ratio & $\begin{array}{l}-.0046 \\
(1.04)\end{array}$ & $\begin{array}{l}-.0220 \\
(3.20)^{* * *}\end{array}$ & $\begin{array}{l}-.0094 \\
(2.87)^{* * *}\end{array}$ & $\begin{array}{l}-.0217 \\
(2.86)^{* * *}\end{array}$ & $\begin{array}{l}-.0103 \\
(3.95)^{* * *}\end{array}$ & $\begin{array}{l}-.0302 \\
(3.85)^{* * *}\end{array}$ \\
\hline Liquidity ratio & $\begin{array}{l}-.0002 \\
(0.03)\end{array}$ & $\begin{array}{l}-.0076 \\
(1.71)^{*}\end{array}$ & $\begin{array}{l}.0012 \\
(0.37)\end{array}$ & $\begin{array}{l}-.0128 \\
(5.55)^{* * *}\end{array}$ & $\begin{array}{l}-.0046 \\
(0.81)\end{array}$ & $\begin{array}{l}-.0079 \\
(1.84)^{*}\end{array}$ \\
\hline GDP per capita & $\begin{array}{l}.2617 \\
(0.66)\end{array}$ & $\begin{array}{l}.4524 \\
(0.53)\end{array}$ & $\begin{array}{l}.7912 \\
(1.55)\end{array}$ & $\begin{array}{l}.6887 \\
(1.05)\end{array}$ & $\begin{array}{l}1.496 \\
(2.17)^{* *}\end{array}$ & $\begin{array}{l}.4999 \\
(0.77)\end{array}$ \\
\hline Capital regulation index & $\begin{array}{l}-.0111 \\
(0.06)\end{array}$ & $\begin{array}{l}.0907 \\
(1.22)\end{array}$ & $\begin{array}{l}.1197 \\
(1.30)\end{array}$ & $\begin{array}{l}-.0407 \\
(0.45)\end{array}$ & $\begin{array}{l}-.1491 \\
(3.18)^{* * *}\end{array}$ & $\begin{array}{l}.126 \\
(2.09)^{* * *}\end{array}$ \\
\hline Supervisory power index & $\begin{array}{l}.1411 \\
(1.59)\end{array}$ & $\begin{array}{l}-.0043 \\
(0.07)\end{array}$ & $\begin{array}{l}.0148 \\
(0.36)\end{array}$ & $\begin{array}{l}.0747 \\
(0.55)\end{array}$ & $\begin{array}{l}.0688 \\
(1.21)\end{array}$ & $\begin{array}{l}-.1167 \\
(1.61)\end{array}$ \\
\hline Disclosure-insurance index & $\begin{array}{l}.2769 \\
(1.20)\end{array}$ & $\begin{array}{l}-.0174 \\
(0.07)\end{array}$ & $\begin{array}{l}-.0398 \\
(0.55)\end{array}$ & $\begin{array}{l}-.2737 \\
(2.87)^{* * * *}\end{array}$ & $\begin{array}{l}-.1144 \\
(2.64)^{* *}\end{array}$ & $\begin{array}{l}-.0416 \\
(0.23)\end{array}$ \\
\hline Country dummies & Yes & Yes & Yes & Yes & Yes & Yes \\
\hline
\end{tabular}




\begin{tabular}{llllll} 
Year dummies & Yes & Yes & Yes & Yes & Yes \\
\hline Number of clusters & 25 & 40 & 31 & 28 & 27 \\
Observations & 223 & 2048 & 509 & 1762 & 305 \\
Test of endogeneity (p-value) & 0.9201 & 0.0000 & 0.7980 & 0.0000 & 0.9254 \\
Partial R2 of instruments & 0.1603 & 0.0621 & 0.1646 & 0.0652 & 0.1167 \\
F-test of instruments (p-value) & 0.0056 & 0.0000 & 0.0001 & 0.0000 & 0.0000 \\
Hansen J test (p-value) & 0.4362 & 0.5310 & 0.3128 & 0.06467 & 0.0009 \\
\hline
\end{tabular}

\section{Panel B: OLS Estimates}

\begin{tabular}{|c|c|c|c|}
\hline \multirow[t]{2}{*}{ Dependent variable: $\mathrm{z}$-score } & Low DI & Low SP & Low ED \\
\hline & $(1)$ & $(2)$ & (3) \\
\hline SND/RWA & $\begin{array}{l}.0293 \\
(0.57)\end{array}$ & $\begin{array}{l}-.0441 \\
(1.46)\end{array}$ & $\begin{array}{l}.0229 \\
(0.60)\end{array}$ \\
\hline Loan growth & $\begin{array}{l}.0005 \\
(0.31)\end{array}$ & $\begin{array}{l}-.0026 \\
(1.00)\end{array}$ & $\begin{array}{l}.0010 \\
(0.82)\end{array}$ \\
\hline Size & $\begin{array}{l}-.1711 \\
(2.07)^{* *}\end{array}$ & $\begin{array}{l}-.0807 \\
(1.77)^{*}\end{array}$ & $\begin{array}{l}-.0225 \\
(0.22)\end{array}$ \\
\hline Demand deposits ratio & $\begin{array}{l}.0002 \\
(0.04)\end{array}$ & $\begin{array}{l}-.0007 \\
(0.22)\end{array}$ & $\begin{array}{l}.0064 \\
(0.90)\end{array}$ \\
\hline Independence dummy & $\begin{array}{l}-.1144 \\
(0.72)\end{array}$ & $\begin{array}{l}-.1301 \\
(1.37)\end{array}$ & $\begin{array}{l}-.0378 \\
(0.33)\end{array}$ \\
\hline Loan loss provisions ratio & $\begin{array}{l}-.0051 \\
(1.17)\end{array}$ & $\begin{array}{l}-.0105 \\
(3.09)^{* * *}\end{array}$ & $\begin{array}{l}-.0106 \\
(4.22)^{* * *}\end{array}$ \\
\hline Liquidity ratio & $\begin{array}{l}.0002 \\
(0.04)\end{array}$ & $\begin{array}{l}.0008 \\
(0.24)\end{array}$ & $\begin{array}{l}-.0050 \\
(1.02)\end{array}$ \\
\hline GDP per capita & $\begin{array}{l}.2699 \\
(0.69)\end{array}$ & $\begin{array}{l}.8611 \\
(1.73)^{*}\end{array}$ & $\begin{array}{l}1.290 \\
(1.85)^{*}\end{array}$ \\
\hline Capital regulation index & $\begin{array}{l}-.0168 \\
(0.09)\end{array}$ & $\begin{array}{l}.1096 \\
(1.18)\end{array}$ & $\begin{array}{l}-.1525 \\
(3.78)^{* * *}\end{array}$ \\
\hline Supervisory power index & $\begin{array}{l}.1388 \\
(1.62)\end{array}$ & $\begin{array}{l}.0077 \\
(0.19)\end{array}$ & $\begin{array}{l}.0632 \\
(1.14)\end{array}$ \\
\hline Disclosure-insurance index & $\begin{array}{l}.2664 \\
(1.18)\end{array}$ & $\begin{array}{l}-.0470 \\
(0.68)\end{array}$ & $\begin{array}{l}-.1053 \\
(2.69)^{* *}\end{array}$ \\
\hline Country dummies & Yes & Yes & Yes \\
\hline Year dummies & Yes & Yes & Yes \\
\hline Number of clusters & 26 & 32 & 27 \\
\hline Observations & 227 & 512 & 310 \\
\hline R-squared & 0.42 & 0.32 & 0.34 \\
\hline
\end{tabular}




\section{Panel C: IV Estimates}

\begin{tabular}{|c|c|c|c|c|c|c|}
\hline \multirow[t]{2}{*}{ Dependent variable: z-score } & Low DI & High DI & Low SP & High SP & Low ED & High ED \\
\hline & $(1)$ & $(2)$ & (3) & (4) & $(5)$ & $(6)$ \\
\hline SND/RWA & $\begin{array}{l}.0120 \\
(0.10)\end{array}$ & $\begin{array}{l}.2274 \\
(2.96)^{* * *}\end{array}$ & $\begin{array}{l}-.0618 \\
(1.01)\end{array}$ & $\begin{array}{l}.2800 \\
(10.28)^{* * *}\end{array}$ & $\begin{array}{l}-.0069 \\
(0.07)\end{array}$ & $\begin{array}{l}.2883 \\
(3.47)^{* * *}\end{array}$ \\
\hline Loan growth & $\begin{array}{l}.0004 \\
(0.28)\end{array}$ & $\begin{array}{l}-.0118 \\
(9.12)^{* * *}\end{array}$ & $\begin{array}{l}-.0027 \\
(1.07)\end{array}$ & $\begin{array}{l}-.0106 \\
(5.78) * * *\end{array}$ & $\begin{array}{l}.0011 \\
(0.94)\end{array}$ & $\begin{array}{l}-.0123 \\
(13.39)^{* * *}\end{array}$ \\
\hline Size & $\begin{array}{l}-.1643 \\
(2.17)^{* *}\end{array}$ & $\begin{array}{l}.0005 \\
(0.03)\end{array}$ & $\begin{array}{l}-.0889 \\
(1.91)^{*}\end{array}$ & $\begin{array}{l}-.0079 \\
(0.73)\end{array}$ & $\begin{array}{l}-.0383 \\
(0.38)\end{array}$ & $\begin{array}{l}-.0241 \\
(1.66)^{*}\end{array}$ \\
\hline Demand deposits ratio & $\begin{array}{l}-.0001 \\
(0.02)\end{array}$ & $\begin{array}{l}.0020 \\
(0.65)\end{array}$ & $\begin{array}{l}-.0006 \\
(0.21)\end{array}$ & $\begin{array}{l}.0065 \\
(3.17)^{* * *}\end{array}$ & $\begin{array}{l}.0054 \\
(0.74)\end{array}$ & $\begin{array}{l}.0011 \\
(0.26)\end{array}$ \\
\hline Independence dummy & $\begin{array}{l}-.0758 \\
(0.44)\end{array}$ & $\begin{array}{l}.0466 \\
(1.32)\end{array}$ & $\begin{array}{l}-.1082 \\
(1.09)\end{array}$ & $\begin{array}{l}.1002 \\
(2.05)^{* *}\end{array}$ & $\begin{array}{l}-.0140 \\
(0.11)\end{array}$ & $\begin{array}{l}.0366 \\
(0.97)\end{array}$ \\
\hline Loan loss provisions ratio & $\begin{array}{l}-.0052 \\
(1.30)\end{array}$ & $\begin{array}{l}-.0218 \\
(3.19)^{* * * *}\end{array}$ & $\begin{array}{l}-.0094 \\
(3.03)^{* * * *}\end{array}$ & $\begin{array}{l}-.0220 \\
(2.96)^{* * * *}\end{array}$ & $\begin{array}{l}-.0106 \\
(4.01)^{* * *}\end{array}$ & $\begin{array}{l}-.0292 \\
(3.63)^{* * *}\end{array}$ \\
\hline Liquidity ratio & $\begin{array}{l}-.0009 \\
(0.19)\end{array}$ & $\begin{array}{l}-.0077 \\
(1.73)^{*}\end{array}$ & $\begin{array}{l}.0010 \\
(0.32)\end{array}$ & $\begin{array}{l}-.0127 \\
(5.16)^{* * *}\end{array}$ & $\begin{array}{l}-.0065 \\
(1.21)\end{array}$ & $\begin{array}{l}-.0081 \\
(1.92)^{*}\end{array}$ \\
\hline GDP per capita & $\begin{array}{l}9757 \\
(2.18)^{* *}\end{array}$ & $\begin{array}{l}.5198 \\
(0.64)\end{array}$ & $\begin{array}{l}.9843 \\
(1.83)^{*}\end{array}$ & $\begin{array}{l}.5988 \\
(0.77)\end{array}$ & $\begin{array}{l}.9915 \\
(1.53)\end{array}$ & $\begin{array}{l}.0432 \\
(0.05)\end{array}$ \\
\hline Country dummies & Yes & Yes & Yes & Yes & Yes & Yes \\
\hline Year dummies & Yes & Yes & Yes & Yes & Yes & Yes \\
\hline Number of clusters & 25 & 40 & 31 & 28 & 27 & 31 \\
\hline Observations & 223 & 2048 & 509 & 1762 & 305 & 1966 \\
\hline Test of endogeneity (p-value) & 0.9018 & 0.0000 & 0.8929 & 0.0000 & 0.8985 & 0.0000 \\
\hline Partial R2 of instruments & 0.1608 & 0.0619 & 0.1562 & 0.0656 & 0.1222 & 0.0607 \\
\hline F-test of instruments (p-value) & 0.0066 & 0.0000 & 0.0002 & 0.0000 & 0.0005 & 0.0000 \\
\hline Hansen $\mathbf{J}$ test (p-value) & 0.4699 & 0.5389 & 0.3338 & 0.4687 & 0.9827 & 0.4930 \\
\hline
\end{tabular}




\section{Panel D: OLS Estimates}

\begin{tabular}{|c|c|c|c|}
\hline \multirow[t]{2}{*}{ Dependent variable: z-score } & Low DI & Low SP & Low ED \\
\hline & $(1)$ & $(2)$ & (3) \\
\hline SND/RWA & $\begin{array}{l}.0275 \\
(0.55)\end{array}$ & $\begin{array}{l}-.0466 \\
(1.46)\end{array}$ & $\begin{array}{l}.0167 \\
(0.43)\end{array}$ \\
\hline Loan growth & $\begin{array}{l}.0003 \\
(0.23)\end{array}$ & $\begin{array}{l}-.0026 \\
(1.03)\end{array}$ & $\begin{array}{l}.0014 \\
(1.11)\end{array}$ \\
\hline Size & $\begin{array}{l}-.1547 \\
(2.04)^{*}\end{array}$ & $\begin{array}{l}-.0849 \\
(1.80)^{*}\end{array}$ & $\begin{array}{l}-.0295 \\
(0.28)\end{array}$ \\
\hline Demand deposits ratio & $\begin{array}{l}-.0004 \\
(0.07)\end{array}$ & $\begin{array}{l}-.0006 \\
(0.20)\end{array}$ & $\begin{array}{l}.0059 \\
(0.83)\end{array}$ \\
\hline Independence dummy & $\begin{array}{l}-.1200 \\
(0.78)\end{array}$ & $\begin{array}{l}-.1155 \\
(1.19)\end{array}$ & $\begin{array}{l}-.0334 \\
(0.30)\end{array}$ \\
\hline Loan loss provisions ratio & $\begin{array}{l}-.0056 \\
(1.45)\end{array}$ & $\begin{array}{l}-.0104 \\
(3.28)^{* * *}\end{array}$ & $\begin{array}{l}-.0109 \\
(4.21)^{* * *}\end{array}$ \\
\hline Liquidity ratio & $\begin{array}{l}-.0005 \\
(0.13)\end{array}$ & $\begin{array}{l}.0006 \\
(0.20)\end{array}$ & $\begin{array}{l}-.0068 \\
(1.42)\end{array}$ \\
\hline GDP per capita & $\begin{array}{l}.9453 \\
(2.24)^{* *}\end{array}$ & $\begin{array}{l}1.017 \\
(1.85)^{*}\end{array}$ & $\begin{array}{l}.8427 \\
(1.26)\end{array}$ \\
\hline Country dummies & Yes & Yes & Yes \\
\hline Year dummies & Yes & Yes & Yes \\
\hline Number of clusters & 26 & 32 & 27 \\
\hline Observations & 227 & 512 & 310 \\
\hline R-squared & 0.41 & 0.32 & 0.32 \\
\hline
\end{tabular}




\section{Table V: Relation Between Subordinated Debt and Banks' Future Risk Taking - Sample Not Subject to Sample}

\section{Selection}

The sample consists of 4,442 banking firm-year observations (Sample I) over the period 2002-2008. Dependent variable is z-score. Regressors are lagged by one year. All regressions are estimated using 2SLS, where Columns (1) and (4) report the results for the High subsample on Disclosureinsurance index (High DI); Columns (2) and (5) report the results for the High subsample on Supervisory power index (High SP); and Columns (3) and (6) report the results for the High subsample on Economic development (High ED). The IVs for SND/TL are the average SND ratio of other banks in the same country, year, and size group, the lagged capital-to-assets ratio, and the average tax rate. See Table I for variable definition. Also included are the p-value of the regression-based test of endogeneity, the partial R2 of excluded instruments, the p-value of the F-test of excluded instruments, and the p-value of the Hansen J test of overidentification. Standard errors are clustered at the country level. z- statistics are reported in parentheses. *, **, and *** indicate significance at the $10 \%, 5 \%$, and $1 \%$ levels, respectively.

\begin{tabular}{|c|c|c|c|c|c|c|}
\hline \multirow[t]{2}{*}{ Dependent variable: $\mathrm{z}$-score } & High DI & High SP & High ED & High DI & High SP & High ED \\
\hline & $(1)$ & (2) & (3) & $(4)$ & $(5)$ & $(6)$ \\
\hline \multirow[t]{2}{*}{ SND/TL } & .3629 & .4028 & .3588 & .3616 & .3822 & .3505 \\
\hline & & $(2.47)^{* *}$ & $(3.64)^{* * *}$ & $(3.14)^{* * *}$ & $(2.57) * *$ & $(3.47)^{* * * *}$ \\
\hline \multirow[t]{2}{*}{ Loan growth } & -.0063 & -.0056 & -.0072 & -.0062 & -.0055 & $\begin{array}{l}-.0072 \\
-(508) * * *\end{array}$ \\
\hline & $(3.14)^{* * *}$ & $(2.40)^{* *}$ & $(5.15)^{* * *}$ & $(3.09) * * *$ & $(2.36)^{* * *}$ & $(5.08)^{* * * *}$ \\
\hline \multirow[t]{2}{*}{ Size } & -.0629 & -.0874 & -.0646 & -.0623 & -.0808 & -.0636 \\
\hline & $(1.76)^{*}$ & $(1.42)$ & $(2.32) * *$ & $(1.80)^{*}$ & $(1.44)$ & $(2.30) * *$ \\
\hline \multirow[t]{2}{*}{ Demand deposits ratio } & .0029 & .0044 & .0019 & .0029 & .0044 & .0021 \\
\hline & $(1.45)$ & $(2.17)^{* *}$ & $(0.79)$ & (1.45) & $(2.30)^{* *}$ & $(0.87)$ \\
\hline \multirow[t]{2}{*}{ Independence dummy } & .1524 & .2134 & .1669 & .1534 & .2146 & .1687 \\
\hline & $(2.55)^{* *}$ & $(4.15)^{* * *}$ & $(4.10)^{* * * *}$ & $(2.58)^{* * * *}$ & $(4.15)^{* * * *}$ & $(4.18) * * *$ \\
\hline \multirow[t]{2}{*}{ Loan loss provisions ratio } & $\begin{array}{l}-.0179 \\
(309) * * *\end{array}$ & -.0187 & -.0239 & -.0180 & -.0185 & -.0235 \\
\hline & $(3.09)^{* * *}$ & $(3.12)^{* * *}$ & $(3.54)^{* * *}$ & $(3.11)^{* * *}$ & $(3.09) * * *$ & $(3.40) * * *$ \\
\hline \multirow{2}{*}{ Liquidity ratio } & -.0041 & -.0072 & -.0027 & -.0041 & -.0073 & -.0028 \\
\hline & $(1.36)$ & $(3.35)^{* * *}$ & $(0.83)$ & (1.37) & $(3.37)^{* * * *}$ & $(0.86)$ \\
\hline \multirow[t]{2}{*}{ GDP per capita } & 1.569 & 1.861 & .6742 & 1.645 & 1.896 & .7725 \\
\hline & $(3.31)^{* * * *}$ & $(3.85)^{* * *}$ & $(1.07)$ & $(3.45) * * *$ & $(3.90)^{* * * *}$ & (1.13) \\
\hline Capital regulation index & -.0092 & -.0226 & -.0016 & & & \\
\hline \multirow{2}{*}{ Supervisory power index } & .0435 & . 1346 & $\begin{array}{l}(0.02) \\
-.1102\end{array}$ & & & \\
\hline & $(0.70)$ & $(1.70)^{*}$ & $(2.19)^{* *}$ & & & \\
\hline \multirow{2}{*}{ Disclosure-insurance index } & .0989 & -.2325 & .0604 & & & \\
\hline & $(0.29)$ & $(2.18)^{* *}$ & $(0.46)$ & & & \\
\hline Country dummies & Yes & Yes & Yes & Yes & Yes & Yes \\
\hline Year dummies & Yes & Yes & Yes & Yes & Yes & Yes \\
\hline Number of clusters & 55 & 46 & 50 & 55 & 46 & 50 \\
\hline Observations & 3879 & 3535 & 3690 & 3879 & 3535 & 3690 \\
\hline Test of endogeneity (p-value) & 0.0000 & 0.0051 & 0.0000 & 0.0000 & 0.0060 & 0.0000 \\
\hline Partial R2 of instruments & 0.0281 & 0.0192 & 0.0376 & 0.0284 & 0.0200 & 0.0391 \\
\hline F-test of instruments (p-value) & 0.0000 & 0.0007 & 0.0000 & 0.0000 & 0.0004 & 0.0000 \\
\hline Hansen J test (p-value) & 0.1369 & 0.2655 & 0.4558 & 0.1534 & 0.2779 & 0.4422 \\
\hline
\end{tabular}




\section{Table VI: Assessing Sample Selection}

The table reports full information maximum likelihood estimates of the treatment-effects selection model. The sample includes all banks with nonmissing values of z-score and explanatory variables for the period 2002-2008. Dependent variable in the first step is Report. Dependent variable in the second step is z-score. Regressors in the second step are lagged by one year. Also included is the p-value of the Wald test of independent equations. See Table I for variable definition. Standard errors are clustered at the country level.

Number of observations $=5125$

(Standard. error adjusted for 90 clusters in country)

\begin{tabular}{|c|c|c|c|c|c|c|}
\hline & Coefficient & Robust SE & $\mathrm{z}$ & p-value & \multicolumn{2}{|c|}{$95 \%$ Confidence interval } \\
\hline \multicolumn{7}{|l|}{ Z-score } \\
\hline Loan growth & -0.0025 & 0.0017 & -1.47 & 0.14 & -0.0059 & 0.0008 \\
\hline Size & 0.0425 & 0.0183 & 2.32 & 0.02 & 0.0066 & 0.0784 \\
\hline Demand deposits ratio & 0.0017 & 0.0017 & 0.97 & 0.33 & -0.0017 & 0.0051 \\
\hline Independence dummy & 0.1457 & 0.0526 & 2.77 & 0.01 & 0.0426 & 0.2488 \\
\hline Leverage & 0.0014 & 0.0049 & 0.28 & 0.78 & -0.0082 & 0.0110 \\
\hline Loan loss provisions ratio & -0.0086 & 0.0041 & -2.11 & 0.04 & -0.0165 & -0.0006 \\
\hline Liquidity ratio & -0.0050 & 0.0031 & -1.61 & 0.11 & -0.0110 & 0.0011 \\
\hline GDP per capita & 1.3250 & 0.2495 & 5.31 & 0.00 & 0.8360 & 1.8140 \\
\hline Report & -0.4286 & 0.4325 & -0.99 & 0.32 & -1.2762 & 0.4190 \\
\hline Country dummies & Yes & & & & & \\
\hline Year dummies & Yes & & & & & \\
\hline \multicolumn{7}{|l|}{ Report } \\
\hline Accounting standards & 1.3384 & 0.7035 & 1.90 & 0.06 & -0.0404 & 2.7173 \\
\hline Loan growth & 0.0023 & 0.0012 & 1.92 & 0.06 & 0.0000 & 0.0046 \\
\hline Size & 0.1868 & 0.0302 & 6.20 & 0.00 & 0.1277 & 0.2459 \\
\hline Demand deposits ratio & -0.0023 & 0.0034 & -0.67 & 0.50 & -0.0089 & 0.0044 \\
\hline Independence dummy & -0.1558 & 0.1929 & -0.81 & 0.42 & -0.5338 & 0.2222 \\
\hline Leverage & -0.0025 & 0.0092 & -0.27 & 0.78 & -0.0206 & 0.0155 \\
\hline Loan loss provisions ratio & 0.0012 & 0.0016 & 0.76 & 0.45 & -0.0019 & 0.0044 \\
\hline
\end{tabular}




\begin{tabular}{|c|c|c|c|c|c|c|}
\hline Liquidity ratio & -0.0041 & 0.0066 & -0.63 & 0.53 & -0.0170 & 0.0088 \\
\hline GDP per capita & -1.3877 & 0.6628 & -2.09 & 0.04 & -2.6868 & -0.0886 \\
\hline Country dummies & Yes & & & & & \\
\hline Year dummies & Yes & & & & & \\
\hline /athrho & 0.2602 & 0.2787 & 0.93 & 0.35 & -0.2861 & 0.8066 \\
\hline /Insigma & -0.0473 & 0.0393 & -1.20 & 0.23 & -0.1242 & 0.0296 \\
\hline rho & 0.2545 & 0.2607 & & & -0.2785 & 0.6677 \\
\hline sigma & 0.9538 & 0.0374 & & & 0.8832 & 1.0301 \\
\hline lambda & 0.2428 & 0.2573 & & & -0.2615 & 0.7471 \\
\hline Wald test of independent equations & $($ rho $=0)$ : & $\operatorname{chi} 2(1)=$ & 2.27 & & Prob. $>$ chi $2=$ & 0.1318 \\
\hline
\end{tabular}




\section{Table VII: Effect of Subordinated Debt on Bank Risk Taking During the Crisis Period}

The table reports the results of estimating cross-section regressions for Sample II (Columns 1-3) and Sample I (Columns 4-6). Dependent variable is zscore averaged over 2007-2008. Regressors are measured in 2006. All regressions are estimated using 2SLS, where Columns (1) and (4) report the results for the High subsamples on Disclosure-insurance index (High DI); Columns (2) and (5) report the results for the High subsamples on Supervisory power index (High SP); and Columns (3) and (6) report the results for the High subsamples on Economic development (High ED). The IVs for SND/RWA (SND/TL) are the average SND ratio of other banks in the same country, year, and size group, the lagged capital-to-assets ratio, and the average tax rate. See Table I for variable definition. Also included are the p-value of the regression-based test of endogeneity, the partial R2 of excluded instruments, the p-value of the F-test of excluded instruments, and the p-value of the Hansen J test of overidentification. Standard errors are clustered at the country level. z- statistics are reported in parentheses. ***, and *** indicate significance at the $10 \%, 5 \%$, and $1 \%$ levels, respectively.

\begin{tabular}{|c|c|c|c|c|c|c|}
\hline \multirow{3}{*}{ Dependent variable: $\mathrm{z}$-score } & \multicolumn{3}{|c|}{ Sample II } & \multicolumn{3}{|c|}{ Sample I } \\
\hline & High DI & High SP & High ED & High DI & High SP & High ED \\
\hline & $(1)$ & $(2)$ & (3) & $(4)$ & $(5)$ & $(6)$ \\
\hline SND/RWA (SND/TL) & $\begin{array}{l}.3163 \\
(5.85)^{* * *}\end{array}$ & $\begin{array}{l}.3642 \\
(6.03)^{* * *}\end{array}$ & $\begin{array}{l}.3173 \\
(5.43)^{* * *}\end{array}$ & $\begin{array}{l}.3266 \\
(4.69)^{* * *}\end{array}$ & $\begin{array}{l}.2989 \\
(4.18)^{* * *}\end{array}$ & $\begin{array}{l}.3884 \\
(4.55)^{* * *}\end{array}$ \\
\hline Loan growth & $\begin{array}{l}-.0129 \\
(8.14)^{* * *}\end{array}$ & $\begin{array}{l}-.0103 \\
(3.54)^{* * *}\end{array}$ & $\begin{array}{l}-.0115 \\
(5.86)^{* * *}\end{array}$ & $\begin{array}{l}-.0077 \\
(3.14)^{* * *}\end{array}$ & $\begin{array}{l}-.0061 \\
(2.08)^{* *}\end{array}$ & $\begin{array}{l}-.0093 \\
(5.26)^{* * *}\end{array}$ \\
\hline Size & $\begin{array}{l}-.1037 \\
(3.21)^{* * *}\end{array}$ & $\begin{array}{l}-.1334 \\
(6.75)^{* * *}\end{array}$ & $\begin{array}{l}-.1091 \\
(3.79)^{* * *}\end{array}$ & $\begin{array}{l}-.1106 \\
(3.78)^{* * *}\end{array}$ & $\begin{array}{l}-.1384 \\
(4.57) * * *\end{array}$ & $\begin{array}{l}-.1402 \\
(5.05)^{* * *}\end{array}$ \\
\hline Demand deposits ratio & $\begin{array}{l}.0125 \\
(4.61)^{* * *}\end{array}$ & $\begin{array}{l}.0155 \\
(5.40)^{* * *}\end{array}$ & $\begin{array}{l}.0082 \\
(1.63)\end{array}$ & $\begin{array}{l}.0084 \\
(3.63)^{* * *}\end{array}$ & $\begin{array}{l}.0118 \\
(5.03)^{* * *}\end{array}$ & $\begin{array}{l}.0065 \\
(2.24)^{* *}\end{array}$ \\
\hline Independence dummy & $\begin{array}{l}-.0056 \\
(0.09)\end{array}$ & $\begin{array}{l}-.0044 \\
(0.07)\end{array}$ & $\begin{array}{l}-.0246 \\
(0.39)\end{array}$ & $\begin{array}{l}.0618 \\
(0.73)\end{array}$ & $\begin{array}{l}.0772 \\
(0.91)\end{array}$ & $\begin{array}{l}.0580 \\
(1.34)\end{array}$ \\
\hline Loan loss provisions ratio & $\begin{array}{l}-.0184 \\
(2.64) * * *\end{array}$ & $\begin{array}{l}-.0202 \\
(2.65)^{* * * *}\end{array}$ & $\begin{array}{l}-.0323 \\
(1.70)^{*}\end{array}$ & $\begin{array}{l}-.0181 \\
(2.45)^{* *}\end{array}$ & $\begin{array}{l}-.0202 \\
(2.75)^{* * * *}\end{array}$ & $\begin{array}{l}-.0282 \\
(1.97)^{* *}\end{array}$ \\
\hline Liquidity ratio & $\begin{array}{l}.0005 \\
(0.15)\end{array}$ & $\begin{array}{l}-.0032 \\
(0.98)\end{array}$ & $\begin{array}{l}-.0009 \\
(0.27)\end{array}$ & $\begin{array}{l}.0016 \\
(0.52)\end{array}$ & $\begin{array}{l}-.0079 \\
(1.84)^{*}\end{array}$ & $\begin{array}{l}.0020 \\
(0.60)\end{array}$ \\
\hline Country dummies & Yes & Yes & Yes & Yes & Yes & Yes \\
\hline Number of clusters & 30 & 21 & 24 & 41 & 32 & 37 \\
\hline Observations & 477 & 394 & 446 & 732 & 637 & 689 \\
\hline Test of endogeneity (p-value) & 0.0000 & 0.0000 & 0.0000 & 0.0030 & 0.0014 & 0.0000 \\
\hline Partial R2 of instruments & 0.0889 & 0.0969 & 0.0848 & 0.0562 & 0.0505 & 0.0832 \\
\hline F-test of instruments (p-value) & 0.0000 & 0.0000 & 0.0000 & 0.0000 & 0.0000 & 0.0000 \\
\hline Hansen J test (p-value) & 0.1718 & 0.2851 & 0.1030 & 0.2117 & 0.1592 & 0.4085 \\
\hline
\end{tabular}




\section{Table VIII: Relation Between Subordinated Debt and Banks' Future Risk Taking - Reduced Sample}

The table reports the results for a subset of Sample II, where the number of US banks in the sample is restricted to 181 largest banks in terms of average size. Dependent variable is z-score. Regressors are lagged by one year. All regressions are estimated using 2SLS, where Columns (1) and (4) report the results for the High subsample on Disclosure-insurance index (High DI); Columns (2) and (5) report the results for the High subsample on Supervisory power index (High SP); and Columns (3) and (6) report the results for the High subsample on Economic development (High ED). The IVs for SND/RWA are the average SND ratio of other banks in the same country, year, and size group, the lagged capital-to-assets ratio, and the average tax rate. See Table I for variable definition. Also included are the p-value of the regression-based test of endogeneity, the partial R 2 of excluded instruments, the p-value of the F-test of excluded instruments, and the p-value of the Hansen J test of overidentification. Standard errors are clustered at the country level. z- statistics are reported in parentheses. ***, and *** indicate significance at the 10\%, 5\%, and $1 \%$ levels, respectively.

\begin{tabular}{|c|c|c|c|c|c|c|}
\hline \multirow[t]{2}{*}{ Dependent variable: z-score } & High DI & High SP & High ED & High DI & High SP & High ED \\
\hline & $(1)$ & $(2)$ & (3) & (4) & $(5)$ & (6) \\
\hline SND/RWA & $\begin{array}{l}.2674 \\
(236) * *\end{array}$ & $\begin{array}{l}.3542 \\
.562) * * *\end{array}$ & .3379 & .2714 & $\begin{array}{l}.3520 \\
(574 * * * *\end{array}$ & .3443 \\
\hline \multirow{2}{*}{ Loan growth } & -.0034 & -.0003 & $\begin{array}{l}(2.80) \\
-.0040\end{array}$ & $\begin{array}{l}-.0035 \\
-.099\end{array}$ & -.0002 & $\begin{array}{l}(3.14) \\
-.0042\end{array}$ \\
\hline & $(1.62)$ & $(0.10)$ & $(1.76)^{*}$ & $(1.63)$ & $(0.08)$ & $(1.83)^{*}$ \\
\hline \multirow[t]{2}{*}{ Size } & -.1031 & -.1390 & -.1337 & -.1049 & -.1382 & -.1400 \\
\hline & $(2.48)^{* *}$ & $(4.24)^{* * * *}$ & $(3.94)^{* * *}$ & $(2.55)^{* *}$ & $(4.19)^{* * *}$ & $(4.45) * * *$ \\
\hline \multirow[t]{2}{*}{ Demand deposits ratio } & .0026 & .0111 & .0012 & .0026 & .0113 & .0014 \\
\hline & $(0.68)$ & $(2.32)^{* *}$ & $(0.23)$ & $(0.69)$ & $(2.48)^{* *}$ & $(0.27)$ \\
\hline \multirow[t]{2}{*}{ Independence dummy } & .1093 & .3391 & .1463 & .1090 & .3349 & .1547 \\
\hline & $(0.86)$ & $(4.81)^{* * * *}$ & $(0.99)$ & $(0.86)$ & $(4.84) * * *$ & (1.09) \\
\hline \multirow[t]{2}{*}{ Loan loss provisions ratio } & -.0150 & -.0134 & -.0222 & -.0150 & -.0138 & -.0213 \\
\hline & $(4.19)^{* * *}$ & $(3.54)^{* * *}$ & $(3.09)^{* * *}$ & $(4.21)^{* * *}$ & $(3.85)^{* * *}$ & $(3.01)^{* * *}$ \\
\hline \multirow[t]{2}{*}{ Liquidity ratio } & -.0016 & -.0048 & -.0018 & -.0016 & -.0045 & -.0018 \\
\hline & $(0.63)$ & $(2.81)^{* * * *}$ & $(0.77)$ & $(0.63)$ & $(2.55)^{* *}$ & $(0.80)$ \\
\hline \multirow[t]{2}{*}{ GDP per capita } & 1.551 & 1.352 & 1.561 & 1.755 & 1.354 & 1.301 \\
\hline & $(1.88)^{*}$ & $(2.36) * *$ & $(2.17)^{* *}$ & $(2.26)^{* * *}$ & $(1.88)^{*}$ & $(1.64)$ \\
\hline \multirow[t]{2}{*}{ Capital regulation index } & .0180 & .0424 & .0696 & & & \\
\hline & $(0.35)$ & $(0.43)$ & $(0.94)$ & & & \\
\hline \multirow{2}{*}{ Supervisory power index } & .0132 & .0747 & -.0806 & & & \\
\hline & $(0.18)$ & $(0.64)$ & $(1.02)$ & & & \\
\hline \multirow[t]{2}{*}{ Disclosure-insurance index } & .1470 & -.3433 & -.0744 & & & \\
\hline & $(0.59)$ & $(4.23)^{* * *}$ & $(0.33)$ & & & \\
\hline Country dummies & Yes & Yes & Yes & Yes & Yes & Yes \\
\hline Year dummies & Yes & Yes & Yes & Yes & Yes & Yes \\
\hline Number of clusters & 40 & 28 & 31 & 40 & 28 & 31 \\
\hline Observations & 1019 & 733 & 937 & 1019 & 733 & 937 \\
\hline Test of endogeneity (p-value) & 0.0001 & 0.0000 & 0.0000 & 0.0002 & 0.0000 & 0.0000 \\
\hline Partial R2 of instruments & 0.0856 & 0.0704 & 0.0819 & 0.0802 & 0.0683 & 0.0749 \\
\hline F-test of instruments (p-value) & 0.0000 & 0.0000 & 0.0000 & 0.0000 & 0.0000 & 0.0000 \\
\hline Hansen J test (p-value) & 0.8584 & 0.3277 & 0.5796 & 0.9175 & 0.2766 & 0.3893 \\
\hline
\end{tabular}




\section{Table IX: Relation Between Subordinated Debt and Banks' Future Risk Taking - Weighted Estimation}

The sample consists of 2,280 banking firm-year observations (Sample II) over the period 2002-2008. Dependent variable is z-score. Regressors are lagged by one year. Each observation is weighted by the inverse of the number of observations from the same country and year. All regressions are estimated using 2SLS, where Columns (1) and (4) report the results for the High subsample on Disclosure-insurance index (High DI); Columns (2) and (5) report the results for the High subsample on Supervisory power index (High SP); and Columns (3) and (6) report the results for the High subsample on Economic development (High ED). The IVs for SND/RWA are the average SND ratio of other banks in the same country, year, and size group, the lagged capital-to-assets ratio, and the average tax rate. See Table I for variable definition. Also included are the partial R2 of excluded instruments, the p-value of the F-test of excluded instruments, and the p-value of the Hansen $\mathbf{J}$ test of overidentification. Standard errors are clustered at the country level. z- statistics are reported in parentheses. *,**, and *** indicate significance at the 10\%, 5\%, and $1 \%$ levels, respectively.

\begin{tabular}{|c|c|c|c|c|c|c|}
\hline \multirow[t]{2}{*}{ Dependent variable: z-score } & High DI & High SP & High ED & High DI & High SP & High ED \\
\hline & $(1)$ & $(2)$ & (3) & $(4)$ & $(5)$ & $(6)$ \\
\hline SND/RWA & $\begin{array}{l}.1254 \\
(1.59)\end{array}$ & $\begin{array}{l}.3455 \\
(2.05)^{* *}\end{array}$ & $\begin{array}{l}.2444 \\
(1.72)^{*}\end{array}$ & $\begin{array}{l}.1068 \\
(1.25)\end{array}$ & $\begin{array}{l}.2804 \\
(1.93)^{*}\end{array}$ & $\begin{array}{l}.2512 \\
(1.68)^{*}\end{array}$ \\
\hline \multirow[t]{2}{*}{ Loan growth } & -.0016 & .0038 & .0008 & -.0021 & .0038 & .0013 \\
\hline & $(0.56)$ & $(1.62)$ & $(0.17)$ & $(0.72)$ & $(1.64)$ & $(0.27)$ \\
\hline \multirow{2}{*}{ Size } & .0027 & .0076 & -.0950 & .0096 & .0217 & -.0946 \\
\hline & $(0.04)$ & $(0.08)$ & $(1.54)$ & $(0.15)$ & $(0.25)$ & $(1.55)$ \\
\hline Demand deposits ratio & .0020 & .0113 & -.0002 & .0029 & .0119 & -.0001 \\
\hline \multirow[t]{2}{*}{ Independence dummy } & .1303 & .3630 & .1499 & .1280 & .3813 & .1497 \\
\hline & $(0.87)$ & $(1.64)$ & $(0.89)$ & $(0.87)$ & $(1.94)^{*}$ & $(0.88)$ \\
\hline \multirow[t]{2}{*}{ Loan loss provisions ratio } & -.0108 & -.0078 & -.0180 & -.0113 & -.0086 & -.0184 \\
\hline & $(3.84)^{* * * *}$ & $(2.26)^{* *}$ & $(3.92)^{* * *}$ & $(3.97)^{* * * *}$ & $(3.01)^{* * *}$ & $(3.78) * * *$ \\
\hline \multirow[t]{2}{*}{ Liquidity ratio } & -.0002 & -.0036 & -.0012 & -.0002 & -.0021 & -.0017 \\
\hline & $(0.05)$ & $(0.56)$ & $(0.32)$ & $(0.07)$ & $(0.36)$ & $(0.45)$ \\
\hline \multirow[t]{2}{*}{ GDP per capita } & 1.394 & 1.163 & .2236 & 1.191 & 1.140 & .3785 \\
\hline & $(1.90)^{*}$ & $(2.05) * *$ & $(0.27)$ & $(1.53)$ & $(1.73)^{*}$ & $(0.50)$ \\
\hline \multirow{2}{*}{ Capital regulation index } & -.1442 & -.2184 & .0203 & & & \\
\hline & $(1.29)$ & $(1.32)$ & $(0.21)$ & & & \\
\hline Supervisory power index & -.0106 & -.0040 & -.0526 & & & \\
\hline Disclosure-insurance index & $(0.91)$ & $(1.94)^{*}$ & $(1.01)$ & & & \\
\hline Country dummies & Yes & Yes & Yes & Yes & Yes & Yes \\
\hline Year dummies & Yes & Yes & Yes & Yes & Yes & Yes \\
\hline Number of clusters & 40 & 28 & 31 & 40 & 28 & 31 \\
\hline Observations & 2048 & 1762 & 1966 & 2048 & 1762 & 1966 \\
\hline Partial R2 of instruments & 0.1648 & 0.1421 & 0.1573 & 0.1557 & 0.1363 & 0.1581 \\
\hline F-test of instruments (p-value) & 0.0001 & 0.0022 & 0.0037 & 0.0001 & 0.0038 & 0.0031 \\
\hline Hansen J test (p-value) & 0.3032 & 0.2994 & 0.2421 & 0.3354 & 0.2215 & 0.2831 \\
\hline
\end{tabular}




\section{Table X: Alternative Measures of Bank Risk Taking}

In Panel A, the sample consists of 2,280 banking firm-year observations (Sample II) over the period 2002-2008. In Panel B, the sample consists of 4,442 banking firm-year observations (Sample I) over the same period. Dependent variable is standard deviation of return in Columns (1)-(3), and earnings volatility in Columns (4)-(6). Regressors are lagged by one year. All regressions are estimated using 2SLS, where Columns (1) and (4) report the results for the High subsample on Disclosure-insurance index (High DI); Columns (2) and (5) report the results for the High subsample on Supervisory power index (High SP); and Columns (3) and (6) report the results for the High subsample on Economic development (High ED). The IVs for SND/RWA (SND/TL) are the average SND ratio of other banks in the same country, year, and size group, the lagged capital-to-assets ratio, and the average tax rate. See Table I for variable definition. Also included are the p-value of the regression-based test of endogeneity, the partial R2 of excluded instruments, the p-value of the F-test of excluded instruments, and the p-value of the Hansen J test of overidentification. Standard errors are clustered at the country level. z- statistics are reported in parentheses. $* * *$, and $* * *$ indicate significance at the $10 \%, 5 \%$, and $1 \%$ levels, respectively.

Panel A: Sample II (2,280 banking firm-year observations over the period 2002-2008)

\begin{tabular}{|c|c|c|c|c|c|c|}
\hline \multirow{3}{*}{ Dependent variable: } & \multicolumn{3}{|c|}{ Standard deviation of return } & \multicolumn{3}{|c|}{ Earnings volatility } \\
\hline & High DI & High SP & High ED & High DI & High SP & High ED \\
\hline & $(1)$ & $(2)$ & (3) & $(4)$ & $(5)$ & (6) \\
\hline SND/RWA & $\begin{array}{l}-1.038 \\
(4.80)^{* * *}\end{array}$ & $\begin{array}{l}-1.173 \\
(19.87)^{* * *}\end{array}$ & $\begin{array}{l}-1.113 \\
(5.93)^{* * *}\end{array}$ & $\begin{array}{l}-.9145 \\
(5.58)^{* * * *}\end{array}$ & $\begin{array}{l}-.9898 \\
(20.51)^{* * *}\end{array}$ & $\begin{array}{l}-.9960 \\
(7.88)^{* * * *}\end{array}$ \\
\hline Loan growth & $\begin{array}{l}.0142 \\
(5.31)^{* * * *}\end{array}$ & $\begin{array}{l}.0139 \\
(5.20) * * *\end{array}$ & $\begin{array}{l}.0148 \\
(7.52)^{* * * *}\end{array}$ & $\begin{array}{l}.0137 \\
(6.24)^{* * * *}\end{array}$ & $\begin{array}{l}.0130 \\
(5.95) * * *\end{array}$ & $\begin{array}{l}.0142 \\
(8.71)^{* * * *}\end{array}$ \\
\hline Size & $\begin{array}{l}.2770 \\
(2.54)^{* *}\end{array}$ & $\begin{array}{l}.3575 \\
(10.95) * * *\end{array}$ & $\begin{array}{l}.3009 \\
(2.96)^{* * * *}\end{array}$ & $\begin{array}{l}.2355 \\
(2.60)^{* * * *}\end{array}$ & $\begin{array}{l}.2956 \\
(11.94) * * *\end{array}$ & $\begin{array}{l}.2609 \\
(3.24)^{* * * *}\end{array}$ \\
\hline Demand deposits ratio & $\begin{array}{l}-.0001 \\
(0.03)\end{array}$ & $\begin{array}{l}-.0042 \\
(1.31)\end{array}$ & $\begin{array}{l}-.0013 \\
(0.58)\end{array}$ & $\begin{array}{l}-.0002 \\
(0.09)\end{array}$ & $\begin{array}{l}-.0037 \\
(1.52)\end{array}$ & $\begin{array}{l}-.0012 \\
(0.60)\end{array}$ \\
\hline Independence dummy & $\begin{array}{l}.0993 \\
(1.76)^{*}\end{array}$ & $\begin{array}{l}.0358 \\
(1.04)\end{array}$ & $\begin{array}{l}.1031 \\
(1.73)^{*}\end{array}$ & $\begin{array}{l}.1450 \\
(2.47)^{* *}\end{array}$ & $\begin{array}{l}.1004 \\
(2.61)^{* * *}\end{array}$ & $\begin{array}{l}.1355 \\
(2.40)^{* *}\end{array}$ \\
\hline Loan loss provisions ratio & $\begin{array}{l}.0157 \\
(2.85)^{* * *}\end{array}$ & $\begin{array}{l}.0149 \\
(2.78) * * *\end{array}$ & $\begin{array}{l}.0239 \\
(5.14)^{* * *}\end{array}$ & $\begin{array}{l}.0108 \\
(1.85)^{*}\end{array}$ & $\begin{array}{l}.0102 \\
(1.87)^{*}\end{array}$ & $\begin{array}{l}.0197 \\
(4.65)^{* * *}\end{array}$ \\
\hline Liquidity ratio & $\begin{array}{l}.0086 \\
(1.88)^{*}\end{array}$ & $\begin{array}{l}.0130 \\
(3.77) * * *\end{array}$ & $\begin{array}{l}.0100 \\
(2.45)^{* *}\end{array}$ & $\begin{array}{l}.0126 \\
(1.90)^{*}\end{array}$ & $\begin{array}{l}.0207 \\
(5.63) * * *\end{array}$ & $\begin{array}{l}.0136 \\
(2.17)^{* *}\end{array}$ \\
\hline GDP per capita & $\begin{array}{l}-.7124 \\
(0.45)\end{array}$ & $\begin{array}{l}-1.574 \\
(1.54)\end{array}$ & $\begin{array}{l}-1.672 \\
(1.20)\end{array}$ & $\begin{array}{l}-.7324 \\
(0.53)\end{array}$ & $\begin{array}{l}-1.563 \\
(1.42)\end{array}$ & $\begin{array}{l}-1.313 \\
(1.06)\end{array}$ \\
\hline Capital regulation index & $\begin{array}{l}-.1435 \\
(0.90)\end{array}$ & $\begin{array}{l}.2142 \\
(1.77)^{*}\end{array}$ & $\begin{array}{l}-.3648 \\
(3.74)^{* * *}\end{array}$ & $\begin{array}{l}-.1550 \\
(1.36)\end{array}$ & $\begin{array}{l}.1883 \\
(1.58)\end{array}$ & $\begin{array}{l}-.3001 \\
(3.54)^{* * *}\end{array}$ \\
\hline Supervisory power index & $\begin{array}{l}-.0378 \\
(0.36)\end{array}$ & $\begin{array}{l}.0874 \\
(0.24)\end{array}$ & $\begin{array}{l}-.0727 \\
(0.56)\end{array}$ & $\begin{array}{l}-.0730 \\
(0.82)\end{array}$ & $\begin{array}{l}-.0913 \\
(0.26)\end{array}$ & $\begin{array}{l}-.0582 \\
(0.53)\end{array}$ \\
\hline Disclosure-insurance index & $\begin{array}{l}.2018 \\
(0.56)\end{array}$ & $\begin{array}{l}.8282 \\
(3.41)^{* * *}\end{array}$ & $\begin{array}{l}.4485 \\
(1.25)\end{array}$ & $\begin{array}{l}.2895 \\
(1.03)\end{array}$ & $\begin{array}{l}.5024 \\
(2.29)^{* *}\end{array}$ & $\begin{array}{l}.3528 \\
(1.20)\end{array}$ \\
\hline Country dummies & Yes & Yes & Yes & Yes & Yes & Yes \\
\hline Year dummies & Yes & Yes & Yes & Yes & Yes & Yes \\
\hline Number of clusters & 40 & 28 & 31 & 40 & 28 & 31 \\
\hline Observations & 2048 & 1762 & 1966 & 2048 & 1761 & 1965 \\
\hline
\end{tabular}


Panel B: Sample I (4,442 banking firm-year observations over the period 2002-2008)

\begin{tabular}{|c|c|c|c|c|c|c|}
\hline \multirow{2}{*}{ Dependent variable: } & \multicolumn{3}{|c|}{ Standard deviation of return } & \multicolumn{3}{|c|}{ Earnings volatility } \\
\hline & High DI & High SP & High ED & High DI & High SP & High ED \\
\hline & $(1)$ & $(2)$ & (3) & (4) & $(5)$ & (6) \\
\hline $\mathrm{SND/TL}$ & $\begin{array}{l}-1.146 \\
(3.30)^{* * *}\end{array}$ & $\begin{array}{l}-1.398 \\
(2.34)^{* *}\end{array}$ & $\begin{array}{l}-.9060 \\
(3.92)^{* * *}\end{array}$ & $\begin{array}{l}-.9116 \\
(4.32)^{* * *}\end{array}$ & $\begin{array}{l}-1.013 \\
(4.06)^{* * *}\end{array}$ & $\begin{array}{l}-.8214 \\
(3.99)^{* * * *}\end{array}$ \\
\hline Loan growth & $\begin{array}{l}.0078 \\
(3.34)^{* * *}\end{array}$ & $\begin{array}{l}.0071 \\
(2.66) * * *\end{array}$ & $\begin{array}{l}.0067 \\
(3.67) * * *\end{array}$ & $\begin{array}{l}.0066 \\
(3.82) * * *\end{array}$ & $\begin{array}{l}.0058 \\
(2.77) * * *\end{array}$ & $\begin{array}{l}.0068 \\
(4.28) * * *\end{array}$ \\
\hline Size & $\begin{array}{l}.2731 \\
(2.43)^{* *}\end{array}$ & $\begin{array}{l}.4000 \\
(2.17)^{* *}\end{array}$ & $\begin{array}{l}.1746 \\
(1.83)^{*}\end{array}$ & $\begin{array}{l}.2086 \\
(2.39)^{* *}\end{array}$ & $\begin{array}{l}.2808 \\
(3.74)^{* * *}\end{array}$ & $\begin{array}{l}.1525 \\
(1.70)^{*}\end{array}$ \\
\hline Demand deposits ratio & $\begin{array}{l}.0005 \\
(0.23)\end{array}$ & $\begin{array}{l}.0006 \\
(0.19)\end{array}$ & $\begin{array}{l}.0008 \\
(0.35)\end{array}$ & $\begin{array}{l}.0005 \\
(0.26)\end{array}$ & $\begin{array}{l}.0003 \\
(0.14)\end{array}$ & $\begin{array}{l}.0013 \\
(0.63)\end{array}$ \\
\hline Independence dummy & $\begin{array}{l}.0330 \\
(0.27)\end{array}$ & $\begin{array}{l}-.0524 \\
(0.98)\end{array}$ & $\begin{array}{l}-.0518 \\
(1.01)\end{array}$ & $\begin{array}{l}.0658 \\
(0.70)\end{array}$ & $\begin{array}{l}.00433 \\
(0.12)\end{array}$ & $\begin{array}{l}-.0068 \\
(0.13)\end{array}$ \\
\hline Loan loss provisions ratio & $\begin{array}{l}.0163 \\
(7.00)^{* * *}\end{array}$ & $\begin{array}{l}.0158 \\
(7.36)^{* * *}\end{array}$ & $\begin{array}{l}.0157 \\
(4.11)^{* * *}\end{array}$ & $\begin{array}{l}.0113 \\
(3.84)^{* * *}\end{array}$ & $\begin{array}{l}.0099 \\
(3.28)^{* * *}\end{array}$ & $\begin{array}{l}.0128 \\
(3.59)^{* * *}\end{array}$ \\
\hline Liquidity ratio & $\begin{array}{l}.0005 \\
(0.18)\end{array}$ & $\begin{array}{l}.0028 \\
(0.75)\end{array}$ & $\begin{array}{l}-.0017 \\
(0.43)\end{array}$ & $\begin{array}{l}.0029 \\
(0.68)\end{array}$ & $\begin{array}{l}.0070 \\
(1.39)\end{array}$ & $\begin{array}{l}.0024 \\
(0.46)\end{array}$ \\
\hline GDP per capita & $\begin{array}{l}-2.008 \\
(2.59)^{* * * *}\end{array}$ & $\begin{array}{l}-2.803 \\
(2.81)^{* * * *}\end{array}$ & $\begin{array}{l}-1.080 \\
(1.47)\end{array}$ & $\begin{array}{l}-1.395 \\
(2.53)^{* *}\end{array}$ & $\begin{array}{l}-1.907 \\
(3.20)^{* * *}\end{array}$ & $\begin{array}{l}-.6327 \\
(0.99)\end{array}$ \\
\hline Capital regulation index & $\begin{array}{l}.0250 \\
(0.49)\end{array}$ & $\begin{array}{l}.0584 \\
(1.31)\end{array}$ & $\begin{array}{l}-.0833 \\
(0.85)\end{array}$ & $\begin{array}{l}-.0323 \\
(1.01)\end{array}$ & $\begin{array}{l}-.0143 \\
(0.42)\end{array}$ & $\begin{array}{l}-.0762 \\
(0.94)\end{array}$ \\
\hline Supervisory power index & $\begin{array}{l}-.0868 \\
(0.96)\end{array}$ & $\begin{array}{l}.0242 \\
(0.17)\end{array}$ & $\begin{array}{l}.0726 \\
(1.28)\end{array}$ & $\begin{array}{l}-.0814 \\
(1.35)\end{array}$ & $\begin{array}{l}-.0494 \\
(0.45)\end{array}$ & $\begin{array}{l}.0635 \\
(1.16)\end{array}$ \\
\hline Disclosure-insurance index & $\begin{array}{l}.0313 \\
(0.05)\end{array}$ & $\begin{array}{l}.5542 \\
(2.03)^{* *}\end{array}$ & $\begin{array}{l}.0151 \\
(0.08)\end{array}$ & $\begin{array}{l}.0717 \\
(0.15)\end{array}$ & $\begin{array}{l}.3766 \\
(2.13)^{* *}\end{array}$ & $\begin{array}{l}-.0127 \\
(0.07)\end{array}$ \\
\hline Country dummies & Yes & Yes & Yes & Yes & Yes & Yes \\
\hline Year dummies & Yes & Yes & Yes & Yes & Yes & Yes \\
\hline Number of clusters & 55 & 46 & 50 & 55 & 46 & 50 \\
\hline Observations & 3879 & 3535 & 3690 & 3879 & 3533 & 3689 \\
\hline Test of endogeneity (p-value) & 0.0000 & 0.0000 & 0.0000 & 0.0000 & 0.0000 & 0.0000 \\
\hline Partial R2 of instruments & 0.0281 & 0.0192 & 0.0376 & 0.0281 & 0.0197 & 0.0375 \\
\hline F-test of instruments (p-value) & 0.0000 & 0.0007 & 0.0000 & 0.0000 & 0.0007 & 0.0000 \\
\hline Hansen J test (p-value) & 0.3737 & 0.2834 & 0.2799 & 0.3785 & 0.3646 & 0.2579 \\
\hline
\end{tabular}




\section{Table XI: The Impact of Changes in Subordinated Debt on Changes in Bank Risk Taking}

Dependent variable is the change in outcome from t-1 to t, with outcome being z-score in Columns (1)-(3), standard deviation of return in columns (4)-(6), and earnings volatility in Columns (7)-(9). The change in SND/RWA is from t-1 to t. Control variables are measured at t-1. All regressions are estimated using 2SLS, where Columns (1), (4), and (7) report the results for the High subsample on Disclosure-insurance index (High DI); Columns (2), (5), and (8) - results for the High subsample on Supervisory power index (High SP); and Columns (3), (6), and (9) - results for the High subsample on Economic development (High ED). The IVs for the change in SND/RWA are the change in average SND ratio of other banks in the same country, year, and size group, the change in lagged equity-to-assets ratio, and the change in average tax rate. See Table I for variable definition. Also included are the p-value of the regression-based test of endogeneity, the partial R 2 of excluded instruments, the p-value of the F-test of excluded instruments, and the p-value of the Hansen J test of overidentification. Standard errors are clustered at the country level. z- statistics are reported in parentheses. $* * *$, and $* * *$ indicate significance at the $10 \%, 5 \%$, and $1 \%$ levels, respectively.

\begin{tabular}{|c|c|c|c|c|c|c|c|c|c|}
\hline \multirow[t]{2}{*}{ Dependent variable: } & \multicolumn{3}{|c|}{ Change in z-score } & \multicolumn{3}{|c|}{ Change in standard deviation of return } & \multicolumn{3}{|c|}{ Change in earnings volatility } \\
\hline & High DI & High SP & High ED & High DI & High SP & High ED & High DI & High SP & High ED \\
\hline & $(1)$ & $(2)$ & (3) & $(4)$ & $(5)$ & (6) & (7) & $(8)$ & (9) \\
\hline Change in SND/RWA & $\begin{array}{l}.3641 \\
(1.64)\end{array}$ & $\begin{array}{l}-.3861 \\
(0.82)\end{array}$ & $\begin{array}{l}.6556 \\
(6.63) * * *\end{array}$ & $\begin{array}{l}-.8902 \\
(2.89) * * *\end{array}$ & $\begin{array}{l}.0452 \\
(0.53)\end{array}$ & $\begin{array}{l}-1.256 \\
(2.90)^{* * *}\end{array}$ & $\begin{array}{l}-.8215 \\
(2.81)^{* * * *}\end{array}$ & $\begin{array}{l}-.1036 \\
(1.03)\end{array}$ & $\begin{array}{l}-1.125 \\
(3.07)^{* * * *}\end{array}$ \\
\hline Loan growth & $\begin{array}{l}.0028 \\
(4.80)^{* * * *}\end{array}$ & $\begin{array}{l}.0025 \\
(6.57)^{* * * *}\end{array}$ & $\begin{array}{l}.0025 \\
(3.77) * * *\end{array}$ & $\begin{array}{l}-.0030 \\
(2.71)^{* * * *}\end{array}$ & $\begin{array}{l}-.0039 \\
(12.59)^{* * *}\end{array}$ & $\begin{array}{l}-.0032 \\
(3.77) * * *\end{array}$ & $\begin{array}{l}-.0030 \\
(2.28) * *\end{array}$ & $\begin{array}{l}-.0039 \\
(7.64)^{* * *}\end{array}$ & $\begin{array}{l}-.0034 \\
(3.91)^{* * * *}\end{array}$ \\
\hline Size & $\begin{array}{l}-.0637 \\
(18.64)^{* * *}\end{array}$ & $\begin{array}{l}-.0591 \\
(14.18)^{* * * *}\end{array}$ & $\begin{array}{l}-.0686 \\
(15.58)^{* * *}\end{array}$ & $\begin{array}{l}.0524 \\
(6.65)^{* * *}\end{array}$ & $\begin{array}{l}.0493 \\
(40.67)^{* * *}\end{array}$ & $\begin{array}{l}.0523 \\
(4.10)^{* * *}\end{array}$ & $\begin{array}{l}.0493 \\
(5.99) * * *\end{array}$ & $\begin{array}{l}.0485 \\
(31.72) * * *\end{array}$ & $\begin{array}{l}.0487 \\
(3.95)^{* * * *}\end{array}$ \\
\hline Demand deposits ratio & $\begin{array}{l}.0027 \\
(3.81)^{* * *}\end{array}$ & $\begin{array}{l}.0029 \\
(3.61)^{* * * *}\end{array}$ & $\begin{array}{l}.0021 \\
(1.82)^{*}\end{array}$ & $\begin{array}{l}-.0017 \\
(2.01)^{* *}\end{array}$ & $\begin{array}{l}-.0012 \\
(2.25)^{* *}\end{array}$ & $\begin{array}{l}-.0008 \\
(0.93)\end{array}$ & $\begin{array}{l}-.0016 \\
(2.16)^{* *}\end{array}$ & $\begin{array}{l}-.0013 \\
(3.98)^{* * *}\end{array}$ & $\begin{array}{l}-.0006 \\
(0.88)\end{array}$ \\
\hline Independence dummy & $\begin{array}{l}-.0480 \\
(2.32)^{* *}\end{array}$ & $\begin{array}{l}-.0508 \\
(2.15)^{* *}\end{array}$ & $\begin{array}{l}-.0392 \\
(2.44)^{* * *}\end{array}$ & $\begin{array}{l}.0285 \\
(1.00)\end{array}$ & $\begin{array}{l}.0134 \\
(0.77)\end{array}$ & $\begin{array}{l}.0055 \\
(0.23)\end{array}$ & $\begin{array}{l}.0387 \\
(1.95)^{*}\end{array}$ & $\begin{array}{l}.0258 \\
(3.90)^{* * * *}\end{array}$ & $\begin{array}{l}.0148 \\
(0.56)\end{array}$ \\
\hline Loan loss provisions ratio & $\begin{array}{l}.0007 \\
(0.33)\end{array}$ & $\begin{array}{l}.0024 \\
(1.59)\end{array}$ & $\begin{array}{l}.0028 \\
(1.54)\end{array}$ & $\begin{array}{l}.0014 \\
(0.52)\end{array}$ & $\begin{array}{l}.0012 \\
(1.88)^{*}\end{array}$ & $\begin{array}{l}-.0013 \\
(0.56)\end{array}$ & $\begin{array}{l}.0010 \\
(0.39)\end{array}$ & $\begin{array}{l}.0011 \\
(2.43)^{* *}\end{array}$ & $\begin{array}{l}-.0012 \\
(0.71)\end{array}$ \\
\hline Liquidity ratio & $\begin{array}{l}.0044 \\
(2.68)^{* * *}\end{array}$ & $\begin{array}{l}.0057 \\
(9.95)^{* * *}\end{array}$ & $\begin{array}{l}.0035 \\
(1.85)^{*}\end{array}$ & $\begin{array}{l}-.0027 \\
(1.94)^{*}\end{array}$ & $\begin{array}{l}-.0039 \\
(6.43)^{* * *}\end{array}$ & $\begin{array}{l}-.0019 \\
(1.10)\end{array}$ & $\begin{array}{l}-.0017 \\
(1.35)\end{array}$ & $\begin{array}{l}-.0024 \\
(3.25)^{* * * *}\end{array}$ & $\begin{array}{l}-.0013 \\
(0.83)\end{array}$ \\
\hline GDP per capita & $\begin{array}{l}1.412 \\
(2.00)^{* *}\end{array}$ & $\begin{array}{l}.2261 \\
(0.46)\end{array}$ & $\begin{array}{l}2.094 \\
(3.31)^{* * *}\end{array}$ & $\begin{array}{l}-1.541 \\
(1.63)\end{array}$ & $\begin{array}{l}-.1276 \\
(0.50)\end{array}$ & $\begin{array}{l}-.7031 \\
(0.81)\end{array}$ & $\begin{array}{l}-1.504 \\
(1.92)^{*}\end{array}$ & $\begin{array}{l}-.5761 \\
(2.52) * *\end{array}$ & $\begin{array}{l}-.2990 \\
(0.35)\end{array}$ \\
\hline Capital regulation index & $\begin{array}{l}.1572 \\
(2.25) * *\end{array}$ & $\begin{array}{l}.1329 \\
(1.23)\end{array}$ & $\begin{array}{l}.1402 \\
(1.48)\end{array}$ & $\begin{array}{l}-.1899 \\
(4.13)^{* * *}\end{array}$ & $\begin{array}{l}.0618 \\
(2.39)^{* * *}\end{array}$ & $\begin{array}{l}-.2768 \\
(2.83)^{* * * *}\end{array}$ & $\begin{array}{l}-.1152 \\
(2.98)^{* * * *}\end{array}$ & $\begin{array}{l}.0568 \\
(2.21)^{* * *}\end{array}$ & $\begin{array}{l}-.1736 \\
(1.92)^{*}\end{array}$ \\
\hline Supervisory power index & $\begin{array}{l}-.0088 \\
(0.17)\end{array}$ & $\begin{array}{l}-.1149 \\
(0.77)\end{array}$ & $\begin{array}{l}-.1183 \\
(2.87) * * *\end{array}$ & $\begin{array}{l}.0342 \\
(0.98)\end{array}$ & $\begin{array}{l}.1313 \\
(1.99)^{* *}\end{array}$ & $\begin{array}{l}.0373 \\
(0.72)\end{array}$ & $\begin{array}{l}.0619 \\
(1.86)^{*}\end{array}$ & $\begin{array}{l}-.1246 \\
(1.66)^{*}\end{array}$ & $\begin{array}{l}.0395 \\
(0.80)\end{array}$ \\
\hline Disclosure-insurance index & $\begin{array}{l}.0432 \\
(0.27)\end{array}$ & $\begin{array}{l}-.1556 \\
(1.36)\end{array}$ & $\begin{array}{l}.2509 \\
(3.18)^{* * * *}\end{array}$ & $\begin{array}{l}-.0580 \\
(0.59)\end{array}$ & $\begin{array}{l}.2331 \\
(3.58)^{* * * *}\end{array}$ & $\begin{array}{l}-.1447 \\
(0.94)\end{array}$ & $\begin{array}{l}-.0305 \\
(0.42)\end{array}$ & $\begin{array}{l}-.0656 \\
(1.24)\end{array}$ & $\begin{array}{l}-.1584 \\
(1.03)\end{array}$ \\
\hline Country dummies & Yes & Yes & Yes & Yes & Yes & Yes & Yes & Yes & Yes \\
\hline Year dummies & Yes & Yes & Yes & Yes & Yes & Yes & Yes & Yes & Yes \\
\hline Number of clusters & 31 & 24 & 24 & 31 & 24 & 24 & 31 & 24 & 24 \\
\hline Observations & 1793 & 1604 & 1748 & 1793 & 1604 & 1748 & 1792 & 1603 & 1747 \\
\hline Test of endogeneity (p-value) & 0.0823 & 0.3361 & 0.0000 & 0.0000 & 0.6545 & 0.0000 & 0.0000 & 0.2301 & 0.0000 \\
\hline Partial R2 of instruments & 0.0054 & 0.0167 & 0.0056 & 0.0054 & 0.0167 & 0.0056 & 0.0043 & 0.0156 & 0.0048 \\
\hline F-test of instruments (p-value) & 0.0050 & 0.0117 & 0.0010 & 0.0050 & 0.0117 & 0.0010 & 0.0032 & 0.0992 & 0.0015 \\
\hline Hansen J test (p-value) & 0.5096 & 0.5489 & 0.4180 & 0.5197 & 0.3143 & 0.5192 & 0.5244 & 0.5007 & 0.5433 \\
\hline
\end{tabular}




\section{Table XII: Other Uninsured Debt}

Panels A, B, and C report the results for High subsamples on Disclosure-insurance index, on Supervisory power index, and on Economic development, respectively. Dependent variable is z-score in Columns (1)-(5), standard deviation of return in Column (6), and earnings volatility in Column (7). Regressors are lagged by one year. All regressions are estimated using 2SLS. The IVs for SND/RWA are the average SND ratio of other banks in the same country, year, and size group, the lagged capital-to-assets ratio, and the average tax rate. In Columns (5)-(7), the IVs for uninsured debt are the lagged capital-to-assets ratio and the average tax rate. See Table I for variable definition. Also included are the p-value of the regression-based test of endogeneity, the partial R2 of excluded instruments in the first-stage estimation of SND/RWA, the p-value of the F-test of excluded instruments in the first-stage estimation of SND/RWA, and the p-value of the Hansen J test of overidentification. Standard errors are clustered at the country level. zstatistics are reported in parentheses. $*, * *$, and $* * *$ indicate significance at the $10 \%, 5 \%$, and $1 \%$ levels, respectively.

\section{Panel A: High subsample on Disclosure-insurance index}

\begin{tabular}{|c|c|c|c|c|c|c|c|}
\hline \multirow[t]{2}{*}{ Dependent variable: } & \multicolumn{5}{|c|}{ Z-score } & \multirow{2}{*}{$\begin{array}{l}\text { Std. dev. of return } \\
(6)\end{array}$} & \multirow{2}{*}{$\begin{array}{l}\text { Earnings volatility } \\
(7)\end{array}$} \\
\hline & $(1)$ & $(2)$ & (3) & (4) & $(5)$ & & \\
\hline SND/RWA & $\begin{array}{l}.2587 \\
(2.65)^{* * *}\end{array}$ & $\begin{array}{l}.2646 \\
(2.71)^{* * *}\end{array}$ & $\begin{array}{l}.2620 \\
(2.68)^{* * *}\end{array}$ & $\begin{array}{l}.2617 \\
(2.68)^{* * *}\end{array}$ & $\begin{array}{l}.6669 \\
(4.94)^{* * *}\end{array}$ & $\begin{array}{l}-1.430 \\
(6.17)^{* * *}\end{array}$ & $\begin{array}{l}-1.195 \\
(6.71)^{* * *}\end{array}$ \\
\hline ST uninsured debt & $\begin{array}{l}.0005 \\
(0.21)\end{array}$ & & $\begin{array}{l}.0008 \\
(0.32)\end{array}$ & & & & \\
\hline Other LT uninsured debt & & $\begin{array}{l}-.0031 \\
(1.33)\end{array}$ & $\begin{array}{l}-.0032 \\
(1.35)\end{array}$ & & & & \\
\hline Other uninsured debt & & & & $\begin{array}{l}-.0012 \\
(0.71)\end{array}$ & $\begin{array}{l}-.1064 \\
(3.96)^{* * *}\end{array}$ & $\begin{array}{l}.0860 \\
(2.15)^{* *}\end{array}$ & $\begin{array}{l}.0593 \\
(1.97)^{* *}\end{array}$ \\
\hline Loan growth & $\begin{array}{l}-.0130 \\
(7.61)^{* * *}\end{array}$ & $\begin{array}{l}-.0131 \\
(7.56)^{* * *}\end{array}$ & $\begin{array}{l}-.0131 \\
(7.53) * * *\end{array}$ & $\begin{array}{l}-.0130 \\
(7.60)^{* * *}\end{array}$ & $\begin{array}{l}-.0186 \\
(7.94)^{* * *}\end{array}$ & $\begin{array}{l}.0185 \\
(6.07)^{* * *}\end{array}$ & $\begin{array}{l}.0168 \\
(6.60)^{* * *}\end{array}$ \\
\hline Size & $\begin{array}{l}-.0348 \\
(1.15)\end{array}$ & $\begin{array}{l}-.0318 \\
(1.06)\end{array}$ & $\begin{array}{l}-.0323 \\
(1.05)\end{array}$ & $\begin{array}{l}-.0310 \\
(1.04)\end{array}$ & $\begin{array}{l}.1579 \\
(2.35)^{* *}\end{array}$ & $\begin{array}{l}.2019 \\
(0.97)\end{array}$ & $\begin{array}{l}.1980 \\
(1.21)\end{array}$ \\
\hline Demand deposits ratio & $\begin{array}{l}.0023 \\
(0.67)\end{array}$ & $\begin{array}{l}.0021 \\
(0.62)\end{array}$ & $\begin{array}{l}.0020 \\
(0.60)\end{array}$ & $\begin{array}{l}.0022 \\
(0.67)\end{array}$ & $\begin{array}{l}-.0012 \\
(0.24)\end{array}$ & $\begin{array}{l}.0016 \\
(0.28)\end{array}$ & $\begin{array}{l}.0007 \\
(0.15)\end{array}$ \\
\hline Independence dummy & $\begin{array}{l}-.0515 \\
(1.15)\end{array}$ & $\begin{array}{l}-.0511 \\
(1.13)\end{array}$ & $\begin{array}{l}-.0513 \\
(1.15)\end{array}$ & $\begin{array}{l}-.0492 \\
(1.10)\end{array}$ & $\begin{array}{l}.0153 \\
(0.20)\end{array}$ & $\begin{array}{l}.2536 \\
(2.33)^{* * *}\end{array}$ & $\begin{array}{l}.2964 \\
(3.80)^{* * *}\end{array}$ \\
\hline Loan loss provisions ratio & $\begin{array}{l}-.0203 \\
(3.07)^{* * *}\end{array}$ & $\begin{array}{l}-.0203 \\
(3.04)^{* * *}\end{array}$ & $\begin{array}{l}-.0203 \\
(3.04)^{* * *}\end{array}$ & $\begin{array}{l}-.0203 \\
(3.05)^{* * *}\end{array}$ & $\begin{array}{l}-.0220 \\
(2.12)^{* *}\end{array}$ & $\begin{array}{l}.0167 \\
(1.78)^{*}\end{array}$ & $\begin{array}{l}.0112 \\
(1.28)\end{array}$ \\
\hline Liquidity ratio & $\begin{array}{l}-.0033 \\
(1.27)\end{array}$ & $\begin{array}{l}-.0033 \\
(1.27)\end{array}$ & $\begin{array}{l}-.0034 \\
(1.28)\end{array}$ & $\begin{array}{l}-.0034 \\
(1.26)\end{array}$ & $\begin{array}{l}-.0042 \\
(0.79)\end{array}$ & $\begin{array}{l}.0003 \\
(0.08)\end{array}$ & $\begin{array}{l}.0053 \\
(1.23)\end{array}$ \\
\hline GDP per capita & $\begin{array}{l}.5953 \\
(0.67)\end{array}$ & $\begin{array}{l}.6335 \\
(0.71)\end{array}$ & $\begin{array}{l}.6385 \\
(0.71)\end{array}$ & $\begin{array}{l}.6020 \\
(0.68)\end{array}$ & $\begin{array}{l}1.440 \\
(0.77)\end{array}$ & $\begin{array}{l}-.9855 \\
(0.41)\end{array}$ & $\begin{array}{l}-.8145 \\
(0.43)\end{array}$ \\
\hline Capital regulation index & $\begin{array}{l}.0903 \\
(1.05)\end{array}$ & $\begin{array}{l}.0904 \\
(1.06)\end{array}$ & $\begin{array}{l}.0894 \\
(1.05)\end{array}$ & $\begin{array}{l}.0912 \\
(1.07)\end{array}$ & $\begin{array}{l}.1786 \\
(1.68)^{*}\end{array}$ & $\begin{array}{l}-.2488 \\
(1.29)\end{array}$ & $\begin{array}{l}-.2357 \\
(1.66)^{*}\end{array}$ \\
\hline Supervisory power index & $\begin{array}{l}-.0178 \\
(0.33)\end{array}$ & $\begin{array}{l}-.0182 \\
(0.33)\end{array}$ & $\begin{array}{l}-.0186 \\
(0.34)\end{array}$ & $\begin{array}{l}-.0175 \\
(0.33)\end{array}$ & $\begin{array}{l}.0107 \\
(0.10)\end{array}$ & $\begin{array}{l}-.0446 \\
(0.29)\end{array}$ & $\begin{array}{l}-.0750 \\
(0.59)\end{array}$ \\
\hline Disclosure-insurance index & $\begin{array}{l}-.2336 \\
(0.93)\end{array}$ & $\begin{array}{l}-.2322 \\
(0.91)\end{array}$ & $\begin{array}{l}-.2318 \\
(0.91)\end{array}$ & $\begin{array}{l}-.2322 \\
(0.92)\end{array}$ & $\begin{array}{l}-.2042 \\
(0.39)\end{array}$ & $\begin{array}{l}.3947 \\
(0.59)\end{array}$ & $\begin{array}{l}.4546 \\
(0.93)\end{array}$ \\
\hline Country dummies & Yes & Yes & Yes & Yes & Yes & Yes & Yes \\
\hline
\end{tabular}




\begin{tabular}{lllllll} 
Year dummies & Yes & Yes & Yes & Yes & Yes & Yes \\
\hline Number of clusters & 40 & 40 & 40 & 40 & 40 & 40 \\
Observations & 1562 & 1562 & 1562 & 1562 & 1562 & 1562 \\
Test of endogeneity (p-value) & 0.0001 & 0.0000 & 0.0000 & 0.0000 & 0.0000 & 0.0000 \\
Partial R2 of instruments & 0.0624 & 0.0623 & 0.0624 & 0.0624 & 0.0624 & 0.0624 \\
F-test of instruments (p-value) & 0.0000 & 0.0000 & 0.0000 & 0.0000 & 0.0000 & 0.0000 \\
Hansen J test (p-value) & 0.4220 & 0.4054 & 0.4059 & 0.4189 & 0.9997 & 0.0000 \\
& & & & & 0.0000 \\
\hline
\end{tabular}

\section{Panel B: High subsample on Supervisory power index}

\begin{tabular}{|c|c|c|c|c|c|c|c|}
\hline \multirow[t]{2}{*}{ Dependent variable: } & \multicolumn{5}{|c|}{ Z-score } & \multirow{2}{*}{$\begin{array}{l}\text { Std. dev. of return } \\
(6) \\
\end{array}$} & \multirow{2}{*}{$\begin{array}{l}\text { Earnings volatility } \\
(7) \\
\end{array}$} \\
\hline & $(1)$ & $(2)$ & (3) & $(4)$ & $(5)$ & & \\
\hline SND/RWA & $\begin{array}{l}.3098 \\
(10.18) * * *\end{array}$ & $\begin{array}{l}.3232 \\
(10.25)^{* * *}\end{array}$ & $\begin{array}{l}.3164 \\
(10.30)^{* * *}\end{array}$ & $\begin{array}{l}.3140 \\
(10.48)^{* * *}\end{array}$ & $\begin{array}{l}.6124 \\
(13.00) * * *\end{array}$ & $\begin{array}{l}-1.496 \\
(18.93)^{* * *}\end{array}$ & $\begin{array}{l}-1.216 \\
(18.07)^{* * *}\end{array}$ \\
\hline ST uninsured debt & $\begin{array}{l}.0003 \\
(0.26)\end{array}$ & & $\begin{array}{l}.0008 \\
(0.59)\end{array}$ & & & & \\
\hline Other LT uninsured debt & & $\begin{array}{l}-.0039 \\
(2.09)^{* *}\end{array}$ & $\begin{array}{l}-.0039 \\
(2.12)^{* *}\end{array}$ & & & & \\
\hline Other uninsured debt & & & & $\begin{array}{l}-.0016 \\
(1.45)\end{array}$ & $\begin{array}{l}-.0917 \\
(9.76)^{* * *}\end{array}$ & $\begin{array}{l}.0695 \\
(3.23)^{* * *}\end{array}$ & $\begin{array}{l}.0469 \\
(2.84)^{* * *}\end{array}$ \\
\hline Loan growth & $\begin{array}{l}-.0119 \\
(5.28)^{* * *}\end{array}$ & $\begin{array}{l}-.0121 \\
(5.31)^{* * *}\end{array}$ & $\begin{array}{l}-.0121 \\
(5.33)^{* * *}\end{array}$ & $\begin{array}{l}-.0120 \\
(5.32)^{* * *}\end{array}$ & $\begin{array}{l}-.0162 \\
(5.65)^{* * *}\end{array}$ & $\begin{array}{l}.0170 \\
(5.26)^{* * *}\end{array}$ & $\begin{array}{l}.0154 \\
(5.71)^{* * *}\end{array}$ \\
\hline Size & $\begin{array}{l}-.0499 \\
(3.23)^{* * *}\end{array}$ & $\begin{array}{l}-.0504 \\
(3.37)^{* * *}\end{array}$ & $\begin{array}{l}-.0492 \\
(3.09) * * *\end{array}$ & $\begin{array}{l}-.0455 \\
(2.94)^{* * *}\end{array}$ & $\begin{array}{l}.1324 \\
(4.58)^{* * *}\end{array}$ & $\begin{array}{l}.3361 \\
(3.79)^{* * *}\end{array}$ & $\begin{array}{l}.2973 \\
(4.64)^{* * *}\end{array}$ \\
\hline Demand deposits ratio & $\begin{array}{l}.0077 \\
(2.95) * * *\end{array}$ & $\begin{array}{l}.0072 \\
(2.69) * * *\end{array}$ & $\begin{array}{l}.0072 \\
(2.68) * * *\end{array}$ & $\begin{array}{l}.0074 \\
(2.77)^{* * * *}\end{array}$ & $\begin{array}{l}-.0060 \\
(1.38)\end{array}$ & $\begin{array}{l}.0032 \\
(0.59)\end{array}$ & $\begin{array}{l}.0009 \\
(0.21)\end{array}$ \\
\hline Independence dummy & $\begin{array}{l}.0013 \\
(0.02)\end{array}$ & $\begin{array}{l}-.0009 \\
(0.01)\end{array}$ & $\begin{array}{l}.0009 \\
(0.01)\end{array}$ & $\begin{array}{l}.0026 \\
(0.04)\end{array}$ & $\begin{array}{l}.0319 \\
(0.44)\end{array}$ & $\begin{array}{l}.2670 \\
(4.38)^{* * * *}\end{array}$ & $\begin{array}{l}.3013 \\
(7.92)^{* * *}\end{array}$ \\
\hline Loan loss provisions ratio & $\begin{array}{l}-.0197 \\
(2.64)^{* * *}\end{array}$ & $\begin{array}{l}-.0198 \\
(2.60)^{* * *}\end{array}$ & $\begin{array}{l}-.0198 \\
(2.61)^{* * *}\end{array}$ & $\begin{array}{l}-.0197 \\
(2.62)^{* * *}\end{array}$ & $\begin{array}{l}-.0213 \\
(1.92)^{*}\end{array}$ & $\begin{array}{l}.0159 \\
(1.71)^{*}\end{array}$ & $\begin{array}{l}.0108 \\
(1.27)\end{array}$ \\
\hline Liquidity ratio & $\begin{array}{l}-.0064 \\
(4.53)^{* * *}\end{array}$ & $\begin{array}{l}-.0064 \\
(4.76)^{* * *}\end{array}$ & $\begin{array}{l}-.0064 \\
(4.76)^{* * *}\end{array}$ & $\begin{array}{l}-.0065 \\
(4.59)^{* * *}\end{array}$ & $\begin{array}{l}-.0100 \\
(3.84)^{* * *}\end{array}$ & $\begin{array}{l}.0010 \\
(0.26)\end{array}$ & $\begin{array}{l}.0104 \\
(4.25)^{* * *}\end{array}$ \\
\hline GDP per capita & $\begin{array}{l}.9332 \\
(1.77)^{*}\end{array}$ & $\begin{array}{l}.9695 \\
(1.83)^{*}\end{array}$ & $\begin{array}{l}.9656 \\
(1.84)^{*}\end{array}$ & $\begin{array}{l}.9401 \\
(1.78)^{*}\end{array}$ & $\begin{array}{l}1.458 \\
(1.84)^{*}\end{array}$ & $\begin{array}{l}-1.937 \\
(1.78)^{*}\end{array}$ & $\begin{array}{l}-1.819 \\
(1.60)\end{array}$ \\
\hline Capital regulation index & $\begin{array}{l}-.1287 \\
(1.90)^{*}\end{array}$ & $\begin{array}{l}-.1310 \\
(1.90)^{*}\end{array}$ & $\begin{array}{l}-.1304 \\
(1.90)^{*}\end{array}$ & $\begin{array}{l}-.1288 \\
(1.87)^{*}\end{array}$ & $\begin{array}{l}-.1518 \\
(1.20)\end{array}$ & $\begin{array}{l}.3493 \\
(2.59)^{* * *}\end{array}$ & $\begin{array}{l}.2795 \\
(2.26)^{* *}\end{array}$ \\
\hline Supervisory power index & $\begin{array}{l}.0786 \\
(0.69)\end{array}$ & $\begin{array}{l}.0800 \\
(0.68)\end{array}$ & $\begin{array}{l}.0784 \\
(0.67)\end{array}$ & $\begin{array}{l}.0807 \\
(0.70)\end{array}$ & $\begin{array}{l}.1861 \\
(0.66)\end{array}$ & $\begin{array}{l}-.0311 \\
(0.06)\end{array}$ & $\begin{array}{l}-.1898 \\
(0.40)\end{array}$ \\
\hline Disclosure-insurance index & $\begin{array}{l}-.2699 \\
(2.72)^{* * *}\end{array}$ & $\begin{array}{l}-.2702 \\
(2.68)^{* * * *}\end{array}$ & $\begin{array}{l}-.2673 \\
(2.65)^{* * *}\end{array}$ & $\begin{array}{l}-.2691 \\
(2.71)^{* * *}\end{array}$ & $\begin{array}{l}-.2576 \\
(1.38)\end{array}$ & $\begin{array}{l}.7976 \\
(2.11)^{* *}\end{array}$ & $\begin{array}{l}.4872 \\
(1.52)\end{array}$ \\
\hline Country dummies & Yes & Yes & Yes & Yes & Yes & Yes & Yes \\
\hline
\end{tabular}




\begin{tabular}{lllllll} 
Year dummies & Yes & Yes & Yes & Yes & Yes & Yes \\
\hline Number of clusters & 28 & 28 & 28 & 28 & 28 & 28 \\
Observations & 1277 & 1277 & 1277 & 1277 & 1277 & 1277 \\
Test of endogeneity (p-value) & 0.0000 & 0.0000 & 0.0000 & 0.0000 & 0.0000 & 0.0000 \\
Partial R2 of instruments & 0.0655 & 0.0638 & 0.0652 & 0.0648 & 0.0641 & 0.0641 \\
F-test of instruments (p-value) & 0.0000 & 0.0000 & 0.0000 & 0.0000 & 0.0000 & 0.0000 \\
Hansen J test (p-value) & 0.5837 & 0.5986 & 0.5975 & 0.5859 & 0.4679 & 0.0640 \\
& & & & & 0.6000 \\
\hline
\end{tabular}

\section{Panel C: High subsample on Economic development}

\begin{tabular}{|c|c|c|c|c|c|c|c|}
\hline \multirow[t]{2}{*}{ Dependent variable: } & \multicolumn{5}{|c|}{ Z-score } & \multirow{2}{*}{$\begin{array}{l}\text { Std. dev. of return } \\
(6) \\
\end{array}$} & \multirow{2}{*}{$\begin{array}{l}\text { Earnings volatility } \\
(7) \\
\end{array}$} \\
\hline & $(1)$ & $(2)$ & (3) & $(4)$ & $(5)$ & & \\
\hline SND/RWA & $\begin{array}{l}.3317 \\
(3.29)^{* * *}\end{array}$ & $\begin{array}{l}.3312 \\
(3.10)^{* * *}\end{array}$ & $\begin{array}{l}.3332 \\
(3.24)^{* * *}\end{array}$ & $\begin{array}{l}.3332 \\
(3.22)^{* * *}\end{array}$ & $\begin{array}{l}.5974 \\
(5.31)^{* * *}\end{array}$ & $\begin{array}{l}-1.333 \\
(5.12)^{* * *}\end{array}$ & $\begin{array}{l}-1.152 \\
(6.42)^{* * *}\end{array}$ \\
\hline ST uninsured debt & $\begin{array}{l}-.0024 \\
(0.61)\end{array}$ & & $\begin{array}{l}-.0021 \\
(0.52)\end{array}$ & & & & \\
\hline Other LT uninsured debt & & $\begin{array}{l}-.0029 \\
(1.03)\end{array}$ & $\begin{array}{l}-.0027 \\
(0.96)\end{array}$ & & & & \\
\hline Other uninsured debt & & & & $\begin{array}{l}-.0024 \\
(1.15)\end{array}$ & $\begin{array}{l}-.0814 \\
(9.34)^{* * *}\end{array}$ & $\begin{array}{l}.0424 \\
(3.01)^{* * *}\end{array}$ & $\begin{array}{l}.0275 \\
(2.57)^{* * *}\end{array}$ \\
\hline Loan growth & $\begin{array}{l}-.0134 \\
(12.50)^{* * *}\end{array}$ & $\begin{array}{l}-.0135 \\
(12.10)^{* * *}\end{array}$ & $\begin{array}{l}-.0135 \\
(12.38)^{* * *}\end{array}$ & $\begin{array}{l}-.0135 \\
(12.71)^{* * *}\end{array}$ & $\begin{array}{l}-.0178 \\
(11.81)^{* * *}\end{array}$ & $\begin{array}{l}.01664 \\
(6.27)^{* * *}\end{array}$ & $\begin{array}{l}.0154 \\
(7.12)^{* * *}\end{array}$ \\
\hline Size & $\begin{array}{l}-.0600 \\
(1.98)^{* *}\end{array}$ & $\begin{array}{l}-.0605 \\
(2.26)^{* *}\end{array}$ & $\begin{array}{l}-.0572 \\
(1.94)^{*}\end{array}$ & $\begin{array}{l}-.0570 \\
(2.03)^{* *}\end{array}$ & $\begin{array}{l}.1228 \\
(3.18)^{* * * *}\end{array}$ & $\begin{array}{l}.2955 \\
(2.17)^{* *}\end{array}$ & $\begin{array}{l}.2772 \\
(2.57)^{* *}\end{array}$ \\
\hline Demand deposits ratio & $\begin{array}{l}.0015 \\
(0.33)\end{array}$ & $\begin{array}{l}.0011 \\
(0.24)\end{array}$ & $\begin{array}{l}.0012 \\
(0.28)\end{array}$ & $\begin{array}{l}.0013 \\
(0.27)\end{array}$ & $\begin{array}{l}-.0009 \\
(0.27)\end{array}$ & $\begin{array}{l}-.0016 \\
(0.49)\end{array}$ & $\begin{array}{l}-.0017 \\
(0.67)\end{array}$ \\
\hline Independence dummy & $\begin{array}{l}-.0847 \\
(1.95)^{*}\end{array}$ & $\begin{array}{l}-.0867 \\
(1.98)^{* *}\end{array}$ & $\begin{array}{l}-.0840 \\
(1.94)^{*}\end{array}$ & $\begin{array}{l}-.0836 \\
(1.96)^{* *}\end{array}$ & $\begin{array}{l}.0034 \\
(0.06)\end{array}$ & $\begin{array}{l}.2918 \\
(4.71)^{* * *}\end{array}$ & $\begin{array}{l}.3178 \\
(6.09)^{* * *}\end{array}$ \\
\hline Loan loss provisions ratio & $\begin{array}{l}-.0293 \\
(2.96)^{* * *}\end{array}$ & $\begin{array}{l}-.0293 \\
(2.92)^{* * *}\end{array}$ & $\begin{array}{l}-.0293 \\
(2.93)^{* * *}\end{array}$ & $\begin{array}{l}-.0293 \\
(2.93) * * *\end{array}$ & $\begin{array}{l}-.0319 \\
(2.31)^{* *}\end{array}$ & $\begin{array}{l}.0274 \\
(2.67)^{* * *}\end{array}$ & $\begin{array}{l}.0228 \\
(2.56)^{* * *}\end{array}$ \\
\hline Liquidity ratio & $\begin{array}{l}-.0032 \\
(1.40)\end{array}$ & $\begin{array}{l}-.0032 \\
(1.41)\end{array}$ & $\begin{array}{l}-.0032 \\
(1.41)\end{array}$ & $\begin{array}{l}-.0032 \\
(1.41)\end{array}$ & $\begin{array}{l}-.0059 \\
(1.50)\end{array}$ & $\begin{array}{l}.0018 \\
(0.52)\end{array}$ & $\begin{array}{l}.0060 \\
(2.04)^{* *}\end{array}$ \\
\hline GDP per capita & $\begin{array}{l}.2067 \\
(0.34)\end{array}$ & $\begin{array}{l}.2182 \\
(0.36)\end{array}$ & $\begin{array}{l}.2198 \\
(0.36)\end{array}$ & $\begin{array}{l}.2186 \\
(0.36)\end{array}$ & $\begin{array}{l}.7890 \\
(0.75)\end{array}$ & $\begin{array}{l}-1.083 \\
(0.75)\end{array}$ & $\begin{array}{l}-.6780 \\
(0.55)\end{array}$ \\
\hline Capital regulation index & $\begin{array}{l}.1730 \\
(2.61)^{* * *}\end{array}$ & $\begin{array}{l}.1705 \\
(2.53)^{* *}\end{array}$ & $\begin{array}{l}.1726 \\
(2.65)^{* * *}\end{array}$ & $\begin{array}{l}.1729 \\
(2.59)^{* * *}\end{array}$ & $\begin{array}{l}.2942 \\
(3.37)^{* * * *}\end{array}$ & $\begin{array}{l}-.5309 \\
(3.62)^{* * *}\end{array}$ & $\begin{array}{l}-.4294 \\
(3.70)^{* * *}\end{array}$ \\
\hline Supervisory power index & $\begin{array}{l}-.1150 \\
(1.63)\end{array}$ & $\begin{array}{l}-.1144 \\
(1.61)\end{array}$ & $\begin{array}{l}-.1143 \\
(1.62)\end{array}$ & $\begin{array}{l}-.1143 \\
(1.62)\end{array}$ & $\begin{array}{l}-.0707 \\
(0.75)\end{array}$ & $\begin{array}{l}-.1036 \\
(0.73)\end{array}$ & $\begin{array}{l}-.0813 \\
(0.70)\end{array}$ \\
\hline Disclosure-insurance index & $\begin{array}{l}-.0658 \\
(0.40)\end{array}$ & $\begin{array}{l}-.0596 \\
(0.36)\end{array}$ & $\begin{array}{l}-.0633 \\
(0.38)\end{array}$ & $\begin{array}{l}-.0641 \\
(0.38)\end{array}$ & $\begin{array}{l}-.2006 \\
(0.79)\end{array}$ & $\begin{array}{l}.5565 \\
(1.49)\end{array}$ & $\begin{array}{l}.4354 \\
(1.47)\end{array}$ \\
\hline Country dummies & Yes & Yes & Yes & Yes & Yes & Yes & Yes \\
\hline Year dummies & Yes & Yes & Yes & Yes & Yes & Yes & Yes \\
\hline
\end{tabular}




\begin{tabular}{lllllll}
\hline Number of clusters & 31 & 31 & 31 & 31 & 31 & 31 \\
Observations & 1480 & 1480 & 1480 & 1480 & 1480 & 1480 \\
Test of endogeneity (p-value) & 0.0000 & 0.0000 & 0.0000 & 0.0000 & 0.0000 & 0.0000 \\
Partial R2 of instruments & 0.0604 & 0.0605 & 0.0604 & 0.0604 & 0.0605 & 0.0605 \\
F-test of instruments (p-value) & 0.0000 & 0.0000 & 0.0000 & 0.0000 & 0.0000 & 0.0000 \\
Hansen J test (p-value) & 0.4608 & 0.4301 & 0.4390 & 0.4485 & 0.0647 & 0.0003 \\
& & & & 0.9090 & 0.9623 \\
\hline
\end{tabular}




\section{Table XIII: Bank-level Corporate Governance}

The table reports the results for a subset of US banks that have bank-level corporate governance data available, and Columns (7) - (9) of Panel B report the results for the whole US sample. Dependent variable is z-score in Columns (1), (4) and Panel B - Column (7), standard deviation of return in Columns (2), (5) and Panel B - Column (8), and earnings volatility in Columns (3), (6) and Panel B - Column (9). Regressors are lagged by one year. All regressions are estimated using 2SLS. The IVs for SND/RWA are the average SND ratio of other banks in the same country, year, and size group, the lagged capital-to-assets ratio, and the average tax rate. The governance index is expressed as a percentage, where satisfying all 52 corporate governance attributes earns a firm an index of $100 \%$. See Table I for variable definition. Also included are the p-value of the regression-based test of endogeneity, the partial R2 of excluded instruments in the first-stage estimation of SND/RWA, the p-value of the F-test of excluded instruments in the first-stage estimation of SND/RWA, and the p-value of the Hansen J test of overidentification. Standard errors are clustered at the firm level. $\mathrm{z}$ - statistics are reported in parentheses. *,**, and *** indicate significance at the $10 \%, 5 \%$, and $1 \%$ levels, respectively.

\section{Panel A: Without Firm fixed effects}

\begin{tabular}{|c|c|c|c|c|c|c|}
\hline \multirow[t]{2}{*}{ Dependent variable: } & Z-score & $\begin{array}{l}\text { Standard deviation } \\
\text { of return }\end{array}$ & Earnings volatility & Z-score & $\begin{array}{l}\text { Standard deviation } \\
\text { of return }\end{array}$ & Earnings volatility \\
\hline & $(1)$ & $(2)$ & (3) & $(4)$ & $(5)$ & $(6)$ \\
\hline SND/RWA & $\begin{array}{l}-.1736 \\
(1.69) *\end{array}$ & $\begin{array}{l}-.2343 \\
(2.37)^{* *}\end{array}$ & $\begin{array}{l}-.2585 \\
(2.21)^{* *}\end{array}$ & $\begin{array}{l}-.1841 \\
(1.81)^{*}\end{array}$ & $\begin{array}{l}-.2274 \\
(2.51)^{* *}\end{array}$ & $\begin{array}{l}-.2524 \\
(2.35)^{* *}\end{array}$ \\
\hline Loan growth & $\begin{array}{l}.0006 \\
(0.23)\end{array}$ & $\begin{array}{l}.0033 \\
(1.82)^{*}\end{array}$ & $\begin{array}{l}.0039 \\
(1.91)^{*}\end{array}$ & $\begin{array}{l}.0007 \\
(0.24)\end{array}$ & $\begin{array}{l}.0033 \\
(1.91)^{*}\end{array}$ & $\begin{array}{l}.0039 \\
(2.01)^{* *}\end{array}$ \\
\hline Size & $\begin{array}{l}.0621 \\
(1.41)\end{array}$ & $\begin{array}{l}.0717 \\
(1.76)^{*}\end{array}$ & $\begin{array}{l}.0797 \\
(1.68)^{*}\end{array}$ & $\begin{array}{l}.0766 \\
(1.74)^{*}\end{array}$ & $\begin{array}{l}.0567 \\
(1.61)\end{array}$ & $\begin{array}{l}.0642 \\
(1.59)\end{array}$ \\
\hline Demand deposits ratio & $\begin{array}{l}.0075 \\
(1.43)\end{array}$ & $\begin{array}{l}-.0017 \\
(0.58)\end{array}$ & $\begin{array}{l}-.0027 \\
(0.87)\end{array}$ & $\begin{array}{l}.0087 \\
(1.66) *\end{array}$ & $\begin{array}{l}-.0031 \\
(1.04)\end{array}$ & $\begin{array}{l}-.0042 \\
(1.27)\end{array}$ \\
\hline Independence dummy & $\begin{array}{l}-.1197 \\
(0.69)\end{array}$ & $\begin{array}{l}-.0292 \\
(0.24)\end{array}$ & $\begin{array}{l}-.0646 \\
(0.49)\end{array}$ & $\begin{array}{l}-.1270 \\
(0.72)\end{array}$ & $\begin{array}{l}-.0224 \\
(0.18)\end{array}$ & $\begin{array}{l}-.0577 \\
(0.44)\end{array}$ \\
\hline Loan loss provisions ratio & $\begin{array}{l}-.0268 \\
(5.19) * * *\end{array}$ & $\begin{array}{l}.0132 \\
(4.61)^{* * *}\end{array}$ & $\begin{array}{l}.0087 \\
(2.69)^{* * * *}\end{array}$ & $\begin{array}{l}-.0262 \\
(5.15)^{* * *}\end{array}$ & $\begin{array}{l}.0126 \\
(4.71)^{* * *}\end{array}$ & $\begin{array}{l}.0081 \\
(2.70)^{* * *}\end{array}$ \\
\hline Liquidity ratio & $\begin{array}{l}-.0093 \\
(4.43)^{* * *}\end{array}$ & $\begin{array}{l}.0154 \\
(4.64)^{* * *}\end{array}$ & $\begin{array}{l}.0229 \\
(5.41)^{* * * *}\end{array}$ & $\begin{array}{l}-.0091 \\
(4.20)^{* * *}\end{array}$ & $\begin{array}{l}.0151 \\
(4.92)^{* * *}\end{array}$ & $\begin{array}{l}.0225 \\
(5.68)^{* * *}\end{array}$ \\
\hline Governance index & & & & $\begin{array}{l}-.0054 \\
(0.95)\end{array}$ & $\begin{array}{l}.0063 \\
(1.82)^{*}\end{array}$ & $\begin{array}{l}.0067 \\
(1.66)^{*}\end{array}$ \\
\hline Year dummies & Yes & Yes & Yes & Yes & Yes & Yes \\
\hline Number of clusters & 297 & 297 & 297 & 297 & 297 & 297 \\
\hline Observations & 779 & 779 & 779 & 779 & 779 & 779 \\
\hline Test of endogeneity(p-value) & 0.6246 & 0.0000 & 0.0000 & 0.5280 & 0.0000 & 0.0000 \\
\hline Partial R2 of instruments & 0.0837 & 0.0837 & 0.0837 & 0.0871 & 0.0871 & 0.0871 \\
\hline F-test of instruments (p-value) & 0.0002 & 0.0002 & 0.0002 & 0.0001 & 0.0001 & 0.0001 \\
\hline Hansen J test (p-value) & 0.2677 & 0.2058 & 0.1397 & 0.2569 & 0.1938 & 0.1291 \\
\hline
\end{tabular}


Panel B: With Firm fixed effects

\begin{tabular}{|c|c|c|c|c|c|c|c|c|c|}
\hline \multirow[t]{2}{*}{ Dependent variable } & Z-score & $\begin{array}{l}\text { Standard } \\
\text { deviation of } \\
\text { return }\end{array}$ & $\begin{array}{l}\text { Earnings } \\
\text { volatility }\end{array}$ & Z-score & $\begin{array}{l}\text { Standard } \\
\text { deviation of } \\
\text { return }\end{array}$ & $\begin{array}{l}\text { Earnings } \\
\text { volatility }\end{array}$ & Z-score & $\begin{array}{l}\text { Standard } \\
\text { deviation of } \\
\text { return }\end{array}$ & $\begin{array}{l}\text { Earnings } \\
\text { volatility }\end{array}$ \\
\hline & $(1)$ & $(2)$ & (3) & $(4)$ & $(5)$ & $(6)$ & $(7)$ & $(8)$ & (9) \\
\hline SND/RWA & $\begin{array}{l}-.0031 \\
(0.01)\end{array}$ & $\begin{array}{l}-.0739 \\
(0.27)\end{array}$ & $\begin{array}{l}-.2057 \\
(0.66)\end{array}$ & $\begin{array}{l}.0132 \\
(0.02)\end{array}$ & $\begin{array}{l}-.0752 \\
(0.28)\end{array}$ & $\begin{array}{l}-.2070 \\
(0.67)\end{array}$ & $\begin{array}{l}1.400 \\
(2.11)^{* *}\end{array}$ & $\begin{array}{l}-1.727 \\
(1.80)^{*}\end{array}$ & $\begin{array}{l}-1.659 \\
(2.33)^{* *}\end{array}$ \\
\hline Loan growth & $\begin{array}{l}.0042 \\
(1.59)\end{array}$ & $\begin{array}{l}-.0013 \\
(1.01)\end{array}$ & $\begin{array}{l}-.0005 \\
(0.37)\end{array}$ & $\begin{array}{l}.0042 \\
(1.60)\end{array}$ & $\begin{array}{l}-.0013 \\
(1.01)\end{array}$ & $\begin{array}{l}-.0005 \\
(0.37)\end{array}$ & $\begin{array}{l}-.0053 \\
(3.07)^{* * *}\end{array}$ & $\begin{array}{l}.0079 \\
(4.06)^{* * *}\end{array}$ & $\begin{array}{l}.0080 \\
(4.07)^{* * * *}\end{array}$ \\
\hline Size & $\begin{array}{l}-.9780 \\
(2.07)^{* *}\end{array}$ & $\begin{array}{l}.3213 \\
(1.47)\end{array}$ & $\begin{array}{l}.1807 \\
(0.76)\end{array}$ & $\begin{array}{l}-.9864 \\
(2.08)^{* *}\end{array}$ & $\begin{array}{l}.3222 \\
(1.46)\end{array}$ & $\begin{array}{l}.1821 \\
(0.76)\end{array}$ & $\begin{array}{l}.9614 \\
(3.36)^{* * *}\end{array}$ & $\begin{array}{l}-1.321 \\
(3.07)^{* * *}\end{array}$ & $\begin{array}{l}-1.164 \\
(4.06)^{* * * *}\end{array}$ \\
\hline Demand deposits ratio & $\begin{array}{l}-.0001 \\
(0.01)\end{array}$ & $\begin{array}{l}-.0041 \\
(1.38)\end{array}$ & $\begin{array}{l}-.0057 \\
(1.70)^{*}\end{array}$ & $\begin{array}{l}-.0002 \\
(0.02)\end{array}$ & $\begin{array}{l}-.0041 \\
(1.37)\end{array}$ & $\begin{array}{l}-.0057 \\
(1.70)^{*}\end{array}$ & $\begin{array}{l}.0012 \\
(0.12)\end{array}$ & $\begin{array}{l}.0025 \\
(0.27)\end{array}$ & $\begin{array}{l}.0007 \\
(0.08)\end{array}$ \\
\hline Loan loss provisions ratio & $\begin{array}{l}-.0081 \\
(1.14)\end{array}$ & $\begin{array}{l}.0051 \\
(1.44)\end{array}$ & $\begin{array}{l}.0043 \\
(1.12)\end{array}$ & $\begin{array}{l}-.0084 \\
(1.17)\end{array}$ & $\begin{array}{l}.0052 \\
(1.46)\end{array}$ & $\begin{array}{l}.0043 \\
(1.12)\end{array}$ & $\begin{array}{l}-.0232 \\
(5.45)^{* * *}\end{array}$ & $\begin{array}{l}.0154 \\
(3.48)^{* * *}\end{array}$ & $\begin{array}{l}.0134 \\
(3.59)^{* * *}\end{array}$ \\
\hline Liquidity ratio & $\begin{array}{l}-.0263 \\
(1.09)\end{array}$ & $\begin{array}{l}.0088 \\
(0.75)\end{array}$ & $\begin{array}{l}.0198 \\
(1.44)\end{array}$ & $\begin{array}{l}-.0266 \\
(1.09)\end{array}$ & $\begin{array}{l}.0088 \\
(0.75)\end{array}$ & $\begin{array}{l}.0198 \\
(1.44)\end{array}$ & $\begin{array}{l}-.0168 \\
(1.41)\end{array}$ & $\begin{array}{l}.0080 \\
(0.83)\end{array}$ & $\begin{array}{l}.0141 \\
(1.53)\end{array}$ \\
\hline Governance index & & & & $\begin{array}{l}.0109 \\
(0.69)\end{array}$ & $\begin{array}{l}-.0011 \\
(0.17)\end{array}$ & $\begin{array}{l}-.0015 \\
(0.24)\end{array}$ & & & \\
\hline Year dummies & Yes & Yes & Yes & Yes & Yes & Yes & Yes & Yes & Yes \\
\hline Firm fixed effects & Yes & Yes & Yes & Yes & Yes & Yes & Yes & Yes & Yes \\
\hline Number of clusters & 297 & 297 & 297 & 297 & 297 & 297 & 483 & 483 & 483 \\
\hline Observations & 779 & 779 & 779 & 779 & 779 & 779 & 1546 & 1546 & 1546 \\
\hline Test of endogeneity (p-value) & 0.6638 & 0.5031 & 0.4091 & 0.6477 & 0.4997 & 0.4070 & 0.0085 & 0.0393 & 0.0054 \\
\hline Partial R2 of instruments & 0.0246 & 0.0246 & 0.0246 & 0.0241 & 0.0241 & 0.0241 & 0.0135 & 0.0135 & 0.0135 \\
\hline F-test of instruments ( $\mathrm{p}$-value) & 0.0502 & 0.0502 & 0.0502 & 0.0526 & 0.0526 & 0.0526 & 0.0046 & 0.0046 & 0.0046 \\
\hline Hansen $J$ test (p-value) & 0.0960 & 0.0992 & 0.2632 & 0.1075 & 0.1002 & 0.2633 & 0.0185 & 0.3059 & 0.4816 \\
\hline
\end{tabular}




\section{Table XIV: When Subordinated Debt Is Not Expected to Exert Market Discipline Effects}

Panel A examines the effect of subordinated debt in state-owned banks and Panels B-D examine the effect of subordinated debt in too-big-to-fail banks by including a dummy variable for the type of banking firms in question and an interaction term between the SND ratio and the corresponding dummy. Dependent variable is z-score in Columns (1)-(3), standard deviation of return in Columns (4)-(6), and earnings volatility in Columns (7)-(9). Regressors are lagged by one year. All regressions are estimated using 2SLS, where Columns (1), (4) and (7) report the results for the High subsample on Disclosure-insurance index (High DI); Columns (2), (5) and (8) report the results for the High subsample on Supervisory power index (High SP); and Columns (3), (6) and (9) report the results for the High subsample on Economic development (High ED). The IVs for SND/RWA are the average SND ratio of other banks in the same country, year, and size group, the lagged capital-to-assets ratio, and the average tax rate. The IVs for the interaction term between the SND ratio and the state-owned/too-big-to-fail dummy are the interaction terms between the state-owned/too-big-to-fail dummy and each of the three variables: the average SND ratio of other banks in the same country, year and size group, the bank's lagged capital-to-assets ratio, and the bank's average tax rate. See Table I for variable definition. Also included are the p-value of the regression-based test of endogeneity, the partial R2 of excluded instruments in the first-stage estimation of SND/RWA, the p-value of the F-test of excluded instruments in the first-stage estimation of $\mathrm{SND} / \mathrm{RWA}$, and the p-value of the Hansen $\mathrm{J}$ test of overidentification. Also reported at the bottom of each panel is the p-value of the test of the null hypothesis that the sum of the coefficients on the SND ratio and on the interaction term between the SND ratio and the corresponding dummy is zero. Standard errors are clustered at the country level. z-statistics are reported in parentheses. *, **, and *** indicate significance at the $10 \%, 5 \%$, and $1 \%$ levels, respectively.

\section{Panel A: State-owned banking firms}

\begin{tabular}{|c|c|c|c|c|c|c|c|c|c|}
\hline \multirow[t]{2}{*}{ Dependent variable: } & \multicolumn{3}{|c|}{ Z-score } & \multicolumn{3}{|c|}{ Standard deviation of return } & \multicolumn{3}{|c|}{ Earnings volatility } \\
\hline & High DI & High SP & High ED & High DI & High SP & High ED & High DI & High SP & High ED \\
\hline & $(1)$ & $(2)$ & (3) & (4) & $(5)$ & $(6)$ & $(7)$ & $(8)$ & (9) \\
\hline SND/RWA & $\begin{array}{l}.2685 \\
(4.83) * * *\end{array}$ & $\begin{array}{l}.2967 \\
(8.19)^{* * * *}\end{array}$ & $\begin{array}{l}.3139 \\
(4.35)^{* * * *}\end{array}$ & $\begin{array}{l}-1.099 \\
(6.70)^{* * * *}\end{array}$ & $\begin{array}{l}-1.162 \\
(21.33) * * *\end{array}$ & $\begin{array}{l}-1.138 \\
(6.78)^{* * * *}\end{array}$ & $\begin{array}{l}-.9665 \\
(8.28)^{* * *}\end{array}$ & $\begin{array}{l}-.9903 \\
(26.20)^{* * *}\end{array}$ & $\begin{array}{l}-1.016 \\
(9.33)^{* * * *}\end{array}$ \\
\hline SND/RWA*State dummy & $\begin{array}{l}-.5681 \\
(2.81)^{* * *}\end{array}$ & $\begin{array}{l}-1.012 \\
(1.93)^{*}\end{array}$ & $\begin{array}{l}-.3338 \\
(2.38)^{* *}\end{array}$ & $\begin{array}{l}.9143 \\
(5.98)^{* * *}\end{array}$ & $\begin{array}{l}1.098 \\
(3.10) * * *\end{array}$ & $\begin{array}{l}.8177 \\
(4.07)^{* * * *}\end{array}$ & $\begin{array}{l}.7964 \\
(5.98) * * *\end{array}$ & $\begin{array}{l}1.157 \\
(3.76) * * *\end{array}$ & $\begin{array}{l}.7398 \\
(4.00)^{* * *}\end{array}$ \\
\hline State dummy & $\begin{array}{l}1.302 \\
(3.09)^{* * *}\end{array}$ & $\begin{array}{l}1.453 \\
(1.10)\end{array}$ & $\begin{array}{l}.7455 \\
(1.29)\end{array}$ & $\begin{array}{l}-2.788 \\
(8.05)^{* * *}\end{array}$ & $\begin{array}{l}-2.506 \\
(3.53)^{* * *}\end{array}$ & $\begin{array}{l}-2.919 \\
(4.86)^{* * *}\end{array}$ & $\begin{array}{l}-2.376 \\
(8.90)^{* * *}\end{array}$ & $\begin{array}{l}-2.361 \\
(3.44)^{* * *}\end{array}$ & $\begin{array}{l}-2.626 \\
(5.23)^{* * * *}\end{array}$ \\
\hline Loan growth & $\begin{array}{l}-.0122 \\
(11.69)^{* * *}\end{array}$ & $\begin{array}{l}-.0106 \\
(5.59)^{* * *}\end{array}$ & $\begin{array}{l}-.0125 \\
(15.14) * * *\end{array}$ & $\begin{array}{l}.0150 \\
(7.14)^{* * *}\end{array}$ & $\begin{array}{l}.0137 \\
(4.99) * * *\end{array}$ & $\begin{array}{l}.0153 \\
(9.22)^{* * * *}\end{array}$ & $\begin{array}{l}.0144 \\
(8.29) * * *\end{array}$ & $\begin{array}{l}.0129 \\
(5.96) * * *\end{array}$ & $\begin{array}{l}.0147 \\
(11.01)^{* * * *}\end{array}$ \\
\hline Size & $\begin{array}{l}-.0081 \\
(0.59)\end{array}$ & $\begin{array}{l}-.0123 \\
(0.73)\end{array}$ & $\begin{array}{l}-.0282 \\
(1.80)^{*}\end{array}$ & $\begin{array}{l}.2951 \\
(3.09)^{* * *}\end{array}$ & $\begin{array}{l}.3538 \\
(10.09)^{* * *}\end{array}$ & $\begin{array}{l}.3113 \\
(3.30)^{* * * *}\end{array}$ & $\begin{array}{l}.2508 \\
(3.17)^{* * *}\end{array}$ & $\begin{array}{l}.2958 \\
(12.48)^{* * *}\end{array}$ & $\begin{array}{l}.2698 \\
(3.66) * * *\end{array}$ \\
\hline Demand deposits ratio & $\begin{array}{l}.0016 \\
(0.51)\end{array}$ & $\begin{array}{l}.0066 \\
(3.09)^{* * *}\end{array}$ & $\begin{array}{l}.0009 \\
(0.21)\end{array}$ & $\begin{array}{l}.0002 \\
(0.06)\end{array}$ & $\begin{array}{l}-.0042 \\
(1.33)\end{array}$ & $\begin{array}{l}-.0018 \\
(0.79)\end{array}$ & $\begin{array}{l}.0000 \\
(0.01)\end{array}$ & $\begin{array}{l}-.0037 \\
(1.56)\end{array}$ & $\begin{array}{l}-.0017 \\
(0.85)\end{array}$ \\
\hline Independence dummy & $\begin{array}{l}.0275 \\
(0.61)\end{array}$ & $\begin{array}{l}.1296 \\
(1.85)^{*}\end{array}$ & $\begin{array}{l}.0260 \\
(0.65)\end{array}$ & $\begin{array}{l}.1227 \\
(1.69)^{*}\end{array}$ & $\begin{array}{l}-.0042 \\
(0.12)\end{array}$ & $\begin{array}{l}.0984 \\
(1.55)\end{array}$ & $\begin{array}{l}.1654 \\
(2.27)^{* *}\end{array}$ & $\begin{array}{l}.0658 \\
(3.68)^{* * *}\end{array}$ & $\begin{array}{l}.1347 \\
(2.21)^{* *}\end{array}$ \\
\hline
\end{tabular}




\begin{tabular}{|c|c|c|c|c|c|c|c|c|c|}
\hline Loan loss provisions ratio & $\begin{array}{l}-.0232 \\
(3.49)^{* * *}\end{array}$ & $\begin{array}{l}-.0240 \\
(3.16)^{* * *}\end{array}$ & $\begin{array}{l}-.0305 \\
(3.97)^{* * *}\end{array}$ & $\begin{array}{l}.0168 \\
(3.35)^{* * *}\end{array}$ & $\begin{array}{l}.0169 \\
(3.60)^{* * *}\end{array}$ & $\begin{array}{l}.0239 \\
(5.26)^{* * *}\end{array}$ & $\begin{array}{l}.0118 \\
(2.21)^{* *}\end{array}$ & $\begin{array}{l}.0125 \\
(2.85)^{* * * *}\end{array}$ & $\begin{array}{l}.0197 \\
(4.77)^{* * * *}\end{array}$ \\
\hline Liquidity ratio & $\begin{array}{l}-.0081 \\
(1.89)^{*}\end{array}$ & $\begin{array}{l}-.0128 \\
(5.46) * * *\end{array}$ & $\begin{array}{l}-.0081 \\
(1.91)^{*}\end{array}$ & $\begin{array}{l}.0095 \\
(2.23)^{* *}\end{array}$ & $\begin{array}{l}.0136 \\
(4.71)^{* * * *}\end{array}$ & $\begin{array}{l}.0105 \\
(2.64)^{* * * *}\end{array}$ & $\begin{array}{l}.0134 \\
(2.12)^{* *}\end{array}$ & $\begin{array}{l}.0212 \\
(6.74)^{* * * *}\end{array}$ & $\begin{array}{l}.0141 \\
(2.31)^{* *}\end{array}$ \\
\hline GDP per capita & $\begin{array}{l}.8274 \\
(0.96)\end{array}$ & $\begin{array}{l}.7302 \\
(1.27)\end{array}$ & $\begin{array}{l}.6785 \\
(1.03)\end{array}$ & $\begin{array}{l}-1.349 \\
(0.87)\end{array}$ & $\begin{array}{l}-1.605 \\
(1.77)^{*}\end{array}$ & $\begin{array}{l}-2.074 \\
(1.64)\end{array}$ & $\begin{array}{l}-1.283 \\
(0.96)\end{array}$ & $\begin{array}{l}-1.634 \\
(1.69)^{*}\end{array}$ & $\begin{array}{l}-1.591 \\
(1.44)\end{array}$ \\
\hline Capital regulation index & $\begin{array}{l}.0933 \\
(1.48)\end{array}$ & $\begin{array}{l}.0191 \\
(0.21)\end{array}$ & $\begin{array}{l}.1232 \\
(2.23)^{* *}\end{array}$ & $\begin{array}{l}-.1439 \\
(1.07)\end{array}$ & $\begin{array}{l}.1558 \\
(1.34)\end{array}$ & $\begin{array}{l}-.3649 \\
(4.05) * * *\end{array}$ & $\begin{array}{l}-.1553 \\
(1.66)^{*}\end{array}$ & $\begin{array}{l}.0949 \\
(0.84)\end{array}$ & $\begin{array}{l}-.2949 \\
(3.62) * * *\end{array}$ \\
\hline Supervisory power index & $\begin{array}{l}-.0305 \\
(0.52)\end{array}$ & $\begin{array}{l}.0883 \\
(0.58)\end{array}$ & $\begin{array}{l}-.1260 \\
(1.85)^{*}\end{array}$ & $\begin{array}{l}.0080 \\
(0.08)\end{array}$ & $\begin{array}{l}.1028 \\
(0.35)\end{array}$ & $\begin{array}{l}-.0393 \\
(0.39)\end{array}$ & $\begin{array}{l}-.0332 \\
(0.39)\end{array}$ & $\begin{array}{l}-.1244 \\
(0.44)\end{array}$ & $\begin{array}{l}-.0466 \\
(0.49)\end{array}$ \\
\hline Disclosure-insurance index & $\begin{array}{l}.0886 \\
(0.31)\end{array}$ & $\begin{array}{l}-.0492 \\
(0.29)\end{array}$ & $\begin{array}{l}-.0225 \\
(0.14)\end{array}$ & $\begin{array}{l}-.0370 \\
(0.09)\end{array}$ & $\begin{array}{l}.5566 \\
(2.42)^{* *}\end{array}$ & $\begin{array}{l}.3794 \\
(1.34)\end{array}$ & $\begin{array}{l}.0864 \\
(0.27)\end{array}$ & $\begin{array}{l}.2525 \\
(1.26)\end{array}$ & $\begin{array}{l}.3348 \\
(1.35)\end{array}$ \\
\hline Country dummies & Yes & Yes & Yes & Yes & Yes & Yes & Yes & Yes & Yes \\
\hline Year dummies & Yes & Yes & Yes & Yes & Yes & Yes & Yes & Yes & Yes \\
\hline Number of clusters & 40 & 28 & 31 & 40 & 28 & 31 & 40 & 28 & 31 \\
\hline Observations & 2048 & 1762 & 1966 & 2048 & 1762 & 1966 & 2048 & 1761 & 1965 \\
\hline Test of endogeneity ( $p$-value) & 0.0000 & 0.0000 & 0.0000 & 0.0000 & 0.0000 & 0.0000 & 0.0000 & 0.0000 & 0.0000 \\
\hline Partial R2 of instruments & 0.0654 & 0.0678 & 0.0649 & 0.0654 & 0.0678 & 0.0640 & 0.0654 & 0.0676 & 0.0638 \\
\hline F-test of instruments ( $p$-value) & 0.0000 & 0.0000 & 0.0000 & 0.0000 & 0.0000 & 0.0000 & 0.0000 & 0.0000 & 0.0000 \\
\hline Hansen $\mathbf{J}$ test (p-value) & 0.7921 & 0.7034 & 0.5642 & 0.0580 & 0.3756 & 0.1089 & 0.0424 & 0.4799 & 0.2069 \\
\hline$($ Row1 + Row2 $)=0(p$-value $)$ & 0.0948 & 0.1814 & 0.8750 & 0.2304 & 0.8650 & 0.0215 & 0.1759 & 0.6017 & 0.0486 \\
\hline
\end{tabular}


Panel B: Too-big-to-fail banking firms (The bank's share in the country's total deposits exceeds 10\%)

\begin{tabular}{|c|c|c|c|c|c|c|c|c|c|}
\hline \multirow[t]{3}{*}{ Dependent variable: } & \multicolumn{3}{|c|}{ Z-score } & \multicolumn{3}{|c|}{ Standard deviation of return } & \multicolumn{3}{|c|}{ Earnings volatility } \\
\hline & High DI & High SP & High ED & High DI & High SP & High ED & High DI & High SP & High ED \\
\hline & $(1)$ & $(2)$ & $(3)$ & $(4)$ & $(5)$ & $(6)$ & $(7)$ & $(8)$ & $(9)$ \\
\hline SND/RWA & $\begin{array}{l}.2660 \\
(4.27)^{* * *}\end{array}$ & $\begin{array}{l}.3477 \\
(6.84)^{* * *}\end{array}$ & $\begin{array}{l}.3148 \\
(4.94)^{* * *}\end{array}$ & $\begin{array}{l}-.9412 \\
(4.24)^{* * *}\end{array}$ & $\begin{array}{l}-1.034 \\
(11.59)^{* * *}\end{array}$ & $\begin{array}{l}-.9779 \\
(4.96)^{* * *}\end{array}$ & $\begin{array}{l}-.8105 \\
(4.43)^{* * *}\end{array}$ & $\begin{array}{l}-.8569 \\
(10.84)^{* * *}\end{array}$ & $\begin{array}{l}-.8723 \\
(5.99)^{* * *}\end{array}$ \\
\hline SND/RWA*TBTF dummy & $\begin{array}{l}-.2269 \\
(2.26)^{* *}\end{array}$ & $\begin{array}{l}-.0032 \\
(0.01)\end{array}$ & $\begin{array}{l}-.4262 \\
(1.81)^{*}\end{array}$ & $\begin{array}{l}.1553 \\
(0.79)\end{array}$ & $\begin{array}{l}.3017 \\
(1.07)\end{array}$ & $\begin{array}{l}1.413 \\
(5.01)^{* * *}\end{array}$ & $\begin{array}{l}.0830 \\
(0.48)\end{array}$ & $\begin{array}{l}.2729 \\
(1.95)^{*}\end{array}$ & $\begin{array}{l}1.267 \\
(5.71)^{* * *}\end{array}$ \\
\hline TBTF dummy & $\begin{array}{l}.6991 \\
(2.14)^{* *}\end{array}$ & $\begin{array}{l}.2971 \\
(0.39)\end{array}$ & $\begin{array}{l}1.413 \\
(1.59)\end{array}$ & $\begin{array}{l}-.9915 \\
(1.68)^{*}\end{array}$ & $\begin{array}{l}-1.633 \\
(1.93)^{*}\end{array}$ & $\begin{array}{l}-5.962 \\
(4.76)^{* * *}\end{array}$ & $\begin{array}{l}-.6583 \\
(1.38)\end{array}$ & $\begin{array}{l}-1.261 \\
(2.78) * * *\end{array}$ & $\begin{array}{l}-5.395 \\
(5.42)^{* * *}\end{array}$ \\
\hline Loan growth & $\begin{array}{l}-.0120 \\
(10.55)^{* * *}\end{array}$ & $\begin{array}{l}-.0119 \\
(11.19)^{* * *}\end{array}$ & $\begin{array}{l}-.0124 \\
(16.77)^{* * *}\end{array}$ & $\begin{array}{l}.0141 \\
(5.89)^{* * *}\end{array}$ & $\begin{array}{l}.0142 \\
(7.30)^{* * *}\end{array}$ & $\begin{array}{l}.0146 \\
(8.94)^{* * *}\end{array}$ & $\begin{array}{l}.0136 \\
(6.89)^{* * * *}\end{array}$ & $\begin{array}{l}.0134 \\
(8.93) * * *\end{array}$ & $\begin{array}{l}.0141 \\
(11.09)^{*} * *\end{array}$ \\
\hline Size & $\begin{array}{l}-.0051 \\
(0.28)\end{array}$ & $\begin{array}{l}-.0350 \\
(1.55)\end{array}$ & $\begin{array}{l}-.0203 \\
(1.20)\end{array}$ & $\begin{array}{l}.2628 \\
(2.63)^{* * *}\end{array}$ & $\begin{array}{l}.3245 \\
(9.34)^{* * *}\end{array}$ & $\begin{array}{l}.2723 \\
(2.97)^{* * *}\end{array}$ & $\begin{array}{l}.2160 \\
(2.45)^{* *}\end{array}$ & $\begin{array}{l}.2616 \\
(8.13)^{* * *}\end{array}$ & $\begin{array}{l}.2357 \\
(3.13)^{* * *}\end{array}$ \\
\hline Demand deposits ratio & $\begin{array}{l}.0024 \\
(0.85)\end{array}$ & $\begin{array}{l}.0078 \\
(3.57)^{* * *}\end{array}$ & $\begin{array}{l}.0011 \\
(0.26)\end{array}$ & $\begin{array}{l}.0001 \\
(0.05)\end{array}$ & $\begin{array}{l}-.0052 \\
(2.17)^{* *}\end{array}$ & $\begin{array}{l}.0003 \\
(0.11)\end{array}$ & $\begin{array}{l}-.0000 \\
(0.02)\end{array}$ & $\begin{array}{l}-.0046 \\
(2.81)^{* * *}\end{array}$ & $\begin{array}{l}.0002 \\
(0.09)\end{array}$ \\
\hline Independence dummy & $\begin{array}{l}.0233 \\
(0.61)\end{array}$ & $\begin{array}{l}.0619 \\
(2.64)^{* * *}\end{array}$ & $\begin{array}{l}.0093 \\
(0.24)\end{array}$ & $\begin{array}{l}.0666 \\
(1.40)\end{array}$ & $\begin{array}{l}-.0271 \\
(0.57)\end{array}$ & $\begin{array}{l}.0775 \\
(1.70)^{*}\end{array}$ & $\begin{array}{l}.1145 \\
(2.45)^{* *}\end{array}$ & $\begin{array}{l}.0460 \\
(1.93)^{*}\end{array}$ & $\begin{array}{l}.1193 \\
(2.71)^{* * *}\end{array}$ \\
\hline Loan loss provisions ratio & $\begin{array}{l}-.0241 \\
(3.26)^{* * *}\end{array}$ & $\begin{array}{l}-.0247 \\
(2.93)^{* * *}\end{array}$ & $\begin{array}{l}-.0357 \\
(6.67)^{* * *}\end{array}$ & $\begin{array}{l}.0156 \\
(2.70)^{* * *}\end{array}$ & $\begin{array}{l}.0156 \\
(2.79)^{* * *}\end{array}$ & $\begin{array}{l}.0248 \\
(5.87)^{* * *}\end{array}$ & $\begin{array}{l}.0105 \\
(1.67)^{*}\end{array}$ & $\begin{array}{l}.0108 \\
(1.85)^{*}\end{array}$ & $\begin{array}{l}.0209 \\
(5.66)^{* * *}\end{array}$ \\
\hline Liquidity ratio & $\begin{array}{l}-.0074 \\
(1.59)\end{array}$ & $\begin{array}{l}-.0144 \\
(9.57)^{* * *}\end{array}$ & $\begin{array}{l}-.0068 \\
(1.51)\end{array}$ & $\begin{array}{l}.0093 \\
(2.06)^{* *}\end{array}$ & $\begin{array}{l}.0149 \\
(7.14)^{* * *}\end{array}$ & $\begin{array}{l}.0083 \\
(1.77)^{*}\end{array}$ & $\begin{array}{l}.0134 \\
(1.99)^{* *}\end{array}$ & $\begin{array}{l}.0225 \\
(8.82)^{* * *}\end{array}$ & $\begin{array}{l}.0122 \\
(1.76)^{*}\end{array}$ \\
\hline GDP per capita & $\begin{array}{l}.8248 \\
(0.83)\end{array}$ & $\begin{array}{l}-1.745 \\
(1.09)\end{array}$ & $\begin{array}{l}.6067 \\
(0.91)\end{array}$ & $\begin{array}{l}-2.388 \\
(1.50)\end{array}$ & $\begin{array}{l}.3330 \\
(0.17)\end{array}$ & $\begin{array}{l}-1.720 \\
(1.27)\end{array}$ & $\begin{array}{l}-2.416 \\
(1.92)^{*}\end{array}$ & $\begin{array}{l}-.1443 \\
(0.09)\end{array}$ & $\begin{array}{l}-1.305 \\
(1.15)\end{array}$ \\
\hline Capital regulation index & $\begin{array}{l}.1575 \\
(2.77)^{* * *}\end{array}$ & $\begin{array}{l}1.137 \\
(5.03)^{* * *}\end{array}$ & $\begin{array}{l}.1897 \\
(4.27)^{* * *}\end{array}$ & $\begin{array}{l}-.2016 \\
(1.29)\end{array}$ & $\begin{array}{l}-.9905 \\
(3.01)^{* * *}\end{array}$ & $\begin{array}{l}-.3815 \\
(3.08)^{* * *}\end{array}$ & $\begin{array}{l}-.2000 \\
(1.83)^{*}\end{array}$ & $\begin{array}{l}-.9937 \\
(3.49)^{* * *}\end{array}$ & $\begin{array}{l}-.3118 \\
(2.87)^{* * *}\end{array}$ \\
\hline Supervisory power index & $\begin{array}{l}-.0401 \\
(0.53)\end{array}$ & $\begin{array}{l}.0898 \\
(1.11)\end{array}$ & $\begin{array}{l}-.1734 \\
(3.52)^{* * *}\end{array}$ & $\begin{array}{l}.0749 \\
(1.11)\end{array}$ & $\begin{array}{l}.2286 \\
(2.25)^{* *}\end{array}$ & $\begin{array}{l}.0657 \\
(0.85)\end{array}$ & $\begin{array}{l}.0351 \\
(0.73)\end{array}$ & $\begin{array}{l}.0287 \\
(0.32)\end{array}$ & $\begin{array}{l}.0443 \\
(0.63)\end{array}$ \\
\hline Disclosure-insurance index & $\begin{array}{l}.1428 \\
(0.53)\end{array}$ & $\begin{array}{l}-.3484 \\
(1.96)^{* *}\end{array}$ & $\begin{array}{l}.1171 \\
(1.05)\end{array}$ & $\begin{array}{l}-.0531 \\
(0.14)\end{array}$ & $\begin{array}{l}.7174 \\
(4.55)^{* * * *}\end{array}$ & $\begin{array}{l}-.0051 \\
(0.02)\end{array}$ & $\begin{array}{l}.0972 \\
(0.37)\end{array}$ & $\begin{array}{l}.4799 \\
(5.90)^{* * *}\end{array}$ & $\begin{array}{l}.0039 \\
(0.02)\end{array}$ \\
\hline Country dummies & Yes & Yes & Yes & Yes & Yes & Yes & Yes & Yes & Yes \\
\hline Year dummies & Yes & Yes & Yes & Yes & Yes & Yes & Yes & Yes & Yes \\
\hline Number of clusters & 37 & 24 & 27 & 37 & 24 & 27 & 37 & 24 & 27 \\
\hline Observations & 2003 & 1711 & 1941 & 2003 & 1711 & 1941 & 2003 & 1710 & 1940 \\
\hline Test of endogeneity (p-value) & 0.0000 & 0.0000 & 0.0000 & 0.0000 & 0.0000 & 0.0000 & 0.0000 & 0.0000 & 0.0000 \\
\hline Partial R2 of instruments & 0.0737 & 0.0857 & 0.0837 & 0.0737 & 0.0857 & 0.0837 & 0.0737 & 0.0856 & 0.0836 \\
\hline F-test of instruments (p-value) & 0.0000 & 0.0000 & 0.0000 & 0.0000 & 0.0000 & 0.0000 & 0.0000 & 0.0000 & 0.0000 \\
\hline Hansen J test (p-value) & 0.7895 & 0.3118 & 0.7123 & 0.0429 & 0.1608 & 0.3043 & 0.0308 & 0.0812 & 0.3187 \\
\hline$($ Row1 + Row2 $)=0(p$-value $)$ & 0.7732 & 0.1053 & 0.6369 & 0.0168 & 0.0176 & 0.1352 & 0.0136 & 0.0002 & 0.1225 \\
\hline
\end{tabular}


Panel C: Too-big-to-fail banking firms (The bank's share in the country's total deposits exceeds 15\%)

\begin{tabular}{|c|c|c|c|c|c|c|c|c|c|}
\hline \multirow[t]{2}{*}{ Dependent variable: } & \multicolumn{3}{|c|}{ Z-score } & \multicolumn{3}{|c|}{ Standard deviation of return } & \multicolumn{3}{|c|}{ Earnings volatility } \\
\hline & High DI & High SP & High ED & High DI & High SP & High ED & High DI & High SP & High ED \\
\hline & $(1)$ & $(2)$ & (3) & $(4)$ & $(5)$ & $(6)$ & $(7)$ & $(8)$ & $(9)$ \\
\hline SND/RWA & $\begin{array}{l}.2638 \\
(3.85)^{* * *}\end{array}$ & $\begin{array}{l}.3639 \\
(6.79)^{* * *}\end{array}$ & $\begin{array}{l}.3307 \\
(5.20)^{* * *}\end{array}$ & $\begin{array}{l}-.9937 \\
(4.63)^{* * *}\end{array}$ & $\begin{array}{l}-1.128 \\
(26.61)^{* * *}\end{array}$ & $\begin{array}{l}-1.059 \\
(5.88)^{* * *}\end{array}$ & $\begin{array}{l}-.8696 \\
(5.31)^{* * *}\end{array}$ & $\begin{array}{l}-.9514 \\
(24.70)^{* * *}\end{array}$ & $\begin{array}{l}-.9412 \\
(7.64) * * *\end{array}$ \\
\hline SND/RWA * TBTF dummy & $\begin{array}{l}-.1701 \\
(0.88)\end{array}$ & $\begin{array}{l}-.3052 \\
(1.56)\end{array}$ & $\begin{array}{l}-.3939 \\
(1.68)^{*}\end{array}$ & $\begin{array}{l}.3386 \\
(1.04)\end{array}$ & $\begin{array}{l}.9490 \\
(4.54)^{* * * *}\end{array}$ & $\begin{array}{l}1.074 \\
(4.06)^{* * *}\end{array}$ & $\begin{array}{l}.2793 \\
(0.96)\end{array}$ & $\begin{array}{l}.8075 \\
(6.68)^{* * *}\end{array}$ & $\begin{array}{l}.9048 \\
(4.07)^{* * *}\end{array}$ \\
\hline Loan growth & $\begin{array}{l}-.0120 \\
(9.79)^{* * *}\end{array}$ & $\begin{array}{l}-.0111 \\
(6.66)^{* * *}\end{array}$ & $\begin{array}{l}-.0127 \\
(18.61)^{* * *}\end{array}$ & $\begin{array}{l}.0140 \\
(5.33)^{* * *}\end{array}$ & $\begin{array}{l}.0137 \\
(5.60) * * *\end{array}$ & $\begin{array}{l}.0151 \\
(10.15)^{* * *}\end{array}$ & $\begin{array}{l}.0135 \\
(6.29)^{* * *}\end{array}$ & $\begin{array}{l}.0129 \\
(6.55)^{* * *}\end{array}$ & $\begin{array}{l}.0145 \\
(12.28)^{* * *}\end{array}$ \\
\hline Size & $\begin{array}{l}-.0087 \\
(0.45)\end{array}$ & $\begin{array}{l}-.0401 \\
(1.76)^{*}\end{array}$ & $\begin{array}{l}-.0388 \\
(2.00)^{* *}\end{array}$ & $\begin{array}{l}.2659 \\
(2.50)^{* *}\end{array}$ & $\begin{array}{l}.3497 \\
(16.90) * * *\end{array}$ & $\begin{array}{l}.2932 \\
(3.20)^{* * * *}\end{array}$ & $\begin{array}{l}.2233 \\
(2.49)^{* *}\end{array}$ & $\begin{array}{l}.2888 \\
(17.16)^{* * *}\end{array}$ & $\begin{array}{l}.2531 \\
(3.48)^{* * *}\end{array}$ \\
\hline Demand deposits ratio & $\begin{array}{l}.0021 \\
(0.68)\end{array}$ & $\begin{array}{l}.0072 \\
(3.34)^{* * *}\end{array}$ & $\begin{array}{l}.0011 \\
(0.24)\end{array}$ & $\begin{array}{l}-.0002 \\
(0.08)\end{array}$ & $\begin{array}{l}-.0051 \\
(1.74)^{*}\end{array}$ & $\begin{array}{l}-.0011 \\
(0.55)\end{array}$ & $\begin{array}{l}-.0003 \\
(0.14)\end{array}$ & $\begin{array}{l}-.0045 \\
(2.00)^{* *}\end{array}$ & $\begin{array}{l}-.0011 \\
(0.60)\end{array}$ \\
\hline Independence dummy & $\begin{array}{l}.0462 \\
(1.25)\end{array}$ & $\begin{array}{l}.1107 \\
(1.70)^{*}\end{array}$ & $\begin{array}{l}.0289 \\
(0.72)\end{array}$ & $\begin{array}{l}.0696 \\
(1.35)\end{array}$ & $\begin{array}{l}-.0455 \\
(0.72)\end{array}$ & $\begin{array}{l}.0657 \\
(1.46)\end{array}$ & $\begin{array}{l}.1184 \\
(2.40)^{* *}\end{array}$ & $\begin{array}{l}.0339 \\
(0.96)\end{array}$ & $\begin{array}{l}.1064 \\
(2.52)^{* * *}\end{array}$ \\
\hline Loan loss provisions ratio & $\begin{array}{l}-.0222 \\
(3.21)^{* * *}\end{array}$ & $\begin{array}{l}-.0219 \\
(2.84)^{* * *}\end{array}$ & $\begin{array}{l}-.0301 \\
(3.80)^{* * *}\end{array}$ & $\begin{array}{l}.0154 \\
(2.85)^{* * *}\end{array}$ & $\begin{array}{l}.0143 \\
(2.81)^{* * *}\end{array}$ & $\begin{array}{l}.0218 \\
(3.90)^{* * *}\end{array}$ & $\begin{array}{l}.0105 \\
(1.82)^{*}\end{array}$ & $\begin{array}{l}.0098 \\
(1.85)^{*}\end{array}$ & $\begin{array}{l}.0179 \\
(3.47)^{* * *}\end{array}$ \\
\hline Liquidity ratio & $\begin{array}{l}-.0073 \\
(1.64)\end{array}$ & $\begin{array}{l}-.0126 \\
(4.95)^{* * *}\end{array}$ & $\begin{array}{l}-.0075 \\
(1.72)^{*}\end{array}$ & $\begin{array}{l}.0081 \\
(1.73)^{*}\end{array}$ & $\begin{array}{l}.0118 \\
(3.07)^{* * *}\end{array}$ & $\begin{array}{l}.0087 \\
(1.99)^{* *}\end{array}$ & $\begin{array}{l}.0122 \\
(1.79)^{*}\end{array}$ & $\begin{array}{l}.0197 \\
(4.72) * * *\end{array}$ & $\begin{array}{l}.0127 \\
(1.89)^{*}\end{array}$ \\
\hline TBTF dummy & $\begin{array}{l}.5392 \\
(0.81)\end{array}$ & $\begin{array}{l}.9934 \\
(1.52)\end{array}$ & $\begin{array}{l}1.695 \\
(1.76)^{*}\end{array}$ & $\begin{array}{l}-1.340 \\
(1.14)\end{array}$ & $\begin{array}{l}-3.202 \\
(4.39) * * *\end{array}$ & $\begin{array}{l}-4.779 \\
(4.09)^{* * *}\end{array}$ & $\begin{array}{l}-1.089 \\
(1.04)\end{array}$ & $\begin{array}{l}-2.666 \\
(5.12)^{* * * *}\end{array}$ & $\begin{array}{l}-4.100 \\
(4.16)^{* * *}\end{array}$ \\
\hline GDP per capita & $\begin{array}{l}.5751 \\
(0.66)\end{array}$ & $\begin{array}{l}.8001 \\
(1.14)\end{array}$ & $\begin{array}{l}.6652 \\
(0.94)\end{array}$ & $\begin{array}{l}-.8872 \\
(0.60)\end{array}$ & $\begin{array}{l}-1.536 \\
(1.77)^{*}\end{array}$ & $\begin{array}{l}-1.841 \\
(1.48)\end{array}$ & $\begin{array}{l}-.8732 \\
(0.68)\end{array}$ & $\begin{array}{l}-1.551 \\
(1.62)\end{array}$ & $\begin{array}{l}-1.360 \\
(1.24)\end{array}$ \\
\hline Capital regulation index & $\begin{array}{l}.1050 \\
(1.50)\end{array}$ & $\begin{array}{l}.0149 \\
(0.15)\end{array}$ & $\begin{array}{l}.1462 \\
(2.65)^{* * *}\end{array}$ & $\begin{array}{l}-.1435 \\
(0.97)\end{array}$ & $\begin{array}{l}.0313 \\
(0.28)\end{array}$ & $\begin{array}{l}-.3588 \\
(3.66)^{* * *}\end{array}$ & $\begin{array}{l}-.1535 \\
(1.50)\end{array}$ & $\begin{array}{l}.0157 \\
(0.15)\end{array}$ & $\begin{array}{l}-.2848 \\
(3.35)^{* * *}\end{array}$ \\
\hline Supervisory index & $\begin{array}{l}-.0190 \\
(0.31)\end{array}$ & $\begin{array}{l}.0103 \\
(0.07)\end{array}$ & $\begin{array}{l}-.1585 \\
(2.40)^{* *}\end{array}$ & $\begin{array}{l}.0032 \\
(0.04)\end{array}$ & $\begin{array}{l}.3215 \\
(2.01)^{* *}\end{array}$ & $\begin{array}{l}.0635 \\
(1.14)\end{array}$ & $\begin{array}{l}-.0381 \\
(0.51)\end{array}$ & $\begin{array}{l}.0847 \\
(0.45)\end{array}$ & $\begin{array}{l}.0424 \\
(0.74)\end{array}$ \\
\hline Disclosure-insurance index & $\begin{array}{l}.0560 \\
(0.22)\end{array}$ & $\begin{array}{l}-.1454 \\
(0.88)\end{array}$ & $\begin{array}{l}.0704 \\
(0.41)\end{array}$ & $\begin{array}{l}.0170 \\
(0.05)\end{array}$ & $\begin{array}{l}.2832 \\
(1.79)^{*}\end{array}$ & $\begin{array}{l}.0677 \\
(0.32)\end{array}$ & $\begin{array}{l}.1363 \\
(0.47)\end{array}$ & $\begin{array}{l}.0534 \\
(0.58)\end{array}$ & $\begin{array}{l}.0669 \\
(0.35)\end{array}$ \\
\hline Country dummies & Yes & Yes & Yes & Yes & Yes & Yes & Yes & Yes & Yes \\
\hline Year dummies & Yes & Yes & Yes & Yes & Yes & Yes & Yes & Yes & Yes \\
\hline Number of clusters & 40 & 28 & 31 & 40 & 28 & 31 & 40 & 28 & 31 \\
\hline Observations & 2048 & 1762 & 1966 & 2048 & 1762 & 1966 & 2048 & 1761 & 1965 \\
\hline Test of endogeneity(p-value) & 0.0000 & 0.0000 & 0.0000 & 0.0000 & 0.0000 & 0.0000 & 0.0000 & 0.0000 & 0.0000 \\
\hline Partial R2 of instruments & 0.0690 & 0.0734 & 0.0670 & 0.0690 & 0.0734 & 0.0670 & 0.0690 & 0.0733 & 0.0670 \\
\hline F-test of instruments (p-value) & 0.0000 & 0.0000 & 0.0000 & 0.0000 & 0.0000 & 0.0000 & 0.0000 & 0.0000 & 0.0000 \\
\hline Hansen $J$ test (p-value) & 0.6259 & 0.2084 & 0.7736 & 0.0741 & 0.1829 & 0.2077 & 0.0572 & 0.1283 & 0.2099 \\
\hline Row1 + Row2 $=0$ (p-value) & 0.6186 & 0.7426 & 0.8025 & 0.0733 & 0.3929 & 0.9504 & 0.0745 & 0.1668 & 0.8715 \\
\hline
\end{tabular}


Panel D: Too-big-to-fail banking firms (The bank's share in the country's total deposits exceeds 20\%)

\begin{tabular}{|c|c|c|c|c|c|c|c|c|c|}
\hline \multirow[t]{2}{*}{ Dependent variable: } & \multicolumn{3}{|c|}{ Z-score } & \multicolumn{3}{|c|}{ Standard deviation of return } & \multicolumn{3}{|c|}{ Earnings volatility } \\
\hline & High DI & High SP & High ED & High DI & High SP & High ED & High DI & High SP & High ED \\
\hline & $(1)$ & $(2)$ & (3) & $(4)$ & $(5)$ & $(6)$ & $(7)$ & $(8)$ & $(9)$ \\
\hline SND/RWA & $\begin{array}{l}.2596 \\
(3.77)^{* * *}\end{array}$ & $\begin{array}{l}.3674 \\
(6.29)^{* * *}\end{array}$ & $\begin{array}{l}.3235 \\
(4.97)^{* * *}\end{array}$ & $\begin{array}{l}-.9946 \\
(4.61)^{* * *}\end{array}$ & $\begin{array}{l}-1.156 \\
(25.33)^{* * *}\end{array}$ & $\begin{array}{l}-1.070 \\
(6.04)^{* * *}\end{array}$ & $\begin{array}{l}-.8676 \\
(5.22)^{* * *}\end{array}$ & $\begin{array}{l}-.9699 \\
(23.49)^{* * *}\end{array}$ & $\begin{array}{l}-.9529 \\
(7.98)^{* * *}\end{array}$ \\
\hline SND/RWA * TBTF dummy & $\begin{array}{l}-.3403 \\
(1.57)\end{array}$ & $\begin{array}{l}-.3368 \\
(2.00)^{* * *}\end{array}$ & $\begin{array}{l}-.3613 \\
(1.58)\end{array}$ & $\begin{array}{l}.5497 \\
(1.32)\end{array}$ & $\begin{array}{l}1.173 \\
(7.47)^{* * *}\end{array}$ & $\begin{array}{l}1.056 \\
(4.08)^{* * * *}\end{array}$ & $\begin{array}{l}.3440 \\
(0.87)\end{array}$ & $\begin{array}{l}.9526 \\
(8.60)^{* * *}\end{array}$ & $\begin{array}{l}.8918 \\
(3.93)^{* * *}\end{array}$ \\
\hline Loan growth & $\begin{array}{l}-.0120 \\
(9.97)^{* * *}\end{array}$ & $\begin{array}{l}-.0111 \\
(6.72)^{* * * *}\end{array}$ & $\begin{array}{l}-.0126 \\
(18.01)^{* * *}\end{array}$ & $\begin{array}{l}.0140 \\
(5.35)^{* * *}\end{array}$ & $\begin{array}{l}.0139 \\
(5.77)^{* * *}\end{array}$ & $\begin{array}{l}.0151 \\
(9.90)^{* * *}\end{array}$ & $\begin{array}{l}.0135 \\
(6.27)^{* * *}\end{array}$ & $\begin{array}{l}.0130 \\
(6.69)^{* * *}\end{array}$ & $\begin{array}{l}.0145 \\
(12.06)^{* * * *}\end{array}$ \\
\hline Size & $\begin{array}{l}-.0084 \\
(0.43)\end{array}$ & $\begin{array}{l}-.0404 \\
(1.73)^{*}\end{array}$ & $\begin{array}{l}-.0345 \\
(1.90)^{*}\end{array}$ & $\begin{array}{l}.2670 \\
(2.52)^{* *}\end{array}$ & $\begin{array}{l}.3585 \\
(18.82)^{* * *}\end{array}$ & $\begin{array}{l}.2973 \\
(3.28)^{* * *}\end{array}$ & $\begin{array}{l}.2228 \\
(2.46)^{* *}\end{array}$ & $\begin{array}{l}.2933 \\
(18.89)^{* * * *}\end{array}$ & $\begin{array}{l}.2574 \\
(3.61)^{* * *}\end{array}$ \\
\hline Demand deposits ratio & $\begin{array}{l}.0022 \\
(0.70)\end{array}$ & $\begin{array}{l}.0073 \\
(3.31)^{* * *}\end{array}$ & $\begin{array}{l}.0010 \\
(0.23)\end{array}$ & $\begin{array}{l}-.0003 \\
(0.12)\end{array}$ & $\begin{array}{l}-.0055 \\
(1.81)^{*}\end{array}$ & $\begin{array}{l}-.0011 \\
(0.54)\end{array}$ & $\begin{array}{l}-.0003 \\
(0.15)\end{array}$ & $\begin{array}{l}-.0047 \\
(2.05)^{* *}\end{array}$ & $\begin{array}{l}-.0011 \\
(0.58)\end{array}$ \\
\hline Independence dummy & $\begin{array}{l}.0590 \\
(1.57)\end{array}$ & $\begin{array}{l}.1103 \\
(1.72)^{*}\end{array}$ & $\begin{array}{l}.0302 \\
(0.75)\end{array}$ & $\begin{array}{l}.0534 \\
(0.98)\end{array}$ & $\begin{array}{l}-.0498 \\
(0.75)\end{array}$ & $\begin{array}{l}.0703 \\
(1.59)\end{array}$ & $\begin{array}{l}.1116 \\
(2.17)^{* *}\end{array}$ & $\begin{array}{l}.0326 \\
(0.91)\end{array}$ & $\begin{array}{l}.1110 \\
(2.68)^{* * *}\end{array}$ \\
\hline Loan loss provisions ratio & $\begin{array}{l}-.0222 \\
(3.23)^{* * *}\end{array}$ & $\begin{array}{l}-.0218 \\
(2.83)^{* * *}\end{array}$ & $\begin{array}{l}-.0299 \\
(3.78)^{* * *}\end{array}$ & $\begin{array}{l}.0155 \\
(2.89)^{* * *}\end{array}$ & $\begin{array}{l}.0142 \\
(2.74)^{* * * *}\end{array}$ & $\begin{array}{l}.0218 \\
(3.93)^{* * *}\end{array}$ & $\begin{array}{l}.0106 \\
(1.84)^{*}\end{array}$ & $\begin{array}{l}.0096 \\
(1.81)^{*}\end{array}$ & $\begin{array}{l}.0179 \\
(3.50)^{* * * *}\end{array}$ \\
\hline Liquidity ratio & $\begin{array}{l}-.0072 \\
(1.62)\end{array}$ & $\begin{array}{l}-.0128 \\
(5.76)^{* * * *}\end{array}$ & $\begin{array}{l}-.0077 \\
(1.80)^{*}\end{array}$ & $\begin{array}{l}.0081 \\
(1.75)^{*}\end{array}$ & $\begin{array}{l}.0126 \\
(4.14)^{* * * *}\end{array}$ & $\begin{array}{l}.0093 \\
(2.19)^{* *}\end{array}$ & $\begin{array}{l}.0123 \\
(1.82)^{*}\end{array}$ & $\begin{array}{l}.0204 \\
(5.88)^{* * * *}\end{array}$ & $\begin{array}{l}.0132 \\
(2.02)^{* *}\end{array}$ \\
\hline TBTF dummy & $\begin{array}{l}1.233 \\
(1.58)\end{array}$ & $\begin{array}{l}1.077 \\
(1.93)^{*}\end{array}$ & $\begin{array}{l}1.627 \\
(1.70)^{*}\end{array}$ & $\begin{array}{l}-2.215 \\
(1.36)\end{array}$ & $\begin{array}{l}-4.036 \\
(6.42)^{* * *}\end{array}$ & $\begin{array}{l}-4.905 \\
(4.26)^{* * *}\end{array}$ & $\begin{array}{l}-1.379 \\
(0.92)\end{array}$ & $\begin{array}{l}-3.132 \\
(5.37)^{* * *}\end{array}$ & $\begin{array}{l}-4.234 \\
(4.28)^{* * *}\end{array}$ \\
\hline GDP per capita & $\begin{array}{l}.7270 \\
(0.88)\end{array}$ & $\begin{array}{l}.8293 \\
(1.17)\end{array}$ & $\begin{array}{l}.6806 \\
(0.99)\end{array}$ & $\begin{array}{l}-1.119 \\
(0.75)\end{array}$ & $\begin{array}{l}-1.675 \\
(1.97)^{* *}\end{array}$ & $\begin{array}{l}-1.996 \\
(1.57)\end{array}$ & $\begin{array}{l}-.9768 \\
(0.76)\end{array}$ & $\begin{array}{l}-1.653 \\
(1.77)^{*}\end{array}$ & $\begin{array}{l}-1.501 \\
(1.35)\end{array}$ \\
\hline Capital regulation index & $\begin{array}{l}.1123 \\
(1.65)^{*}\end{array}$ & $\begin{array}{l}.0192 \\
(0.20)\end{array}$ & $\begin{array}{l}.1408 \\
(2.52)^{* *}\end{array}$ & $\begin{array}{l}-.1577 \\
(1.07)\end{array}$ & $\begin{array}{l}-.0036 \\
(0.03)\end{array}$ & $\begin{array}{l}-.3610 \\
(3.69)^{* * *}\end{array}$ & $\begin{array}{l}-.1599 \\
(1.54)\end{array}$ & $\begin{array}{l}-.0089 \\
(0.08)\end{array}$ & $\begin{array}{l}-.2867 \\
(3.36)^{* * *}\end{array}$ \\
\hline Supervisory index & $\begin{array}{l}-.0332 \\
(0.53)\end{array}$ & $\begin{array}{l}.0078 \\
(0.05)\end{array}$ & $\begin{array}{l}-.1586 \\
(2.47)^{* *}\end{array}$ & $\begin{array}{l}.0171 \\
(0.22)\end{array}$ & $\begin{array}{l}.3458 \\
(2.28)^{* * *}\end{array}$ & $\begin{array}{l}.0674 \\
(1.17)\end{array}$ & $\begin{array}{l}-.0364 \\
(0.49)\end{array}$ & $\begin{array}{l}.0979 \\
(0.54)\end{array}$ & $\begin{array}{l}.0468 \\
(0.80)\end{array}$ \\
\hline Disclosure-insurance index & $\begin{array}{l}.0909 \\
(0.35)\end{array}$ & $\begin{array}{l}-.1289 \\
(0.91)\end{array}$ & $\begin{array}{l}.0557 \\
(0.35)\end{array}$ & $\begin{array}{l}.0051 \\
(0.01)\end{array}$ & $\begin{array}{l}.1602 \\
(1.24)\end{array}$ & $\begin{array}{l}.1098 \\
(0.50)\end{array}$ & $\begin{array}{l}.1625 \\
(0.55)\end{array}$ & $\begin{array}{l}-.0209 \\
(0.23)\end{array}$ & $\begin{array}{l}.1030 \\
(0.52)\end{array}$ \\
\hline Country dummies & Yes & Yes & Yes & Yes & Yes & Yes & Yes & Yes & Yes \\
\hline Year dummies & Yes & Yes & Yes & Yes & Yes & Yes & Yes & Yes & Yes \\
\hline Number of clusters & 40 & 28 & 31 & 40 & 28 & 31 & 40 & 28 & 31 \\
\hline Observations & 2048 & 1762 & 1966 & 2048 & 1762 & 1966 & 2048 & 1761 & 1965 \\
\hline Test of endogeneity(p-value) & 0.0000 & 0.0000 & 0.0000 & 0.0000 & 0.0000 & 0.0000 & 0.0000 & 0.0000 & 0.0000 \\
\hline Partial R2 of instruments & 0.0689 & 0.0728 & 0.0661 & 0.0689 & 0.0728 & 0.0661 & 0.0689 & 0.0728 & 0.0661 \\
\hline F-test of instruments (p-value) & 0.0000 & 0.0000 & 0.0000 & 0.0000 & 0.0000 & 0.0000 & 0.0000 & 0.0000 & 0.0000 \\
\hline Hansen J test (p-value) & 0.6128 & 0.1498 & 0.5730 & 0.2112 & 0.7820 & 0.1699 & 0.1181 & 0.6528 & 0.1687 \\
\hline Row1 + Row2 = 0 (p-value) & 0.6727 & 0.8375 & 0.8656 & 0.2885 & 0.9203 & 0.9531 & 0.2029 & 0.8609 & 0.7957 \\
\hline
\end{tabular}




\section{Table XV: Impact on Risk Taking for Banking Firms That First Issue Subordinated Debt}

The table reports bias-corrected nearest neighbor matching estimates of the average effect on risk taking for banking firms that first have raw subordinated debt changed from zero to positive during the period 2003-2007. The control group for a particular year includes banking firms that have not had subordinated debt on their balance sheets up to that year. Panel A shows estimates of the average treatment effect on treated banks one year after the treatment. Panel B reports estimates of the average treatment effect on treated banks one year before the treatment. Treated and control banks are matched by country, year, bank size, demand deposits ratio, loan growth, loan loss provisions ratio, liquidity ratio, independence dummy, capital-toassets ratio and average tax rate in the year before the treatment (Panel A), and two years before the treatment (Panel B). Columns (1), (4), and (7) report the results for the High subsample on Disclosure-insurance index (High DI); Columns (2), (5), and (8) report the results for the High subsample on Supervisory power index (High SP); and Columns (3), (6), and (9) report the results for the High subsample on Economic development (High ED). The outcome variable is z-score in Columns (1)-(3), standard deviation of return in Columns (4)-(6), and earnings volatility in Columns (7)-(8). z- statistics are reported in parentheses. *, **, and *** indicate significance at the $10 \%, 5 \%$, and $1 \%$ levels, respectively.

\section{Panel A: One year after the treatment}

\begin{tabular}{|c|c|c|c|c|c|c|c|c|c|}
\hline \multirow{2}{*}{$\begin{array}{l}\text { Outcome variable: } \\
\text { Number of matching banks }\end{array}$} & \multicolumn{3}{|c|}{ Z-score } & \multicolumn{3}{|c|}{ Standard deviation of return } & \multicolumn{3}{|c|}{ Earnings volatility } \\
\hline & High DI & High SP & High ED & High DI & High SP & High ED & High DI & High SP & High ED \\
\hline \multirow{3}{*}{1} & $(1)$ & $(2)$ & $(3)$ & $(4)$ & $(5)$ & $(6)$ & $(7)$ & $(8)$ & $(9)$ \\
\hline & 0.2788 & 0.2758 & 0.2990 & -0.1300 & -0.1121 & -0.1441 & -0.0879 & -0.0121 & -0.0849 \\
\hline & $(2.09)^{* *}$ & $(1.86)^{*}$ & $(2.26)^{* *}$ & $(3.03)^{* * *}$ & $(2.45)^{* *}$ & $(3.54)^{* * *}$ & $(1.81)^{*}$ & $(0.19)$ & $(1.99)^{* *}$ \\
\hline \multirow[t]{2}{*}{2} & 0.2133 & 0.1581 & 0.2143 & -0.1023 & -0.0747 & -0.1096 & -0.0564 & -0.0143 & -0.0656 \\
\hline & $(1.86)^{*}$ & $(1.27)$ & $(1.86)^{*}$ & $(2.90)^{* * *}$ & $(1.99) * *$ & $(3.23)^{* * *}$ & $(1.44)$ & $(0.28)$ & $(1.84)^{*}$ \\
\hline 3 & $\begin{array}{c}0.1648 \\
(1.54)\end{array}$ & $\begin{array}{c}0.1024 \\
(0.91)\end{array}$ & $\begin{array}{c}0.1685 \\
(1.56)\end{array}$ & $\begin{array}{c}-0.0940 \\
(2.87)^{* * *}\end{array}$ & $\begin{array}{c}-0.0578 \\
(1.67)^{*}\end{array}$ & $\begin{array}{c}-0.0988 \\
(3.10)^{* * *}\end{array}$ & $\begin{array}{c}-0.0458 \\
(1.22)\end{array}$ & $\begin{array}{c}-0.0080 \\
(0.16)\end{array}$ & $\begin{array}{c}-0.0558 \\
(1.62)\end{array}$ \\
\hline Number of observations & 1726 & 1720 & 1713 & 1726 & 1720 & 1713 & 1726 & 1720 & 1713 \\
\hline Number of treated banks & 276 & 273 & 273 & 276 & 273 & 273 & 276 & 273 & 273 \\
\hline
\end{tabular}




\section{Panel B: One year before the treatment}

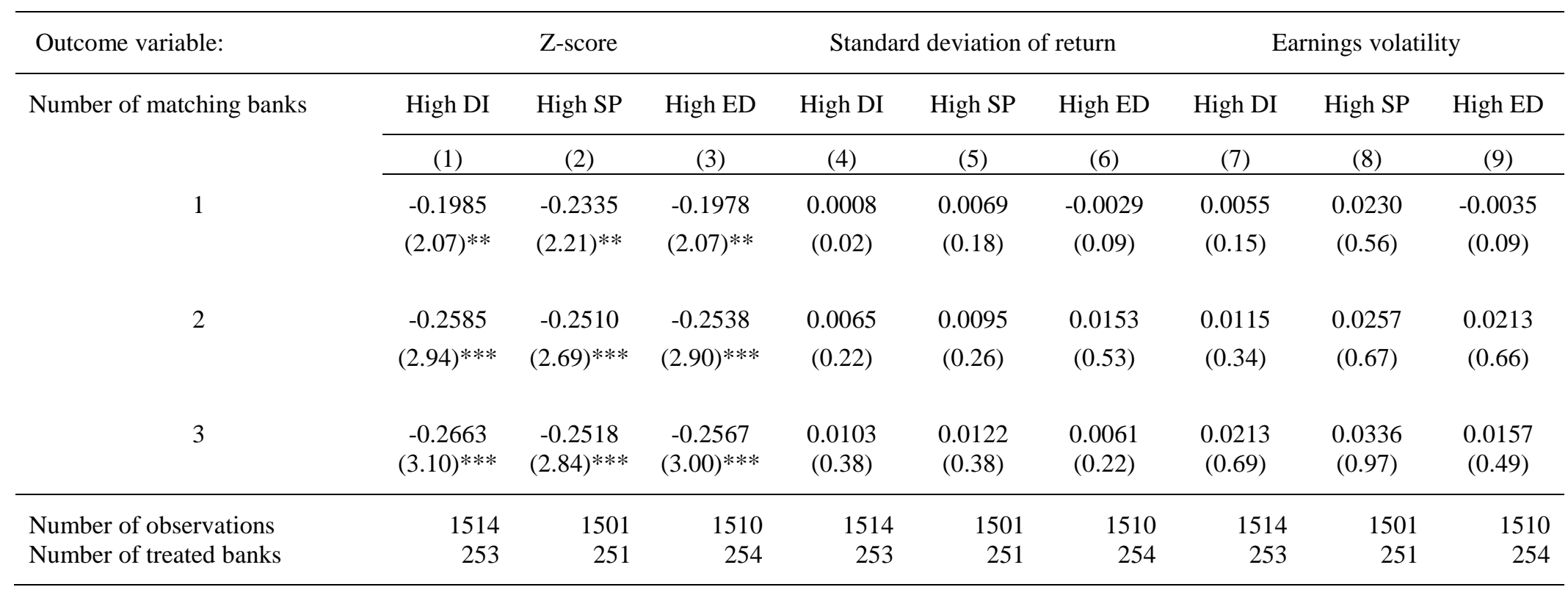




\section{APPENDIX B}

\section{SUPPLEMENTAL TABLES}

Table A: Distribution of Subordinated Debt Issuers

Panel A: Distribution of subordinated debt issuers over time

\begin{tabular}{rrrr}
\hline & & \multicolumn{2}{c}{ SND/TL, \% } \\
\cline { 3 - 4 } Year & No. obs. & Mean & Median \\
\hline 2002 & 143 & 2.06 & 1.78 \\
2003 & 179 & 2.11 & 1.78 \\
2004 & 214 & 2.15 & 1.85 \\
2005 & 485 & 2.29 & 2.09 \\
2006 & 604 & 2.34 & 2.16 \\
2007 & 521 & 2.29 & 2.15 \\
\hline
\end{tabular}

Panel B: Distribution of subordinated debt issuers across countries over 2002-2007

\begin{tabular}{lrrrr}
\hline & & & \multicolumn{2}{c}{ SND/TL, $\%$} \\
\cline { 3 - 5 } Country & No. banks & No. obs. & Mean & Median \\
\hline ARGENTINA & 6 & 20 & 2.78 & 2.98 \\
AUSTRALIA & 7 & 7 & 2.14 & 2.11 \\
AUSTRIA & 6 & 20 & 2.96 & 3.41 \\
BAHRAIN & 3 & 8 & 2.49 & 1.99 \\
BELGIUM & 4 & 8 & 1.58 & 1.68 \\
BOSNIA-HERZEGOVINA & 1 & 4 & 1.61 & 1.46 \\
BRAZIL & 11 & 42 & 3.40 & 3.50 \\
BULGARIA & 1 & 3 & 2.05 & 1.86 \\
CANADA & 9 & 54 & 1.58 & 1.48 \\
CHINA-PEOPLE'S REP. & 11 & 34 & 1.01 & 1.05 \\
CROATIA & 3 & 9 & 0.89 & 1.09 \\
CYPRUS & 3 & 15 & 2.61 & 2.70 \\
CZECH REPUBLIC & 2 & 6 & 0.91 & 0.94 \\
DENMARK & 35 & 116 & 3.69 & 3.27 \\
EL SALVADOR & 4 & 11 & 1.08 & 1.14 \\
ESTONIA & 3 & 14 & 2.21 & 2.51 \\
FINLAND & 1 & 2 & 3.13 & 3.13 \\
FRANCE & 6 & 9 & 1.26 & 1.13 \\
GERMANY & 14 & 56 & 1.50 & 1.57
\end{tabular}




\begin{tabular}{|c|c|c|c|c|}
\hline GREECE & 9 & 17 & 2.10 & 2.17 \\
\hline HONG KONG & 9 & 16 & 3.31 & 3.39 \\
\hline HUNGARY & 1 & 5 & 1.30 & 0.62 \\
\hline ICELAND & 3 & 3 & 3.03 & 3.20 \\
\hline INDIA & 1 & 2 & 2.31 & 2.31 \\
\hline INDONESIA & 14 & 53 & 2.06 & 1.69 \\
\hline IRELAND & 5 & 8 & 1.95 & 2.19 \\
\hline ISRAEL & 6 & 34 & 3.83 & 3.64 \\
\hline ITALY & 11 & 16 & 2.10 & 2.04 \\
\hline JAPAN & 13 & 41 & 0.28 & 0.24 \\
\hline JORDAN & 1 & 2 & 1.48 & 1.48 \\
\hline KAZAKHSTAN & 10 & 40 & 3.98 & 3.89 \\
\hline KOREA REP. OF & 11 & 50 & 2.36 & 2.41 \\
\hline KUWAIT & 2 & 6 & 1.42 & 1.40 \\
\hline LATVIA & 3 & 6 & 2.00 & 1.94 \\
\hline LITHUANIA & 4 & 19 & 1.82 & 2.02 \\
\hline LUXEMBOURG & 3 & 3 & 3.11 & 2.97 \\
\hline MACEDONIA (FYROM) & 2 & 2 & 2.22 & 2.22 \\
\hline MALAYSIA & 11 & 35 & 1.85 & 1.83 \\
\hline MALTA & 3 & 13 & 1.49 & 1.37 \\
\hline MEXICO & 4 & 14 & 1.88 & 1.40 \\
\hline NETHERLANDS & 5 & 11 & 2.48 & 1.36 \\
\hline NORWAY & 2 & 2 & 2.31 & 2.31 \\
\hline OMAN & 3 & 16 & 2.12 & 1.67 \\
\hline PAKISTAN & 2 & 2 & 1.70 & 1.70 \\
\hline PANAMA & 1 & 2 & 0.95 & 0.95 \\
\hline PERU & 2 & 6 & 1.48 & 1.38 \\
\hline PHILIPPINES & 6 & 12 & 2.75 & 2.82 \\
\hline POLAND & 3 & 8 & 2.63 & 2.52 \\
\hline PORTUGAL & 7 & 10 & 2.89 & 2.81 \\
\hline QATAR & 1 & 1 & 1.30 & 1.30 \\
\hline ROMANIA & 2 & 4 & 2.32 & 2.31 \\
\hline RUSSIAN FEDERATION & 21 & 57 & 2.53 & 2.60 \\
\hline SAUDI ARABIA & 2 & 4 & 2.02 & 1.94 \\
\hline SINGAPORE & 4 & 7 & 3.55 & 3.63 \\
\hline SLOVAKIA & 1 & 1 & 1.07 & 1.07 \\
\hline SLOVENIA & 4 & 16 & 1.56 & 1.45 \\
\hline SOUTH AFRICA & 6 & 9 & 1.95 & 1.87 \\
\hline SPAIN & 8 & 16 & 2.14 & 2.19 \\
\hline SRI LANKA & 6 & 30 & 2.84 & 2.78 \\
\hline SWEDEN & 3 & 6 & 2.06 & 1.99 \\
\hline SWITZERLAND & 3 & 11 & 0.96 & 0.84 \\
\hline TAIWAN & 11 & 15 & 2.58 & 3.02 \\
\hline
\end{tabular}




\begin{tabular}{lrrrr} 
THAILAND & 1 & 1 & 0.38 & 0.38 \\
TUNISIA & 1 & 1 & 2.04 & 2.04 \\
TURKEY & 5 & 14 & 1.13 & 1.08 \\
UKRAINE & 8 & 21 & 2.21 & 1.91 \\
UNITED ARAB EMIRATES & 4 & 6 & 2.25 & 2.23 \\
UNITED KINGDOM & 8 & 14 & 2.66 & 2.60 \\
USA & 338 & 1012 & 2.19 & 2.09 \\
VENEZUELA & 2 & 5 & 0.84 & 0.87 \\
ZAMBIA & 1 & 3 & 1.34 & 1.30 \\
\hline Total & 727 & 2146 & &
\end{tabular}


Table B: Distribution of Subordinated Debt First Issuances

Panel A: Distribution of first issuances over time

\begin{tabular}{crrrr}
\hline & \multicolumn{2}{c}{$2003-2007$} & \multicolumn{2}{c}{ 2003-2007 matching sample } \\
\cline { 2 - 5 } Year & All countries & \multicolumn{1}{c}{ The USA } & All countries & The USA \\
\hline 2003 & 28 & 16 & 15 & 9 \\
2004 & 38 & 19 & 16 & 11 \\
2005 & 318 & 298 & 224 & 217 \\
2006 & 31 & 16 & 21 & 12 \\
2007 & 19 & 10 & 10 & 7 \\
\hline Total & 434 & 359 & 286 & 256 \\
\hline
\end{tabular}

Panel B: Distribution of first issuances across countries over 2003-2007

\begin{tabular}{lrr}
\hline Country & 2003-2007 & 2 \\
\hline BOSNIA-HERZEGOVINA & 3 & 3 \\
BRAZIL & 4 & \\
CHINA-PEOPLE'S REP. & 5 & 4 \\
COLOMBIA & 1 & \\
DENMARK & 5 & \\
EGYPT & 1 & \\
EL SALVADOR & 1 & \\
GEORGIA REP. OF & 1 & \\
GREECE & 1 & \\
HONG KONG & 1 & \\
INDIA & 5 & \\
ISRAEL & 1 & \\
JAPAN & 3 & \\
KAZAKHSTAN & 4 & \\
KENYA & 1 & \\
KOREA REP. OF & 2 & \\
KUWAIT & 2 & \\
KYRGYZSTAN & 1 & \\
MALAYSIA & 3 & \\
MAURITIUS & 1 & \\
OMAN & 1 & \\
PAKISTAN & 3 & \\
QATAR & 1 & \\
ROMANIA & 1 & \\
RUSSIAN FEDERATION & 6 &
\end{tabular}




\begin{tabular}{lrr} 
SAUDI ARABIA & 1 & 1 \\
SLOVAKIA & 1 & \\
SRI LANKA & 2 & \\
TAIWAN & 4 & 1 \\
TURKEY & 1 & 2 \\
UKRAINE & 3 & 3 \\
UNITED ARAB EMIRATES & 3 & 256 \\
USA & 359 & 1 \\
VENEZUELA & 1 & 1 \\
ZAMBIA & 1 & 286 \\
\hline Total & 434 & \\
\hline
\end{tabular}




\section{Table C: Robustness Check for Banks with Unconsolidated Financial Statements}

Regressions in Panel A include a dummy for banks with unconsolidated accounts. Regressions in Panel B include a dummy for banks with unconsolidated accounts and positive SND ratio and an interaction term between this dummy and the SND ratio. Dependent variable is z-score in Columns (1)-(3), standard deviation of return in Columns (4)-(6), and earnings volatility in Columns (7)-(9). Regressors are lagged by one year. All regressions are estimated using 2SLS, where Columns (1), (4) and (7) report the results for the High subsample on Disclosure-insurance index (High DI); Columns (2), (5) and (8) report the results for the High subsample on Supervisory power index (High SP); and Columns (3), (6) and (9) report the results for the High subsample on Economic development (High ED). The IVs for SND/RWA are the average SND ratio of other banks in the same country, year, and size group, the lagged capital-to-assets ratio, and the average tax rate. In Panel B, the IVs for the interaction term between the SND ratio and the unconsolidated dummy are the interaction terms between the unconsolidated dummy and each of the three variables: the average SND ratio of other banks in the same country, year and size group, the bank's lagged capital-to-assets ratio, and the bank's average tax rate. See Table I for variable definition. Also included are the p-value of the regression-based test of endogeneity, the partial R 2 of excluded instruments in the first-stage estimation of SND/RWA, the p-value of the F-test of excluded instruments in the first-stage estimation of SND/RWA, and the p-value of the Hansen J test of overidentification. Also reported at the bottom of Panel B is the p-value of the test of the null hypothesis that the sum of the coefficients on the SND ratio and on the interaction term between the SND ratio and the unconsolidated dummy is zero. Standard errors are clustered at the country level. Z-statistics are reported in parentheses. $*, * *$, and $* * *$ indicate significance at the $10 \%, 5 \%$, and $1 \%$ levels, respectively.

Panel A: The Unconsolidated dummy is an indicator variable that takes value 1 for banks with unconsolidated accounts

\begin{tabular}{|c|c|c|c|c|c|c|c|c|c|}
\hline \multirow[t]{2}{*}{ Dependent variable: } & \multicolumn{3}{|c|}{ Z-score } & \multicolumn{3}{|c|}{ Standard deviation of return } & \multicolumn{3}{|c|}{ Earnings volatility } \\
\hline & High DI & High SP & High ED & High DI & High SP & High ED & High DI & High SP & High ED \\
\hline & $(1)$ & (2) & (3) & (4) & (5) & (6) & (7) & $(8)$ & (9) \\
\hline SND/RWA & $\begin{array}{l}.2030 \\
(2.57)^{* *}\end{array}$ & $\begin{array}{l}.2719 \\
(9.98)^{* * *}\end{array}$ & $\begin{array}{l}.2814 \\
(3.19)^{* * * *}\end{array}$ & $\begin{array}{l}-1.055 \\
(3.97)^{* * *}\end{array}$ & $\begin{array}{l}-1.253 \\
(15.23)^{* * *}\end{array}$ & $\begin{array}{l}-1.148 \\
(4.65)^{* * *}\end{array}$ & $\begin{array}{l}-.9251 \\
(4.38)^{* * *}\end{array}$ & $\begin{array}{l}-1.058 \\
(16.84)^{* * *}\end{array}$ & $\begin{array}{l}-1.027 \\
(5.81)^{* * *}\end{array}$ \\
\hline Loan growth & $\begin{array}{l}-.0113 \\
(8.16)^{* * *}\end{array}$ & $\begin{array}{l}-.0105 \\
(5.83)^{* * *}\end{array}$ & $\begin{array}{l}-.0119 \\
(11.87)^{* * * *}\end{array}$ & $\begin{array}{l}.0152 \\
(4.42)^{* * * *}\end{array}$ & $\begin{array}{l}.0156 \\
(4.90)^{* * * *}\end{array}$ & $\begin{array}{l}.0162 \\
(6.27)^{* * *}\end{array}$ & $\begin{array}{l}.0146 \\
(5.14)^{* * * *}\end{array}$ & $\begin{array}{l}.0146 \\
(5.60)^{* * * *}\end{array}$ & $\begin{array}{l}.0155 \\
(7.47)^{* * * *}\end{array}$ \\
\hline Size & $\begin{array}{l}-.0038 \\
(0.25)\end{array}$ & $\begin{array}{l}-.0121 \\
(1.12)\end{array}$ & $\begin{array}{l}-.0270 \\
(1.86)^{*}\end{array}$ & $\begin{array}{l}.2437 \\
(2.46)^{* *}\end{array}$ & $\begin{array}{l}.3264 \\
(10.45)^{* * *}\end{array}$ & $\begin{array}{l}.2645 \\
(2.73)^{* * *}\end{array}$ & $\begin{array}{l}.2016 \\
(2.41)^{* *}\end{array}$ & $\begin{array}{l}.2657 \\
(11.14)^{* * *}\end{array}$ & $\begin{array}{l}.2256 \\
(2.91)^{* * * *}\end{array}$ \\
\hline Demand deposits ratio & $\begin{array}{l}.0023 \\
(0.80)\end{array}$ & $\begin{array}{l}.0066 \\
(3.12)^{* * *}\end{array}$ & $\begin{array}{l}.0012 \\
(0.29)\end{array}$ & $\begin{array}{l}.0012 \\
(0.54)\end{array}$ & $\begin{array}{l}-.0023 \\
(0.66)\end{array}$ & $\begin{array}{l}.0002 \\
(0.13)\end{array}$ & $\begin{array}{l}.0010 \\
(0.52)\end{array}$ & $\begin{array}{l}-.0020 \\
(0.74)\end{array}$ & $\begin{array}{l}.0003 \\
(0.15)\end{array}$ \\
\hline Independence dummy & $\begin{array}{l}.0181 \\
(0.45)\end{array}$ & $\begin{array}{l}.0826 \\
(1.63)\end{array}$ & $\begin{array}{l}.0080 \\
(0.17)\end{array}$ & $\begin{array}{l}.0122 \\
(0.11)\end{array}$ & $\begin{array}{l}-.1158 \\
(2.06)^{* *}\end{array}$ & $\begin{array}{l}-.0092 \\
(0.07)\end{array}$ & $\begin{array}{l}.0596 \\
(0.54)\end{array}$ & $\begin{array}{l}-.0377 \\
(0.60)\end{array}$ & $\begin{array}{l}.0290 \\
(0.25)\end{array}$ \\
\hline Loan loss provisions ratio & $\begin{array}{l}-.0219 \\
(3.18)^{* * *}\end{array}$ & $\begin{array}{l}-.0217 \\
(2.87)^{* * *}\end{array}$ & $\begin{array}{l}-.0300 \\
(3.85)^{* * * *}\end{array}$ & $\begin{array}{l}.0160 \\
(2.74)^{* * *}\end{array}$ & $\begin{array}{l}.0150 \\
(2.66)^{* * * *}\end{array}$ & $\begin{array}{l}.0241 \\
(4.50)^{* * *}\end{array}$ & $\begin{array}{l}.0110 \\
(1.80)^{*}\end{array}$ & $\begin{array}{l}.0103 \\
(1.81)^{*}\end{array}$ & $\begin{array}{l}.0199 \\
(4.06)^{* * *}\end{array}$ \\
\hline Liquidity ratio & $\begin{array}{l}-.0071 \\
(1.62)\end{array}$ & $\begin{array}{l}-.0125 \\
(5.48)^{* * *}\end{array}$ & $\begin{array}{l}-.0076 \\
(1.72)^{*}\end{array}$ & $\begin{array}{l}.0099 \\
(1.66)^{*}\end{array}$ & $\begin{array}{l}.0160 \\
(3.60)^{* * *}\end{array}$ & $\begin{array}{l}.0118 \\
(2.06)^{* *}\end{array}$ & $\begin{array}{l}.0139 \\
(1.76)^{*}\end{array}$ & $\begin{array}{l}.0234 \\
(5.08)^{* * * *}\end{array}$ & $\begin{array}{l}.0153 \\
(1.97)^{* *}\end{array}$ \\
\hline Unconsolidated dummy & $\begin{array}{l}-.1145 \\
(1.89)^{*}\end{array}$ & $\begin{array}{l}-.0585 \\
(2.41)^{* *}\end{array}$ & $\begin{array}{l}-.0767 \\
(1.08)\end{array}$ & $\begin{array}{l}-.3283 \\
(1.46)\end{array}$ & $\begin{array}{l}-.4926 \\
(4.77)^{* * * *}\end{array}$ & $\begin{array}{l}-.4166 \\
(1.95)^{*}\end{array}$ & $\begin{array}{l}-.3173 \\
(1.67)^{*}\end{array}$ & $\begin{array}{l}-.4494 \\
(5.47)^{* * * *}\end{array}$ & $\begin{array}{l}-.3955 \\
(2.20)^{* *}\end{array}$ \\
\hline GDP per capita & $\begin{array}{l}.4605 \\
(0.54)\end{array}$ & $\begin{array}{l}.6814 \\
(1.05)\end{array}$ & $\begin{array}{l}.4706 \\
(0.75)\end{array}$ & $\begin{array}{l}-.6673 \\
(0.42)\end{array}$ & $\begin{array}{l}-1.615 \\
(1.51)\end{array}$ & $\begin{array}{l}-1.767 \\
(1.25)\end{array}$ & $\begin{array}{l}-.6862 \\
(0.50)\end{array}$ & $\begin{array}{l}-1.601 \\
(1.41)\end{array}$ & $\begin{array}{l}-1.389 \\
(1.12)\end{array}$ \\
\hline
\end{tabular}




\begin{tabular}{|c|c|c|c|c|c|c|c|c|c|}
\hline Capital regulation index & $\begin{array}{l}.0933 \\
(1.27)\end{array}$ & $\begin{array}{l}-.0376 \\
(0.41)\end{array}$ & $\begin{array}{l}.1277 \\
(2.15)^{* *}\end{array}$ & $\begin{array}{l}-.1272 \\
(0.80)\end{array}$ & $\begin{array}{l}.2401 \\
(1.89)^{*}\end{array}$ & $\begin{array}{l}-.3425 \\
(3.49)^{* * *}\end{array}$ & $\begin{array}{l}-.1381 \\
(1.22)\end{array}$ & $\begin{array}{l}.2063 \\
(1.67)^{*}\end{array}$ & $\begin{array}{l}-.2776 \\
(3.29)^{* * *}\end{array}$ \\
\hline \multirow[t]{2}{*}{ Supervisory index } & -.0052 & .0745 & -.1179 & -.0354 & .0872 & -.0746 & -.0701 & -.0982 & -.0622 \\
\hline & $(0.09)$ & $(0.55)$ & $(1.63)$ & $(0.33)$ & $(0.22)$ & $(0.55)$ & $(0.77)$ & $(0.26)$ & $(0.54)$ \\
\hline \multirow[t]{2}{*}{ Disclosure-insurance index } & -.0189 & -.2679 & -.0397 & .1886 & .8687 & .4413 & .2757 & .5420 & .3509 \\
\hline & $(0.08)$ & $(2.85) * * *$ & $(0.22)$ & $(0.53)$ & $(3.27)^{* * *}$ & $(1.20)$ & $(1.00)$ & $(2.26)^{* *}$ & $(1.15)$ \\
\hline Country dummies & Yes & Yes & Yes & Yes & Yes & Yes & Yes & Yes & Yes \\
\hline Year dummies & Yes & Yes & Yes & Yes & Yes & Yes & Yes & Yes & Yes \\
\hline Number of clusters & 40 & 28 & 31 & 40 & 28 & 31 & 40 & 28 & 31 \\
\hline Observations & 2048 & 1762 & 1966 & 2048 & 1762 & 1966 & 2048 & 1761 & 1965 \\
\hline Test of endogeneity(p-value) & 0.0000 & 0.0000 & 0.0000 & 0.0000 & 0.0000 & 0.0000 & 0.0000 & 0.0000 & 0.0000 \\
\hline Partial R2 of instruments & 0.0577 & 0.0569 & 0.0551 & 0.0577 & 0.0569 & 0.0551 & 0.0577 & 0.0569 & 0.0550 \\
\hline F-test of instruments (p-value) & 0.0000 & 0.0000 & 0.0000 & 0.0000 & 0.0000 & 0.0000 & 0.0000 & 0.0000 & 0.0000 \\
\hline Hansen $J$ test (p-value) & 0.5497 & 0.5078 & 0.5327 & 0.0349 & 0.1812 & 0.0554 & 0.0216 & 0.1621 & 0.0694 \\
\hline
\end{tabular}


Panel B: The Unconsolidated dummy is an indicator variable that takes value 1 for banks with unconsolidated accounts and positive subordinated debt ratio

\begin{tabular}{|c|c|c|c|c|c|c|c|c|c|}
\hline \multirow[t]{2}{*}{ Dependent variable: } & \multicolumn{3}{|c|}{ Z-score } & \multicolumn{3}{|c|}{ Standard deviation of return } & \multicolumn{3}{|c|}{ Earnings volatility } \\
\hline & High DI & High SP & High ED & High DI & High SP & High ED & High DI & High SP & High ED \\
\hline & $(1)$ & $(2)$ & (3) & $(4)$ & $(5)$ & $(6)$ & $(7)$ & $(8)$ & $(9)$ \\
\hline SND/RWA & $\begin{array}{l}.2383 \\
(3.97)^{* * *}\end{array}$ & $\begin{array}{l}.2671 \\
(6.92)^{* * *}\end{array}$ & $\begin{array}{l}.2851 \\
(4.51)^{* * *}\end{array}$ & $\begin{array}{l}-.9806 \\
(4.43) * * *\end{array}$ & $\begin{array}{l}-1.072 \\
(18.95)^{* * *}\end{array}$ & $\begin{array}{l}-1.030 \\
(5.13)^{* * *}\end{array}$ & $\begin{array}{l}-.8564 \\
(4.84)^{* * *}\end{array}$ & $\begin{array}{l}-.8730 \\
(13.72)^{* * *}\end{array}$ & $\begin{array}{l}-.9158 \\
(6.04)^{* * *}\end{array}$ \\
\hline SND/RWA * Unconsolidated dummy & $\begin{array}{l}-.0157 \\
(0.13)\end{array}$ & $\begin{array}{l}.1720 \\
(0.76)\end{array}$ & $\begin{array}{l}-.2478 \\
(2.88) * * *\end{array}$ & $\begin{array}{l}.2165 \\
(1.00)\end{array}$ & $\begin{array}{l}.0744 \\
(0.31)\end{array}$ & $\begin{array}{l}.4905 \\
(4.69)^{* * *}\end{array}$ & $\begin{array}{l}.1881 \\
(1.33)\end{array}$ & $\begin{array}{l}.1924 \\
(1.12)\end{array}$ & $\begin{array}{l}.4047 \\
(3.33)^{* * * *}\end{array}$ \\
\hline Loan growth & $\begin{array}{l}-.0118 \\
(9.68)^{* * *}\end{array}$ & $\begin{array}{l}-.0107 \\
(6.34)^{* * *}\end{array}$ & $\begin{array}{l}-.0118 \\
(13.13)^{* * *}\end{array}$ & $\begin{array}{l}.0134 \\
(4.83)^{* * *}\end{array}$ & $\begin{array}{l}.0133 \\
(5.29)^{* * *}\end{array}$ & $\begin{array}{l}.0133 \\
(5.86) * * *\end{array}$ & $\begin{array}{l}.0129 \\
(5.73)^{* * *}\end{array}$ & $\begin{array}{l}.0123 \\
(5.70)^{* * * *}\end{array}$ & $\begin{array}{l}.01284 \\
(6.99)^{* * * *}\end{array}$ \\
\hline Size & $\begin{array}{l}-.0024 \\
(0.16)\end{array}$ & $\begin{array}{l}-.0028 \\
(0.19)\end{array}$ & $\begin{array}{l}-.0231 \\
(1.95)^{*}\end{array}$ & $\begin{array}{l}.2689 \\
(2.76)^{* * *}\end{array}$ & $\begin{array}{l}.3213 \\
(10.16)^{* * *}\end{array}$ & $\begin{array}{l}.2854 \\
(3.19)^{* * *}\end{array}$ & $\begin{array}{l}.2255 \\
(2.68)^{* * *}\end{array}$ & $\begin{array}{l}.2546 \\
(7.62)^{* * *}\end{array}$ & $\begin{array}{l}.2449 \\
(3.29)^{* * *}\end{array}$ \\
\hline Demand deposits ratio & $\begin{array}{l}.0020 \\
(0.66)\end{array}$ & $\begin{array}{l}.0062 \\
(2.82)^{* * * *}\end{array}$ & $\begin{array}{l}.0009 \\
(0.20)\end{array}$ & $\begin{array}{l}-.0005 \\
(0.18)\end{array}$ & $\begin{array}{l}-.0043 \\
(1.40)\end{array}$ & $\begin{array}{l}-.0014 \\
(0.61)\end{array}$ & $\begin{array}{l}-.0005 \\
(0.22)\end{array}$ & $\begin{array}{l}-.0035 \\
(1.52)\end{array}$ & $\begin{array}{l}-.001293 \\
(0.62)\end{array}$ \\
\hline Independence dummy & $\begin{array}{l}.0413 \\
(1.05)\end{array}$ & $\begin{array}{l}.0992 \\
(2.48)^{* *}\end{array}$ & $\begin{array}{l}.0465 \\
(1.11)\end{array}$ & $\begin{array}{l}.0895 \\
(1.95)^{*}\end{array}$ & $\begin{array}{l}.0410 \\
(1.26)\end{array}$ & $\begin{array}{l}.0654 \\
(2.56)^{* *}\end{array}$ & $\begin{array}{l}.1337 \\
(3.07) * * *\end{array}$ & $\begin{array}{l}.0894 \\
(2.91)^{* * * *}\end{array}$ & $\begin{array}{l}.1039 \\
(4.52)^{* * * *}\end{array}$ \\
\hline Loan loss provisions ratio & $\begin{array}{l}-.0221 \\
(3.22)^{* * *}\end{array}$ & $\begin{array}{l}-.0213 \\
(2.67)^{* * *}\end{array}$ & $\begin{array}{l}-.0303 \\
(4.10)^{* * *}\end{array}$ & $\begin{array}{l}.0154 \\
(2.90)^{* * *}\end{array}$ & $\begin{array}{l}.0146 \\
(2.73)^{* * *}\end{array}$ & $\begin{array}{l}.0239 \\
(5.89)^{* * *}\end{array}$ & $\begin{array}{l}.0105 \\
(1.85)^{*}\end{array}$ & $\begin{array}{l}.0102 \\
(1.97)^{* *}\end{array}$ & $\begin{array}{l}.01968 \\
(5.28)^{* * * *}\end{array}$ \\
\hline Liquidity ratio & $\begin{array}{l}-.0077 \\
(1.77)^{*}\end{array}$ & $\begin{array}{l}-.0127 \\
(5.52)^{* * *}\end{array}$ & $\begin{array}{l}-.0080 \\
(1.89)^{*}\end{array}$ & $\begin{array}{l}.0096 \\
(2.25)^{* *}\end{array}$ & $\begin{array}{l}.0133 \\
(3.96)^{* * *}\end{array}$ & $\begin{array}{l}.0111 \\
(3.15)^{* * *}\end{array}$ & $\begin{array}{l}.0135 \\
(2.12)^{* *}\end{array}$ & $\begin{array}{l}.0208 \\
(5.62)^{* * *}\end{array}$ & $\begin{array}{l}.01462 \\
(2.55)^{* *}\end{array}$ \\
\hline Unconsolidated dummy & $\begin{array}{l}-.0129 \\
(0.04)\end{array}$ & $\begin{array}{l}-.2857 \\
(0.52)\end{array}$ & $\begin{array}{l}.4666 \\
(2.11)^{* *}\end{array}$ & $\begin{array}{l}.2852 \\
(0.56)\end{array}$ & $\begin{array}{l}.3468 \\
(0.81)\end{array}$ & $\begin{array}{l}-.1731 \\
(0.77)\end{array}$ & $\begin{array}{l}.2128 \\
(0.61)\end{array}$ & $\begin{array}{l}-.0831 \\
(0.26)\end{array}$ & $\begin{array}{l}-.05521 \\
(0.20)\end{array}$ \\
\hline GDP per capita & $\begin{array}{l}.4649 \\
(0.54)\end{array}$ & $\begin{array}{l}.6594 \\
(1.00)\end{array}$ & $\begin{array}{l}.5428 \\
(0.83)\end{array}$ & $\begin{array}{l}-.7659 \\
(0.50)\end{array}$ & $\begin{array}{l}-1.471 \\
(1.54)\end{array}$ & $\begin{array}{l}-1.584 \\
(1.21)\end{array}$ & $\begin{array}{l}-.7741 \\
(0.58)\end{array}$ & $\begin{array}{l}-1.438 \\
(1.42)\end{array}$ & $\begin{array}{l}-1.209 \\
(1.05)\end{array}$ \\
\hline Capital regulation index & $\begin{array}{l}.0927 \\
(1.32)\end{array}$ & $\begin{array}{l}-.0460 \\
(0.48)\end{array}$ & $\begin{array}{l}.1064 \\
(1.89)^{*}\end{array}$ & $\begin{array}{l}-.1213 \\
(0.80)\end{array}$ & $\begin{array}{l}.2075 \\
(1.79)^{*}\end{array}$ & $\begin{array}{l}-.3192 \\
(3.61)^{* * *}\end{array}$ & $\begin{array}{l}-.1339 \\
(1.26)\end{array}$ & $\begin{array}{l}.1748 \\
(1.58)\end{array}$ & $\begin{array}{l}-.2601 \\
(3.36)^{* * *}\end{array}$ \\
\hline Supervisory index & $\begin{array}{l}-.0030 \\
(0.05)\end{array}$ & $\begin{array}{l}.0405 \\
(0.26)\end{array}$ & $\begin{array}{l}-.1155 \\
(1.62)\end{array}$ & $\begin{array}{l}-.0283 \\
(0.29)\end{array}$ & $\begin{array}{l}.0826 \\
(0.24)\end{array}$ & $\begin{array}{l}-.0687 \\
(0.58)\end{array}$ & $\begin{array}{l}-.0638 \\
(0.76)\end{array}$ & $\begin{array}{l}-.1194 \\
(0.38)\end{array}$ & $\begin{array}{l}-.05469 \\
(0.55)\end{array}$ \\
\hline Disclosure-insurance index & $\begin{array}{l}-.0184 \\
(0.08)\end{array}$ & $\begin{array}{l}-.2923 \\
(2.13)^{* *}\end{array}$ & $\begin{array}{l}-.0341 \\
(0.19)\end{array}$ & $\begin{array}{l}.1649 \\
(0.47)\end{array}$ & $\begin{array}{l}.7664 \\
(3.48)^{* * * *}\end{array}$ & $\begin{array}{l}.4161 \\
(1.24)\end{array}$ & $\begin{array}{l}.2562 \\
(0.95)\end{array}$ & $\begin{array}{l}.4174 \\
(2.21)^{* *}\end{array}$ & $\begin{array}{l}.3248 \\
(1.19)\end{array}$ \\
\hline Country dummies & Yes & Yes & Yes & Yes & Yes & Yes & Yes & Yes & Yes \\
\hline Year dummies & Yes & Yes & Yes & Yes & Yes & Yes & Yes & Yes & Yes \\
\hline Number of clusters & 40 & 28 & 31 & 40 & 28 & 31 & 40 & 28 & 31 \\
\hline Observations & 2048 & 1762 & 1966 & 2048 & 1762 & 1966 & 2048 & 1761 & 1965 \\
\hline Test of endogeneity(p-value) & 0.0000 & 0.0000 & 0.0000 & 0.0000 & 0.0000 & 0.0000 & 0.0000 & 0.0000 & 0.0000 \\
\hline Partial R2 of instruments & 0.0702 & 0.0739 & 0.0694 & 0.0702 & 0.0739 & 0.0694 & 0.0702 & 0.0738 & 0.0693 \\
\hline F-test of instruments (p-value) & 0.0000 & 0.0000 & 0.0000 & 0.0000 & 0.0000 & 0.0000 & 0.0000 & 0.0000 & 0.0000 \\
\hline Hansen J test (p-value) & 0.4515 & 0.7648 & 0.7815 & 0.0589 & 0.3572 & 0.2982 & 0.0488 & 0.2953 & 0.2849 \\
\hline Row $1+$ Row2 $=0(\mathrm{p}$-value $)$ & 0.1479 & 0.0787 & 0.7147 & 0.0190 & 0.0000 & 0.0020 & 0.0049 & 0.0002 & 0.0000 \\
\hline
\end{tabular}




\section{REFERENCES CITED}

Abadie, A., Imbens, G., 2002. Simple and bias-corrected matching estimators. Technical Report, University of California, Berkeley.

Abadie, A., Drukker, D., Herr, J.L., Imbens, G., 2004. Implementing matching estimators for average treatment effects in Stata. The Stata Journal 4, No. 3, 290-311.

Altman, E., Saunders, A., 1998. Credit Risk Measurement: Developments over the Last 20 Years. Journal of Banking and Finance 21, 1721-1742.

Ashcraft, A., 2006. Does the market discipline banks? New evidence from the regulatory capital mix. Federal Reserve Bank of New York Staff Reports, No. 244.

Admati, A.R., DeMarzo, P.M., Hellwig, M.F., Pfleiderer, P.C., 2010. Fallacies, Irrelevant Facts, and Myths in the Discussion of Capital Regulation: Why Bank Equity is not Expensive. Rock Center for Corporate Governance at Stanford University Working Paper No. 86.

Avery, R.B., Belton, T.M., Goldberg, M.A., 1988. Market discipline in regulating bank risk: new evidence from the capital markets. Journal of Money, Credit, and Banking 20, 597-610.

Barth, J.R, Caprio, G., Levine, R., 2001. The regulation and supervision of bank around the world: a new database. In: Litan, R.E., Herring, R. (Eds.), Integrating Emerging Market Countries into the Global Financial System, Brookings-Wharton Papers in Financial Services. Brooking Institution Press, pp. 183-240.

Barth, J.R., Caprio, G., Levine, R., 2004. Bank Supervision and Regulation: What Works Best? Journal of Financial Intermediation 13, 205-248.

Barth, J.R., Caprio, G., Levine, R., 2008. Bank Regulations are Changing: For Better or Worse? World Bank Policy Research Working Paper Series. Available at SSRN: http://ssrn.com/abstract=1149579.

Barth, J.R., Lin, C., Lin, P., Song, F.M., 2009. Corruption in bank lending to firms: Cross-country micro evidence on the beneficial role of competition and information sharing. Journal of Financial Economics 91, 361-388.

Basel Committee on Banking Supervision, 2001. The New Basel Capital Accord. Consultative Document.

Basel Committee on Banking Supervision, 2003. Markets for Bank Subordinated Debt and Equity in Basel Committee Member Countries. Working Paper No. 12. 
Beck, T., Demirguc-Kunt, A., Levine, R., 2006. Bank Supervision and Corruption in Lending. Journal of Monetary Economics 53, 2131-2163.

Berger, A., Davies, S., Flannery, M., 2000. Comparing market and supervisory assessments of bank performance: Who knows what when? Journal of Money, Credit and Banking 32, 641-667.

Black, F., Cox, J.C., 1976. Valuing Corporate Securities: Some Effects of Bond Indenture Provisions. Journal of Finance 31, 351-367.

Bliss, R., Flannery, M., 2000. Market discipline in the governance of U.S. bank holding companies: Monitoring vs. influencing. Europe Finance Review 6, 361-395.

Blum, J., 2002. Subordinated debt, market discipline, and banks' risk taking. Journal of Banking and Finance 26, 1427-1441.

Calomiris, C.W., 1999. Building an incentive-compatible safety net. Journal of Banking and Finance 23, 1499-1519.

Cameron, A.C., Gelbach, J., Douglas, M., 2006. Robust Inference with Multi-way Clustering. NBER Technical Working Paper No. 327.

Caprio, G., Laeven, L., Levine R., 2007. Ownership and Bank Valuation. Journal of Financial Intermediation 16, 584-617.

David, H.A., Hartley, H.O., Pearson E.S., 1954. The Distribution of the Ratio, in a Single Normal Sample, of Range to Standard Deviation. Biometrika 61.

Decamps, J., Rochet, J.-C., Roger, B., 2004. The three pillars of Basel II: Optimizing the mix. Journal of Financial Intermediation 13, 132-155.

Dell'Ariccia, G., Detragiache, E., Rajan, R., 2008. The real effects of banking crises. Journal of Financial Intermediation 17, 89-112.

Demirguc-Kunt, A., Laeven, L., Levine, R., 2004. Regulations, Market Structure, Institutions, and the Cost of Financial Intermediation. Journal of Money, Credit and Banking 36, 593-622.

Demsetz, H., Lehn, K., 1985. The structure of corporate ownership: causes and consequences. Journal of Political Economy 93, 1155-1177.

De Nicoló, G., 2000. Size, Charter Value and Risk in Banking: an International Perspective. Federal Reserve International Finance Discussion Paper No. 689. 
DeYoung, R., Flannery, M.J., Lang, W.W., Sorescu, S., 1998. The Informational Advantage of Specialized Monitors: The Case of Bank Examiners. Federal Reserve Bank of Chicago Working Paper Series, No. 98-4.

DeYoung, R., Flannery, M.J., Lang, W.W., Sorescu, S., 2001. The information content of bank exam ratings and subordinated debt prices. Journal of Money, Credit, and Banking 33, 900-925.

Distinguin I., 2008. Market discipline and bank supervision: the role of subordinated debt. Working Paper, University of Limoges, France.

Ellis, D.M., Flannery, M.J., 1992. Does the Debt Market Assess Large Banks' Risk? Journal of Monetary Economics 30, 481-502.

Evanoff, D.D., Wall, L.D., 2000. A subordinated debt as bank capital: a proposal for regulatory reform. Economic Perspectives, Federal Reserve Bank of Chicago, 40-53.

Evanoff, D.D., Wall, L.D., 2002. Measures of the Riskiness of Banking Organizations: Subordinated Debt Yields, Risk-Based Capital, and Examination Ratings. Journal of Banking and Finance 26, 989-1009.

Evanoff, D.D., Jagtiani, J.A., Nakata, T., 2007. The Potential Role of Subordinated Debt Programs in Enhancing Market Discipline in Banking. Available at SSRN:

http://ssrn.com/abstract=1014057.

Flannery, M.J., Sorescu, S.M., 1996. Evidence of Bank Market Discipline in

Subordinated Debenture Yields: 1983-1991. Journal of Finance 51, 1347-1377.

Flannery, M.J., 2001. The faces of “'market discipline'”. Journal of Financial Services Research 20, 107-119.

Flannery, M.J., Kwan, S., Nimalendran, M., 2004. Market Evidence on the Opaqueness of Banking Firms' Assets. Journal of Financial Economics 71, 419-460.

Flannery, M.J., 2005. No Pain, No Gain? Effecting Market Discipline via Reverse Convertible Debentures. In: Scott, H.S. (Ed.), Capital Adequacy Beyond Basel: Banking Securities and Insurance. Oxford University Press.

Flannery, M.J., 2009. Stabilizing Large Financial Institutions with Contingent Capital Certificates. Working Paper, University of Florida.

French, K.R., et al., 2010. The Squam Lake Report: Fixing the Financial System. Princeton University Press, Princeton, NJ.

Gorton, G., Santomero, A.M., 1990. Market discipline and bank subordinated debt. Journal of Money, Credit, and Banking 22, 119-128. 
Goyal, V., 2005. Market discipline of bank risk: Evidence from subordinated debt contracts. Journal of Financial Intermediation 14, 318-350.

Hart, O., Zingales, L., 2010a. Curbing risk on Wall Street. National Affairs, Spring 2010.

Hart, O., Zingales, L., 2010b. How to make a bank raise equity. Financial Times, February 72010.

Hutchison, D.E., Pennacchi, G.G., 1996. Measuring rents and interest rate risk in imperfect capital markets: the case of retail bank deposits. Journal of Financial and Quantitative Analysis 31, 399-417.

Jagtiani, J., Kaufman, G., Lemieux, C., 2002. The effect of credit risk on bank and bank holding company bond yields: Evidence from the post-FDICIA period. The Journal of Financial Research 25, 559-575.

Jensen, M., Meckling, W., 1976. Theory of the firm: managerial behavior, agency costs, and ownership structure. Journal of Financial Economics 3, 305-360.

Kashyap, A.K., Rajan, R., Stein, J., 2008. Rethinking Capital Regulation. Federal Reserve Bank of Kansas City Symposium, September 2008.

Kaufmann, D., Kraay, A., Mastruzzi, M., 2008. Governance Matters VII: Aggregate and Individual Governance Indicators 1996-2007. World Bank Policy Research Working Paper No. 4654.

Keeley, M.C., 1990. Deposit insurance, risk, and market power in banking. American Economic Review 80, 1183-1200.

Krishnan, C., Ritchken, P., Thomson, J., 2005. Monitoring and controlling bank risk: Does risky debt help? Journal of Finance 60, 343-378.

Krishnan, C., Ritchken, P., Thomson, J., 2006. On Credit-Spread Slopes and Predicting Bank Risk. Journal of Money, Credit, and Banking 38, 1545-1574.

Kwast, M.L., Covitz, D.M., Hancock, D., Houpt, J.V., Adkins, D.V., Barger, N., Bouchard, B., Connolly, J.F., Brady, T.F., English, W.B., Evanoff, D.D., Wall, L.D., 1999. Using subordinated debt as an instrument of market discipline. Report of a study group on subordinated notes and debentures, Board of Governors of the Federal Reserve System, M. Kwast (chair), staff study, No. 172. Available at www.bog.frb.fed.us/pubs/staffstudies/172/default.htm.

Laeven, L., Levine, R., 2009. Bank Governance, Regulation, and Bank Risk Taking. Journal of Financial Economics 93, 259-275. 
Lang, W., Robertson, D., 2002. Analysis of proposals for a minimum subordinated debt requirement. Journal of Economics and Business 54, 115-136.

La Porta, R., Lopez-de-Silanes, F., Shleifer, A., Vishny, R., 1997. Legal Determinants of External Finance. Journal of Finance 52, 1131-1150.

La Porta, R., Lopez-de-Silanes, F., Shleifer, A., Vishny, R., 1998. Law and Finance. Journal of Political Economy 106, 1113-1155.

Levine, R., Zervos, S., 1998. Stock Markets, Banks, and Economic Growth. American Economic Review 88, 537-558.

Levine, R., 2005. Finance and Growth: Theory and Evidence. Handbook of Economic Growth. In: Aghion, P., Durlauf, S. (Eds.), Handbook of Economic Growth. NorthHolland Elsevier Publishers, Amsterdam, pp. 865-934.

Levonian, M., 2000. Subordinated debt and the quality of market discipline in banking. Federal Reserve Bank of San Francisco Working Paper.

Lin, S.L., Penm, J., Gong, S.-C., Chang, C.-S., 2005. Risk-based Capital Adequacy in Assessing on Insolvency Risk and Financial Performances in Taiwan's Banking Industry. Research in International Business and Finance 19, No. 1, 111-153.

Maechler, A., Mitra, S., Worrell, D., 2007. Decomposing Financial Risks and Vulnerabilities in Eastern Europe. International Monetary Fund Working Papers 07/248.

McDonald, R.L., 2010. Contingent Capital with a Dual Price Trigger. Working Paper, Northwestern University.

Morgan, D., 2002. Rating banks: Risk and uncertainty in an opaque industry. American Economic Review 92, 874-888.

Neumark, D., Sharpe, S.A., 1992. Market structure and the nature of price rigidity: evidence from the market for consumer deposits. Quarterly Journal of Economics 107, 657-680.

Niu, J., 2008. Can subordinated debt constrain banks' risk taking? Journal of Banking and Finance 32, 1110-1119.

Pennacchi, G., 2010. A Structural Model of Contingent Bank Capital. Working Paper, University of Illinois.

Pennacchi, G., Vermaelen, T., Wolff, C.C.P., 2010. Contingent Capital: The case for COERCs. Working Paper. 
Petersen, M., 2009. Estimating standard errors in finance panel data sets: Comparing approaches. Review of Financial Studies 22, 435-480.

Poole, W., 2009. Moral Hazard: The Long-Lasting Legacy of Bailouts. Financial Analysts Journal, Nov/Dec, 1-7.

Rauh, J.D., Sufi, A., 2010. Capital Structure and Debt Structure. AFA 2009 San Francisco Meetings Paper. EFA 2008 Athens Meetings Paper. Available at SSRN: http://ssrn.com/abstract=1097577.

Reinhart, C.M., Rogoff, K. S., 2008. Is the 2007 US Sub-prime Financial Crisis So Different? An International Historical Comparison. American Economic Review 98, No. 2, 339-344.

Rochet, J.-C., 2004. Rebalancing the three pillars of Basel II. Federal Reserve Bank of New York Economic Policy Review, 7-21.

Roy, A.D., 1952. Safety First and the Holding of Assets. Econometrica 20, No. 3, 431 449.

Sironi, A., 2003. Testing for market discipline in the European banking industry: Evidence from subordinated debt issues. Journal of Money, Credit and Banking 35, 443472.

Sundaresan, S., Wang, Z., 2010. Design of Contingent Capital with Stock Price Trigger for Conversion. Working Paper, Columbia University.

Thompson, S.B., 2009. Simple Formulas for Standard Errors that Cluster by Both Firm and Time. Available at SSRN: http://ssrn.com/abstract=914002.

Tong, H., Wei, S., 2008. Real effects of the subprime mortgage crisis: is it a demand or a finance shock? IMF and Columbia Business School. Unpublished Working Paper.

U.S. Shadow Financial Regulatory Committee, 2000. Reforming bank capital regulation: a proposal by the U.S. Shadow Regulatory Committee.

Weisbach, M., 1988. Outside directors and CEO turnover. Journal of Financial Economics 20, 431-490. 